\title{
Metamorphic Core Complex dynamics and structural development: Field evidences from the Liaodong Peninsula (China, East Asia)
}

Nicolas CHARLES $S^{1,2,3,4^{*}}$, Charles GUMIAUX ${ }^{1,2,3}$, Romain AUGIER ${ }^{1,2,3}$, Yan CHEN $^{1,2,3}$, Michel FAURE ${ }^{1,2,3}$, Wei LIN $^{5}$, Rixiang ZHU .

1: Université d'Orléans, ISTO, UMR7327 45071, Orléans, France.

2 : CNRS/INSU, ISTO, UMR7327, 45071 Orléans, France.

3 : BRGM, ISTO, UMR7327, BP36009, 45060 Orléans, France.

4: Now at : Bureau de Recherches Géologiques et Minières (BRGM), 3 avenue Claude Guillemin, BP36009, 45060 Orléans, France.

5: Institute of Geology and Geophysics, Chinese Academy of Sciences, Beijing 100029, China.

*Corresponding author: n.charles@ brgm.fr

\begin{abstract}
Metamorphic Core Complexes (MCC) constitute remarkable features within wide rifts. Based on analogue and numerical modelling, MCC dynamics and structural development are mainly controlled by first geothermal gradient, second the compositional layering, and after the strain rate and partial melting. In the Late Mesozoic, continental extension occurred in East Asia leading to the development of MCC, magmatism and extensional sedimentary basins. Based on an integrated study (i.e. structural and finite strain analysis, petrofabrics, Anisotropy of Magnetic Susceptibility (AMS) and U/Pb on zircon
\end{abstract}


dating), this paper aims at constraining the tectonic evolution and deformation mechanisms in the South Liaodong Peninsula (NE China). The Gudaoling massif is identified as a “migmatitic" MCC developed from Upper Jurassic (ca. 157-154Ma) to Early Cretaceous (ca. 128-113Ma). Intrusion of the Yinmawanshan synkinematic pluton (Early Cretaceous) to the south of the dome marks out the final stages of shearing along the Gudaoling detachment zone and of exhumation of the MCC into the upper crust. The Gudaoling MCC and the Yinmawanshan pluton stay in line with the coeval South Liaodong MCC, to the south, all making a $\sim 140 \times 30 \mathrm{~km}$ wide extensional band formed during a regional E-W to NW-SE crustal stretching. The area shows a bi-phased development with a "slow" and a "fast" stage which correspond to (1) crustal necking and (2) dome amplification/exhumation stages according to published thermo-mechanical modelling results. Finally, the Gudaoling MCC lower unit almost exclusively displays migmatites and anatectic granitoids of Late Jurassic and Early Cretaceous, respectively. Occurrence of partial melting during earlier stages of extension seems controlling the initiation of MCC (as a soft anomaly within lower crust). In East Asia, a regional-scale thermal event, during Jurassic-Cretaceous times, may have significantly reduced the bulk lithosphere strength and locally induced partial melting, emphasizing pervasive deformations and development of a wide rift system.

Key-words: continental extension, wide rift, partial melting, MCC development, East Asia, AMS. 


\section{Introduction}

Metamorphic Core Complexes (MCCs) have been firstly defined in the Basin and Range province (USA) and then recognized in the Aegean domain area (e.g. Davis and Coney, 1979; Crittenden et al., 1980; Wernicke, 1981; Lister et al., 1984; Gautier et al., 1990; Sokoutis et al., 1993). MCCs are composed of two main parts: (1) a lower unit made of lower to middle crustal rocks exhumed and deformed during continental extension and (2) an upper unit composed of shallow crustal rocks and characterised by rather localised deformation. The most striking feature of a MCC is the master detachment zone separating the lower and upper units, mainly consisting in a shallow dipping extensional ductile shear zone connecting to mid-crustal levels. Some normal faults usually develop within the upper crust, connecting to the ductile detachment at depth, and control syn-extension sedimentary series deposit. MCC bulk finite architecture thus consists in a dome core composed of high-grade metamorphic rocks, migmatites and granitic plutons surrounded by low-grade metamorphic rocks.

While Buck (1991) defined three modes of extension for continental lithosphere (i.e. narrow rift, wide rift and Core Complex modes), Brun (1999) defined MCC as a particular component of a wide rift system. On one hand, narrow rift displays localised deformation process-at the whole lithosphere scale. This is related to the high strength of uppermost brittle mantle levels (Buck, 1991). Finite deformation extends over rather limited width in that case (50 to $100 \mathrm{~km}$ maximum wide) with significant uprising of the Moho at the base of the rift system (Buck, 1991). On the other hand, wide rift systems are characterised by pervasive extensional processes affecting large areas of the continental crust (several hundreds of kilometres). There, at first order, deformation only localises throughout the thin brittle uppercrust (maximum $\sim 10 \mathrm{~km}$ ) while all the rest of the lithosphere behaves as a ductile medium 
and flows over large volumes; this tectonic phenomenon locally yields to the development of MCCs.

Recently, several numerical and analogue modelling studies focused on the mechanical processes leading to MCCs development and point out, in particular, the predominant role of partial crustal melting (Brun, 1999; Tirel et al., 2006, 2008; Rey et al., 2009a, b). For wide rifts/MCC development, a low viscous lower to middle crust with no brittle layer within upper mantle is required to allow rocks to flow laterally (e.g. Block and Royden, 1990; Buck, 1991; Ranalli, 1997; Brun, 1999). In contrast to continental rifting, a specificity of this tectonic process is to maintain a flat lying Moho geometry while the overall continental crust is thinning. Different first-order parameters control the development of MCCs: (1) the geothermal gradient, (2) the compositional layering (like the thickness of the crust), (3) the strain rate during extension and (4) the presence of an initial "soft" (i.e. low viscosity) rheological anomaly within lower crust (Tirel et al., 2008; Rey et al., 2009a, b). This latter feature could be a local anomaly of high partial melting within the lower crustal levels or magma coming from lowermost crust and/or upper mantle and intruded within the lower crust. In more details, previous studies also point out different possible temporal evolution of MCCs with rapid and slow MCCs (Rey et al., 2009a, b). Several field studies of MCC massifs, combined with accurate time constraint data can characterise the nature of MCC-types (Vanderhaeghe et al., 1999; McGrew et al., 2000; Norlander et al., 2002; Vanderhaeghe et al., 2003; Teyssier et al., 2005; Sullivan and Snoke, 2007; Rey et al., 2009a, b; Charles et al., submitted).

East Asia is marked by large-scale continental extension during late Mesozoic and Cenozoic (e.g. Menzies et al., 1993; Ren et al., 2002; Meng, 2003; Lin and Wang, 2006; Zhai et al., 2007; Charles, 2010; Charles et al., 2011a, b). As no major tectonic event occurred from that time, numerous and various markers of the crustal extension are well preserved. 
Widespread late Mesozoic extensional sedimentary basins are the most studied structures owing to their coal and/or hydrocarbon potentialities (e.g. Liu, 1986; Watson et al., 1987; Ren et al., 2002). Besides, both intrusions and effusions of magmatic rocks are widespread throughout East Asia during late Mesozoic, particularly around 130-120 Ma (e.g. Wang, et al., 1998; Li, 2000; Wu et al., 2000, 2005a, 2005b, 2007). Recently, several Metamorphic Core Complexes (MCCs) have been described in East Asia from Transbaikalia to the Jiaodong Peninsula, 2000 km apart (e.g. Sklyarov et al., 1994; Davis et al., 1996; Webb et al., 1999; Darby et al., 2004; Liu et al., 2005; Lin and Wang, 2006; Donskaya et al., 2008; Daoudene et al., 2009; Charles et al., 2011a). However, while most of the East Asian MCCs exhibit partial melting, with occurrence of migmatites and granitic plutons (Liu et al., 2005; Daoudene et al., 2009, 2011; Charles et al., 2011a), the influence of crustal melting and/or plutonism on tectonic evolution during late Mesozoic remains rarely discussed.

To the north-east of China, the Liaodong Peninsula (Fig. 1) is characterised by a widespread magmatism and continental extension as evidenced by the occurrence of granitic massifs as well as MCC (the South Liaonan MCC: SLMCC) and extensional sedimentary basins (LBGMR, 1994; Liu et al., 2005; Wu et al., 2005a, b; Lin and Wang, 2006; Lin et al., 2007). This study highlights the occurrence of a new major Metamorphic Core Complex, the Gudaoling, to the north of the SLMCC. This and the associated neighbouring granitic massifs - and in particular the Yinmawanshan massif - provide an ideal region to study the link in between partial melting and continental extension in Eastern China. Combining field structural, Anisotropy of Magnetic Susceptibility (AMS) and petrofabrics analyses with U/Pb radiochronology on zircon, this integrated study discriminates field evidences on the role of partial melting for MCC dynamics and structural development. 


\section{Geological setting}

\subsection{The Liaodong Peninsula (East China)}

The Liaodong Peninsula is located in the east of the Liaoning Province of northeastern China. This region belongs to the easternmost part of the North China Block (NCB), along the western margin of the Pacific plate, and is bounded to the west by the NNE-trending crustalscale Tan-Lu fault (Fig. 1a). The study area consists of rocks dated from Archaean to Cenozoic (Fig. 1b). Late Archaean rocks are predominantly composed of tonalitetrondhjemite-granodiorite (TTG) with minor amounts of supracrustal rocks and with $\mathrm{Nd}$ isotopic model ages mainly comprised between 2.8 and 2.5 Ga (Liu et al., 1992; Song et al., 1996). Early Proterozoic rocks of the Liaohe Group consist in sediments and volcanic rocks, metamorphosed during an orogenic event around 1.85 Ga (LBGMR, 1989; Lu et al., 2004). Archaean and Palaeoproterozoic units are unconformably overlaid by sediments: (1) Neoproterozoic (Sinian) strata composed of shale, sandstone, limestone and dolomite, (2) Palaeozoic layers comprising a suite of marine sedimentary rocks and (3) half-graben Cretaceous basins which are infilled by continental sediments and volcanic rocks (e.g. Wafangdian basin in Fig. 1b; Allen et al., 1997; Ren et al., 2002; Liu et al., 2005). Furthermore, Mesozoic granitoids are widely distributed throughout the Liaodong Peninsula, covering an area estimated at ca. 20,000 km² (LBGMR, 1989; Wu et al., 2005a, b) and spanning from Late Triassic to Early Cretaceous (Wu et al., 2005a, b; Yang et al., 2007c). Several regional-scale structures, such as the South Liaonan Metamorphic Core Complex (SLMCC; 120-110 Ma; Yin et Nie, 1996; Liu et al., 2005; Lin and Wang, 2006, Yang et al., 2007b; Lin et al., 2008), the Yiwulüshan dome (116 Ma; Darby et al., 2004), the Laohushan synkinematic pluton (122 Ma; Lin et al., 2007) and the Songliao basin (Ren et al., 2002; Lin et al., 2003) are diagnostic of an important crustal extension during Early Cretaceous. 
The latest event in the area is marked by the eruption of alkali basalt, with occurrence of xenoliths, during Cenozoic (LBGMR, 1989; Griffin et al., 1998). This work focuses on the southeastern part of the Liaodong Peninsula: the Gudaoling and Yinmawanshan massifs which are currently recognised as a large-scale magmatic complex.

2.2. A 'giant' extensional complex in the South Liaodong?

The South Liaonan Metamorphic Core Complex (SLMCC) has first been identified by $\mathrm{Xu}$ et al. (1991) and LBGMR (1994). It is located in the southernmost tip of the Liaodong Peninsula and extends over $50 \mathrm{~km}$ along a NNE direction (Fig. 1b). The SLMCC is mainly composed of migmatites (presumably Archaean in age) and of Jurassic to Cretaceous granitoids. Structural studies highlight a pervasive ductile deformation throughout the massif with evidence of high-strain zone along its western edge (Liu et al., 2005; Lin and Wang, 2006; Lin et al., 2007, 2008). Considering radiochronological data (Wu et al., 2005a, b ; Lin et al., 2007 ; Yang et al., 2008) one can conclude to a rather fast exhumation of the dome, below a west verging extensional detachment, during Early Cretaceous (120-110 Ma).

To the North, the Yinmawanshan and Gudaoling massifs align with the SLMCC (Fig. 1b). Both massifs are often presented as Cretaceous igneous intrusions (Wu et al., 2005a, b). However, structural data on both internal deformation and relationship of these massifs with the surrounding rock units is lacking and the timing of the Mesozoic extension/magmatism is only partly constrained in this area.

This paper presents a multidisciplinary approach where finite strain is studied using both (1) classical structural analysis and (2) Anisotropy of Magnetic Susceptibility (AMS) analysis for intrusive bodies where macroscopic finite strain cannot be evidenced. In addition, timing and strain rate are constrained by new $\mathrm{U} / \mathrm{Pb}$ zircon analyses combined with a 
compilation of existing radiochronological data. This study highlights spatial prolongation of the SLMCC structures to the north; as a whole this $\sim 150 \mathrm{~km}$ long structure can thus be considered as a particularly large specimen of extensional complex in the continental crust. These results also highlight a well-defined MCC where the entire tectonic evolution and timing can be constrained, from the extension initiation (in the deepest part of the crust), through the exhumation of the dome (within upper crust) and up to the dating of the latest deformation increments along the master detachment.

\section{The Gudaoling Metamorphic Core Complex}

Located between Huatong and Wanfu cities, and to the south of Gaizhou, the Gudaoling massif forms a N-S oriented relief. It is aligned with the SLMCC, to the north, with a 50 by $30 \mathrm{~km}$ spatial extent. As a whole, the Gudaoling massif (see "GD” on Fig. 1b) is made of granitic rocks inter-fingered and emplaced within high-grade metamorphic rocks and in particular migmatites. As detailed below, the present study shows that the Gudaoling massif must be regarded as a Metamorphic Core Complex (MCC). It includes migmatites and granitoids, in the lower unit, separated from the "upper unit" by an extensional master detachment zone to the east.

\subsection{Surrounding rocks: the Upper unit}

As shown on Fig. 2, the Gudaoling massif is surrounded by Late Archaean, Early Proterozoic, Neoproterozoic (Sinian) rocks that formed the upper crust of the area at the onset of late Mesozoic extension. In the field, Late Archaean rocks mainly consist of migmatites, gneiss, micaschists with several amphibolite boudins that are particularly well exposed close 
to the Anbo city and to the west of the Gudaoling massif (Fig. 2). Gneissic and migmatitic structuration is Precambrian in age (LBGMR, 1994). Early Proterozoic units extend to the north-northeast of the massif (Fig. 2). They include low-grade metasedimentary rocks including quartzites, metasilts and micaschists. Approaching the Gudaoling eastern border, the micaschists exhibit a well-marked deformation, with the development of protomylonitic foliation developed at the expense of older fabrics, drag folds and a conspicuous $\sim$ N090plunging stretching lineation (underlined by white micas). Granitic veins sometimes injected into the foliation plane. Sinian, Neoproterozoic sedimentary rocks displaying variable metamorphic grades unconformably lay on top of the Precambrian rocks described above. These metasedimentary rocks consist in W-dipping marbles, red monogenic conglomerates, dark greenish quartzites and siltites outcropping to the west and to the southeast of the Gudaoling massif (Fig. 2). Within a $\sim 100 \mathrm{~m}$ wide band along the eastern border of the massif, Neoproterozoic (Sinian) dark greenish quartzites display higher strain.

Finally, Cretaceous rocks cropping out in narrow N-S sedimentary basin, are made of volcanic rocks (e.g. andesite, trachyandesite) intercalated into scarce red conglomerates and sandstone series. They are confined along both Western and Eastern borders of the massif, close to Lutun and Wanfu cities (Fig. 2).

\subsection{Rocks of the dome: the Lower unit}

Crystalline rocks of the metamorphic core include migmatite (Fig. 3a) intruded by successive pulses of Early Cretaceous igneous rocks (Wu et al., 2005a, b; 1: quartz diorite, 2: porphyric granodiorite and 3: fine-grained grey monzogranite; Figs. 3b and 4). Migmatites exhibit well-developed metatexites displaying leucosomes and melanosomes layering (Fig. 3a). In some places, lithological layering of the migmatites displays as parallel surfaces, 
concordant with the foliation, while in other places it shows disorganised, curved layers (Fig. 3a). Amphibolite layers and boudins are often observed as intercalations within migmatite (Fig. 3a). All the metamorphic units found within the Gudaoling massif show a significant partial melting and sometimes laterally evolve to diatexites and anatectic granites, with lithological contrasts and migmatitic structures preserved in situ (Fig. 3c). Migmatites yield a $157 \pm 3 \mathrm{Ma} \mathrm{U} / \mathrm{Pb}$ age on zircon, along the massif eastern border (Wu et al., 2005b). For other parts, and in particular within the core, no other dating is available and, until now, a Precambrian age is invoked (LBGMR, 1972, 1974).

Intruded within this migmatitic unit, different granitic rocks have also been described across the Gudaoling massif, often leading to regard this massif ene as a pluton. Hitherto, these rocks have mostly been studied to determine their petrography, geochemistry and age (Yang et al., 2004, Wu et al., 2005a, b; Yang et al., 2007a, 2008). Intrusions mainly consist in monzogranite (with numerous enclaves), with some quartz diorite located in the centre of the massif and porphyric granodiorite confined to the north of Anbo city (Fig. 2). Monzogranite is a fine-grained grey rock composed of plagioclase, alkali-feldspar, quartz and biotite, \pm hornblende. Accessory minerals include apatite, zircon, titanite and Fe-Ti oxides (Yang et al., 2004). Quartz diorite exhibits a rather weak mineral orientation, with an assemblage of quartz, plagioclase and hornblende, $\pm \mathrm{K}$-feldspar and biotite. Porphyric granodiorite is medium- to coarse-grained with hypidiomorph inequigranular textures. Mineralogical assemblage consists in quartz, plagioclase, K-feldspar, biotite and hornblende with accessory iron oxides. Monzogranite, porphyric granodiorite and quartz diorite have been dated at $121 \pm 1$ to $118 \pm 3$ Ma, $124 \pm 2 \mathrm{Ma}$ and $127 \pm 4 \mathrm{Ma}$, respectively (U/Pb on zircon; Fig. 2; Wu et al., 2005a). Besides, ${ }^{40} \mathrm{Ar} /{ }^{39} \mathrm{Ar}$ datings have been performed on monzogranite yielding $116 \pm 3 \mathrm{Ma}$ for hornblende, $113 \pm 2$ Ma for biotite, and on quartz diorite with $118 \pm 3$ Ma for hornblende and $112 \pm 2$ Ma for biotite (Fig. 2; Yang et al., 2008). From a geochemist point of view, 
monzogranite have low initial ${ }^{87} \mathrm{Sr} /{ }^{86} \mathrm{Sr}$ ratios $(0.7052-0.7086)$ and strongly negative $\varepsilon_{\mathrm{Nd}}(\mathrm{t})$ values (-18.5 to -20.9$)$ leading to consider a crustal origin for these magmas (Yang et al., 2004). In contrast, the enclaves which yield consistent $120 \pm 1$ Ma crystallisation ages (U/Pb on zircon; Yang et al., 2007a) are characterised by higher $\varepsilon_{\mathrm{Nd}}(\mathrm{t})$ values (+4.5 to -6.2$)$, low initial ${ }^{87} \mathrm{Sr} /{ }^{86} \mathrm{Sr}$ ratios $(0.7058-0.7073)$ and are enriched in light rare earth elements (LREE) and large ion lithophile elements (LILE). This suggests that part of the magmas were also derived from an enriched lithospheric mantle source (Yang et al., 2004, 2007a). Bimodal melt sources (crust and upper mantle) and magma mixing must be considered for the origin of granitic rocks in the Gudaoling massif.

\subsection{Overall structures of the dome and the Gudaoling detachment fault (GDF)}

Our field observations show that, most of the time, migmatites are intercalating with the fine-grained grey monzogranite. At outcrop-scale, granite can be observed both as interfingered bodies into migmatitic layers or as cross-cutting dykes (Fig. 3b and 3c). At cartographic-scale, $\sim 1 \mathrm{~km}$, occurrences of both lithologies can be alternatively observed. From this, a coherent monzogranite pluton could not be individualised into the Gudaoling massif. Outlines of the monzogranite/migmatite cannot be strictly drawn at the scale of our study and a "composite" migmatites/anatectic granite/monzogranite unit is considered here (see "migmatites/monzogranite" on Fig. 2). Yet, relative proportion of these lithological facies can spatially change within the Lower unit. In particular, the eastern border and the south-eastern corner of the massif display migmatites, exclusively, (Fig. 2). In turn, quartz diorite rocks form a curved band of up to $\sim 5 \mathrm{~km}$ width which crosses the massif (Fig. 2). The porphyritic granodiorite lies in its SSW part, in contact with the Archaean migmatites of the surrounding rocks, close to Anbo city (Fig. 2). 
To the west of the Gudaoling, migmatites display a rather disorganised layering and the associated Early Cretaceous monzogranite is isotropic. Both become progressively deformed toward the NW as shown by the gradual development of N030-trending and NWdipping foliation planes. An associated E-W mineral and stretching lineation is also observed which is underlined by biotite and quartz (Fig. 2). Along the western border, shear bands obliquity with regard to foliation plane orientation shows a top-to-the $\mathrm{W}$ simple shear deformation regime (Fig. 2). Migmatites outcropping in the SW of the massif (between granodiorite and monzogranite bands) exhibits a W-dipping foliation accompanied by stretching lineation. In contrast, drag folds and other kinematic markers indicate a top-to-the E sense of shear (Figs. 2 and 3d).

In the core of the massif, the prominent quartz diorite displays a shallow dipping foliation, with dip switching from $\mathrm{W}$ to $\mathrm{E}$, and an orientation parallel to the fabric in the neighbouring migmatites (Fig. 2). On the other hand, the fine-grained grey monzogranite is isotropic in the centre of the massif, with preserved magmatic fabrics (e.g. schlierens). Moreover, no planar or linear mineral preferred orientation could be macroscopically observed.

The eastern boundary of the Gudaoling is marked by particularly strong finite strain, whatever the rocks considered, which gradually increases from the core toward this border. There, initial migmatitic layering is sometimes completely transposed. Particularly welldeveloped mylonitic foliation strikes $\sim \mathrm{N}-\mathrm{S}$, parallel to the N-S striking envelope of the massif. This mylonitic foliation dips 15 to $35^{\circ}$ to the east, in opposite direction compared to the western border. Internal fabric of the Gudaoling thus defines a dome shape. Stretching lineation, underlined by biotite, quartz aggregates and stretched amphiboles display a consistent N090-N120E trend (Figs. 2 and 4). At outcrop-scale, low-angle E-dipping foliation displays sigmoid, drag folds, $\sigma$ - and $\delta$-pressure shadows around feldspars and associated shear 
planes showing a clear simple shear deformation regime characterised by a top-to-the E sense of shear (Figs. 2, 3e, 3f and 4). From west to east, shear bands become more numerous and thicker (from few millimetres to centimetres), defining a map-scale mylonitic band running along the eastern edge of the massif. Well-developed ultramylonitic rocks are encountered to the top of the lower unit rocks of the dome (Fig. 4). Fabric in both granitic and migmatitic rocks exhibit impressive flagstones forming local reliefs in the landscape (Fig. 3g). Microstructural observations within this mylonitic band confirm the intense finite strain. It is expressed as plastic deformation and solid-state flow associated to top-to-the E kinematics, as shown by mica-fish geometries (e.g. Fig. 3h), $\delta$ - or $\sigma$-type porphyroclast, shear bands and asymmetrical pressure shadows around hard resistant minerals (see Passchier and Trouw, 2005).

Finally, thickness of the N-striking ductile shear zone, along the eastern border of the Gudaoling dome, can be estimated at $3-4 \mathrm{~km}$, including $1-1.5 \mathrm{~km}$ of mylonites to ultramylonites. Deformed eastern border of the dome describes a low-angle sharp limit area between a high-grade lower unit, in the core of the dome, and a low-grade or earlier metamorphosed upper unit through a major extensional shear zone characterised by both ductile flow and subsequent movements under brittle conditions (Fig. 4). Indeed, at the top of this ductile shear zone (i.e. to the east) some tectonic breccias are observed with clasts of sandstones, micaschists and greenish quartzites from Precambrian upper units and some granitic and metamorphic mylonitic rocks from the lower unit (Figs. 4 and 5a).

As a result, the eastern border of the Gudaoling dome can be considered as a master detachment fault with top-to-the E sense of shear, that we called the Gudaoling detachment fault (GDF; Figs. 2 and 4). All the structural features described above fit well with those characterising well-known MCCs in the Basin and Range province (e.g. Davis and Coney, 1979; Crittenden, 1980; Wernicke, 1981; Lister and Davis, 1989), and in the Aegean domain 
(e.g. Lister et al., 1984; Gautier et al., 1993; Wawrzenitz and Krohe, 1998; Jolivet et al., 2004) and East Asia areas (e.g. Davis et al., 1996; Liu et al., 2005; Lin and Wang, 2006; Daoudene et al., 2009, 2011; Charles et al., 2011a). The Gudaoling dome can thus be defined as a MCC exhumed below a master detachment fault.

\subsection{The Cretaceous extensional basins}

East of the Gudaoling MCC, near Wanfu city, a Cretaceous sedimentary basin extends along the GDF (over $\sim 160 \mathrm{~km}^{2}$ ) and unconformably overlies Archaean and Proterozoic rocks of the upper unit of the MCC (Fig. 2; LBGMR, 1972, 1974). Clastic sedimentary rocks comprise red sandstone with a few conglomerate layers (Fig. 5b). Bedding generally trends $\sim \mathrm{N}-\mathrm{S}$ and dips towards the west (ca. $30^{\circ}$ to $50^{\circ}$ ). Large volume of andesitic lava and volcanic breccias is also intercalated within sedimentary deposits (Fig. 5c). While the basin itself displays low reliefs and relative poor outcropping conditions, the transition zone from the metamorphic units of the Gudaoling MCC to the basin is well exposed and has been extensively studied. The Gudaoling detachment fault includes both ductile and brittle structures (see Section 3.3), at the base and at the top of the detachment fault, respectively. Besides, rocks of the upper unit are sometimes observed between the mylonites roofing the dome and the basin (see NW and SW of the basin, Fig. 2a) and the western limit of the Wanfu Cretaceous deposits is marked by steep normal faults. In addition, west dipping normal faults also developed pervasively within the volcano-sedimentary series itself; the major ones separating blocks into the basin. Note that no intersection of the normal faults with below lying mylonites has been observed. On the contrary, the high-angle brittle structures seem to connect to the low-angle ductile shear zone. All these structures lead us to interpret the "Wanfu" Cretaceous basin as a half-graben lying on the hanging wall of the Gudaoling 
MCC (Fig. 4). Structural relationships between mylonites and brittle faults as well as their shared E-W extensional regime argue for a coeval development of the extensional basin and the GDF. However, radiometric dating of the volcanic units in the basin is needed to unambiguously establish this synchronism.

It is noteworthy that, on the northwestern border of the Gudaoling MCC (see Lutun city) scarce outcrops of sedimentary strata and volcanic breccias are observed. These series display similar lithologies as the one in the "Wanfu" basin and strata display a moderate Wdipping (Figs. 2 and 5d; LBGMR, 1974). These rocks most probably pertain to a Cretaceous basin in the northwestern part of the Gudaoling MCC (Fig. 2; LBGMR, 1974) but, due to Cenozoic cover, no direct relationship between these series and the dome could be observed. Field structural observations along the western border of the dome highlight a clear top-tothe-W sense of shear (Fig. 2), consistent with a plausible secondary detachment fault.

\section{The Mesozoic intrusions}

In addition to the anatectic rocks closely associated with the migmatites of the Gudaoling MCC, several granitic plutons emplaced throughout the study area, during Late Mesozoic times. These have been mostly dated to Early Cretaceous ( 120-128 Ma; Figs. 1b and 2; Wu et al., 2005a, b). In the field, they intruded into upper crustal levels, within the Precambrian rocks of the upper unit. One pluton in particular, forming the large Yinmawanshan massif, is subject to a specific attention in this study.

\subsection{The Yinmawanshan pluton}

\subsubsection{Lithology}


The Yinmawanshan pluton is located between the South Liaodong MCC (e.g. Liu et al., 2005) and the newly identified Gudaoling MCC, east of Wafangdian city. It draws a $\sim 40 \mathrm{x}$ $\sim 30 \mathrm{~km}$ E-W elongated ellipse in map view (see "YM" on Figs. 1b and 2; LBGMR, 1972). It is mainly composed of two distinct lithologies, from rim to the core: (1) porphyritic granodiorite with K-feldspar megacrysts, quartz, biotite and hornblende, and (2) fine-grained monzogranite with quartz, biotite, K-feldspar \pm hornblende (Figs. 2 and 6a; LBGMR, 1972; Guo et al., 2004). Yet, both rock types yield similar U/Pb on zircon ages with $129 \pm 2$ to 120 $\pm 4 \mathrm{Ma}$ and $124 \pm 5$ to $122 \pm 6 \mathrm{Ma}$ for the porphyric granodiorite and medium- to fine-grained monzogranite, respectively (Fig. 2; Guo et al., 2004; Wu et al., 2005a). ${ }^{87} \mathrm{Sr} /{ }^{86} \mathrm{Sr}$ ratios are ranging from 0.708772 to 0.713501 with lower values for medium to fine-grained monzogranite, and negative $\varepsilon_{\mathrm{Nd}}(\mathrm{t})$ values (-19.32 to -14.62). Consequently, the source of the Yinmawanshan intrusion mainly derived from ancient lower crust with a significant contribution of lithospheric mantle and juvenile crustal components (Guo et al., 2004). In contrast with the Gudaoling MCC, the Yinmawanshan pluton is exclusively composed of granitic rocks devoid of migmatites and only rare xenoliths.

\subsubsection{Structure of the Yinmawanshan pluton}

Structural field observations in the Yinmawanshan pluton are illustrated in Figure 6. Both the western and central parts of the massif exhibit subsolidus fabrics (Figs. 6a and 6b) with figures of magmatic flow, as evidenced by schlierens. On the southern border, aplitic dykes intruded into the Late Archaean migmatites (Fig. 6c). To the west, the geological outline of the massif forms peculiar curved shapes (Fig. 7). According to the geological map and our field structural study, this geometry is locally controlled by the north striking subvertical Neoproterozoic (Sinian) sedimentary series (Figs. 2 and 7). One particular thick 
quartzite layer, with $>80^{\circ}$ westward dip, follows the contact with the igneous rocks there. To the north of the massif, external contact and apophyses of the isotropic granodiorite cut across rocks and ductile fabric of the Gudaoling MCC. All these features clearly argue for intrusion of the Yinmawanshan igneous rocks within both the Precambrian rocks of the upper unit and the exhumed metamorphic rocks of the Gudaoling MCC. Finally, the Yinmawanshan granitic rocks contain few xenoliths of the Gudaoling MCC rocks, which is consistent with the above described structural relationships. Yet, apophyses of the Cretaceous intrusive rocks of the MCC cross-cutting the external lithological facies of the Yinmawanshan massif have also been observed. This suggests a contemporaneous or sub-contemporaneous emplacement time for the Yinmawanshan massif and the granites included within the Gudaoling dome. This inference is corroborated by a similar Early Cretaceous U/Pb ages on zircon at 118 to $129 \mathrm{Ma}$ for both geological features (Fig. 2; Guo et al., 2004; Wu et al., 2005a, b).

Contrasting with the rest of the massif, the north-eastern border of the Yinmawanshan pluton displays strained rocks as underlined by a progressive development of NE-dipping foliation (Fig. 6a) and an associated stretching lineation, marked by quartz aggregates, biotite and stretched amphibole (Fig. 2). Stretching direction spans from N090 to N115E over the deformed zone, which is consistent with the deformation observed all along the Gudaoling detachment fault. Moving to the east, C/S structures gradually affect granitic rocks (Fig. 6d), with a decrease in both grain-size and C/S angles (Figs. 6a, 6b and 6c). Kinematics analysis (e.g. asymmetric pressure shadows and C/S obliquity) shows a systematic top-to-the E sense of shear along the north-eastern border. Tectonic breccias developed at the expense of both the mylonite and surrounding rock clasts, argue for a superimposed localised brittle deformation along this structure (Fig. 6e).

Deformation along the north-eastern border of the Yinmawanshan pluton within a cartographic band of $\sim 4 \mathrm{~km}$ gradient of finite strain, reaching mylonitic stage along the 
contact (Figs. 2 and 6a). Deformed rocks are only confined to the Yinmawanshan pluton itself as the surrounding rocks (i.e. Late Archaean and Neoproterozoic units) do not display ductile strain. In details, the deformed zone displays two distinct branches, which merge to the north (Fig. 2). One corresponds to the southern extension of the Gudaoling detachment fault and the other is localised along the north-eastern external boundary of the pluton. Toward the south, in the strike of the GDF, deformation then progressively decreases and disappears. This ductile shear zone thus laterally dies out into the pluton, with a drastic reduction of the net movement (Fig. 2).

To sum up, the Yinmawanshan pluton is solely made of monzogranite and porphyric granodiorite with neither migmatite nor anatexite. Intrusive relationships with surrounding rocks have been evidenced the progressive development of $\mathrm{C} / \mathrm{S}$ structures to the northeast of the massif is diagnostic of a synkinematic emplacement (Berthé et al., 1979). Thus, the Yinmawanshan pluton can be regarded as a synkinematic intrusion emplaced within upper crustal levels during at least partly ductile shearing along the Gudaoling detachment fault.

\subsection{Others plutons of the upper unit}

Three distinct granitic plutons outcrop to the east of the Gudaoling MCC (Figs. 1 and 2). While the smallest of these massifs display an elliptic east trending shape, the two others rather display contorted outlines in map view, with no particular preferred orientation (Fig. 1). Previous $\mathrm{U} / \mathrm{Pb}$ analyses on zircon yielded $120 \pm 2$ to $128 \pm 3$ Ma crystallisation ages for the Zhuanghe pluton, the largest, north of Zhuanghe city (Fig. 1 and references therein). According to our field structural study, granitic rocks of these plutons look unstrained, at least from a ductile point of view. Contacts with the surrounding Precambrian rocks systematically show intrusive relationships with, in particular, (1) xenoliths preserved into the granitoids and 
(2) development of metamorphic contact aureoles (e.g. metaquartzites into Neoproterozoic Sinian - sedimentary series). These granitic bodies can be defined as plutons intruded into Precambrian rocks of the upper unit, during Early Cretaceous.

Based on field observations together with published geological maps (LBGMR, 1972, 1974), the Zhuanghe pluton can be regarded as the eastern prolongation of the Yinmawanshan pluton. Indeed, both massifs share (1) similar porphyritic granodiorite lithologies (see Fig. 2), (2) similar surrounding rock units (and, most probably, similar emplacement level) and (3) similar emplacement ages (129-120 Ma and 128-120 Ma for the Yinmawanshan and the Zhuanghe pluton, respectively). Yet, ductile shearing observed along the NE edge of the Yinmawanshan pluton does not extent further south into the Zhuanghe pluton or along its external boundary even (Fig. 2).

\section{Petrofabrics and AMS studies of the late intrusions}

Isotropic granitic rocks have been observed both as plutons within the Precambrian rocks of the upper unit (e.g. Yinmawanshan, Zhuanghe plutons) but also as intrusions within the migmatites of the Gudaoling MCC (see fine-grained grey monzogranite, in particular). However, even if finite strain is not macroscopically expressed and can thus not be directly studied in the field, microstructural analysis and measurement of minerals statistical preferred orientation is necessary if one wants to highlight the potential incremental strain conditions during granitic rocks crystallisation. Combined with microstructures and petrofabric analyses, an Anisotropy of Magnetic Susceptibility (AMS) study has been performed on samples from the Yinmawanshan pluton as well as from granodiorites of the Gudaoling MCC. In particular, measurement of planar and linear magnetic fabrics should permit to better constrain strain 
field and bulk structure of the interfingered monzogranite/migmatite unit within the Gudaoling MCC.

\subsection{Microstructures and petrofabric analyses}

Description of microstructures is often used to define magmatic or solid-state flow in granitic rocks (e.g. Gapais and Barbarin, 1986; Hibbard, 1987; Paterson et al., 1989; Vernon, 2000; Passchier and Trouw, 2005) and thus allows determining the rheological state of a rock during tectonic and/or magmatic event. Using optical microscope, detailed analyses of 78 thin-sections (49 for anatectic granitoids within the Gudaoling MCC and 29 for the Yinmawanshan intrusion), result in the identification of four different types of microstructures (Figs. 8 and 9), with increasing strain amount: (1) magmatic microstructure, (2) weak solidstate fabric, (3) moderate solid-state fabric and (4) intense solid-state fabric. Details on these petrofabrics and characteristics of the microstructures are given in Appendix A.

In order to accurately highlight potential lateral strain gradients throughout the massifs, the samples have been collected across both granitic parts of the Gudaoling MCC and the Yinmawanshan pluton. Spatial distribution of the four microstructure types is shown

\section{in Figure 9:}

- In the Gudaoling MCC, magmatic and weak solid-state microstructure types together account for over $70 \%$ of the samples and, thus, of the dome surface (Fig. 9). They rather occupy the central part of the dome and conversely this type has not been found along the eastern border of the MCC. These microstructures do not define any clear spatial organisation (Fig. 9). In turn, moderate solid-state fabrics represent about $15 \%$ of the samples. Such a fabric type is located (1) along the eastern border of the massif, (2) on its northwestern edge and (3) in the area displaying an alternation of dioritic and migmatitic 
rock "bands", in the SE part of the dome (Figs. 2 and 9). Finally, intense solid-state fabrics which correspond to mylonitic to ultramylonitic rocks represent $15 \%$ of the samples and are exclusively distributed along the MCC eastern border, in close association with the Gudaoling detachment fault (GDF; Figs. 2 and 9).

- In the Yinmawanshan pluton, samples with magmatic and weak solid-state flow evidences occupy more than $75 \%$ of the pluton surface (Fig. 9). Samples displaying moderate to intense solid-state fabric types are only restricted to the northeastern border of the pluton, along a $\sim 5 \mathrm{~km}$ wide, NW to NNW striking band (Fig. 9). The Yinmawanshan pluton thus generally displays very limited finite strain except at the vicinity of the GDF where clear solid-state flow evidences appear.

\subsection{Anisotropy of magnetic susceptibility study}

As shown in the pioneer paper of Graham (1954), the Anisotropy of Magnetic Susceptibility (AMS) is a powerful tool for analysing, in particular, structure orientation when finite strain is macroscopically not well expressed. Besides, AMS is a versatile method for analysing both qualitatively and quantitatively the magmatic and solid-state fabric of granitic rocks (e.g. Hrouda, 1982; Rochette et al., 1992; Borradaile and Henry, 1997; Bouchez, 1997; Talbot et al., 2004; Charles et al., 2009; Joly et al., 2009; Denèle et al., 2011). 708 cores from 78 sample sites have been studied for the Early Cretaceous anatectic granitoids emplaced into the Gudaoling MCC and 403 cores from 50 sample sites have been studied for the two granitic facies of the Early Cretaceous Yinmawanshan pluton (Tables 1 and 2). Most outcrops in those granitic rocks are fresh and cores samples are not macroscopically weathered below a few millimetres from the surface. See Appendix B for details on sampling and laboratory measurements procedure. 


\subsubsection{Magnetic mineralogy}

Characterisation of magnetic minerals carrying magnetic susceptibility has to be performed to understand the relationships between mineral grains shapes and their spatial distribution, with rock fabrics (ex. Rochette et al., 1992; Tarling and Hrouda, 1993). Figure 10 shows the distribution of the bulk magnetic susceptibility values measured from granitic rocks of the Gudaoling dome (in black colour) and Yinmawanshan pluton (in white colour):

- For the anatectic granitoids of the Gudaoling MCC, more than $70 \%$ of cores reveal a weak magnetic susceptibility of $<500 \times 10^{-6} \mathrm{SI}$, reflecting typical paramagnetic minerals (Fig. 10) and which are considered as main carrier of magnetic susceptibility in granitic rocks (Bouchez, 1997, 2000). The remaining 30\% exhibit higher values of magnetic susceptibilities (from 2000 to $28000 \times 10^{-6} \mathrm{SI}$ ) revealing the presence of ferromagnetic minerals as main carrier (Fig. 10; Bouchez, 1997, 2000).

- In the Yinmawanshan pluton, more than $85 \%$ of the cores display a high susceptibility value of $>500$ up to $14000 \times 10^{-6}$ SI (Fig. 10), showing ferromagnetic minerals as main carriers of magnetic susceptibility.

Note that, for both massifs, the distribution of bulk susceptibility is not spatially controlled. As a result, the magnetic fabrics are subject to a uniform interpretation for the entire Gudaoling MCC and Yinmawanshan pluton.

Hysteresis loops for granitic rocks of the Gudaoling MCC reveal two different behaviours (Figs. 11a and 11b). Figure 11a displays a linear relationship between induced magnetic moment and applied magnetic field, showing the presence of paramagnetic minerals. Conversely, Figure 11b exhibits a typical loop shape for multidomain ferromagnetic minerals (Dunlop and Özdemir, 1997), with a high value of induced magnetic 
moment reaching $>400 \times 10^{-3} \mathrm{Am}^{2} / \mathrm{kg}$. For the Yinmawanshan pluton, hysteresis cycle shows the occurrence of multidomain ferromagnetic minerals, with a relatively high value of induced magnetic field of $>200 \times 10^{-3} \mathrm{Am}^{2} / \mathrm{kg}$ (Fig. 11c). Considering IRM measurements, granitic rocks of the Gudaoling MCC display hard and soft coercitive minerals (Figs. 11d and 11e, respectively). The high $(6.2 \mathrm{~A} / \mathrm{m})$ and rather low $\left(3.3 \times 10^{-2} \mathrm{~A} / \mathrm{m}\right)$ magnetic moment values imply occurrences of ferromagnetic and paramagnetic minerals, sustaining bulk magnetic susceptibility and hysteresis loops results. IRM measurements for the Yinmawanshan pluton indicate that specimen is saturated more than $80 \%$ at $200 \mathrm{mT}$ (Fig. 11f), leading to consider high ferromagnetic minerals contents. Finally, thermal magnetic (Curie) measurement for granitic rocks of the Gudaoling MCC show magnetic susceptibility dropping at around 350 and $580^{\circ} \mathrm{C}$ revealing presence of maghemite and magnetite, respectively (Fig. 11g). However, the low value of natural magnetic susceptibility $\mathrm{K}_{0}\left(3.4 \times 10^{-6} \mathrm{SI}\right)$ and linear relationship between magnetic susceptibility and temperature, for the heating stage of KG177-104 sample, involve occurrence of paramagnetic minerals (Fig. 11h). For the Yinmawanshan pluton, Figure 11i clearly shows a magnetic susceptibility value dropping at around 350 and $580^{\circ} \mathrm{C}$ which corresponds to maghemite and magnetite occurrences in the granitic rocks. Backscattered electron images confirm presence of multidomain magnetite in both massifs granitic rocks with grain size $>50 \mu \mathrm{m}($ Fig. 11j).

To sum up, granitic rocks of the Gudaoling MCC include soft coercitive minerals such as multidomain magnetite, and paramagnetic ones characterised by phyllosilicates (i.e. biotite). These rocks have thus a bimodal magnetic mineralogy dominated by either magnetite or biotite depending on sampling place in the massif (Bouchez, 1997, 2000). Fortunately, biotite and magnetite subfabrics orientations exhibit no significant variations (Archanjo et al., 1995). On the other hand, the Yinmawanshan pluton can be considered as a ferromagnetic granite (Bouchez, 1997, 2000) with magnetite as the main carrier of the magnetic 
susceptibility. Magnetic interactions between magnetite grains are negligible as shown by Grégoire et al. (1995, 1998), which made AMS measurements consistent. Moreover, no inverse magnetic fabrics are expected due to multidomain magnetite grain size $>50 \mu \mathrm{m}$ (Rochette et al., 1992; Tarling and Hrouda, 1993).

\subsubsection{Magnetic fabrics of anatectic granitoids from the Gudaoling MCC}

Granitic rocks have been analysed in the laboratory in order to measure their planar and linear magnetic fabrics. Statistics on these measurements are presented in Table $\mathbf{1 .}$ Sampled sites showing a corrected anisotropy degree $\left(\mathrm{P}_{\mathrm{J}}\right)$ higher than $20 \%$, represent more than $20 \%$ of all sites (Table 1). This proportion is the same for sampled cores as shown in Fig. 12a. Weak $\mathrm{P}_{\mathrm{J}}$ value for the majority of samples $(80 \%)$ indicates that studied granitic rocks have probably not encountered significant deformations from the AMS acquisition period. This corroborates dominant magmatic microstructures as deduced from the above described petrofabric analysis. The AMS foliation is statistically better defined than the lineation since more than $80 \%$ of samples have a shape parameter of AMS (T) value higher than 0 (Table 1 and Fig. 12a and 12b). However, magnetic lineations present a well-defined distribution since only 9 sites out of 78 (e.g. Sites 218, 230, 233) exhibit a confidence level $\left(\alpha_{95}\right.$ mean) values higher than $20^{\circ}$ (Table 1). Figs. 12b and 12c confirm bimodal magnetic mineralogy for granitic rocks of the Gudaoling MCC with samples cluster close to $\mathrm{K}_{\mathrm{m}}$ low values, and more scattered samples with $\mathrm{K}_{\mathrm{m}}$ values $>2000 \times 10^{-6}$ SI. No statistically reliable relationship can be established between the corrected anisotropy degree $\left(\mathrm{P}_{\mathrm{J}}\right)$ and shape parameter (T) value, neither with the bulk magnetic susceptibility $\left(\mathrm{K}_{\mathrm{m}}\right.$; Figs. 12b and 12c).

AMS principal axes $\left(\mathrm{K}_{1}\right.$ and $\left.\mathrm{K}_{3}\right)$ are presented in equal-area projection for each site of the Gudaoling MCC with sampling locations (Fig. 13). The AMS site-mean directions 
measured in the Gudaoling MCC granitic rocks are represented as a structural map in Figure 14. Magnetic foliations strike globally N-S to NNW-SSE, with continuous rotation of orientations through E-W trend visible for several sites (e.g. Sites 174, 178, 206, 245, 246; Fig. 13b). Magnetic lineations are characterised by two distinct orientations whatever the foliation strikes (Fig. 13b): (1) E-W to NW-SE trend with a rather gentle plunge for almost all sites, and (2) N-S trend with still gentle plunge for few other (e.g. Sites 217, 228, 238, 247). As shown in map view (Fig. 14a), magnetic foliations exhibit a flip from W-dipping to Edipping, from one side to the other of the massif. Consistently, magnetic lineations $\left(\mathrm{K}_{1}\right)$ switch from W-plunging to E-plunging while the N090-N120 trend remains constant for 59 sites (75\%; Fig. 14b). However, 19 of the sites located in the dome centre display a $\sim \mathrm{N}-\mathrm{S}$ trend (Fig. 14b). Magnetic lineation trends display shallow plunges $\left(\sim 20^{\circ}\right.$; Fig. 14b). In order to qualitatively compare AMS results with available field observations, density contour diagrams have been calculated for individual AMS axes, without the orthogonal constraint in the three axes (Fig. 14b; Jelinek, 1981; Borradaile and Gauthier, 2003).

\subsubsection{Magnetic fabrics of the Yinmawanshan pluton}

From the 403 cores drilled from 50 sites in this pluton, the anisotropy degree $\left(\mathrm{P}_{\mathrm{J}}\right)$ values higher than $20 \%$ are represented by about $50 \%$ of all sites (Table 2). Such a high proportion can be biased by the high shape magnetic anisotropy of magnetite grains which could artificially increase $P_{J}$ values (Tarling and Hrouda, 1993; Dunlop and Özdemir, 1997). Indeed, it seems from our study that $\mathrm{P}_{\mathrm{J}}$ high values correspond to high magnetic susceptibilities, and therefore to high magnetite amount in the rock (e.g. Sites 373, 394, 405, 414; Table 2); such feature is also displayed on Figure 12c which suggests a rough linear relationship between $\mathrm{P}_{\mathrm{J}}$ and $\mathrm{K}_{\mathrm{m}}$. Positive $\mathrm{T}$ values represent $78 \%$ of all samples leading to 
consider the AMS foliation as better defined than the lineation one from a statistical point of view (Table 2 and Figs. 12a and 12b). Yet, magnetic lineation is also statistically welldefined since only 4 sites out of 50 (i.e. Sites 395, 398, 407 and 410) present scattered lineation directions with a mean confidence level ( $\alpha_{95}$ mean) higher than $20^{\circ}$ (Table 2). Figures 12b and 12c argue for a ferromagnetic mineralogy for the granitic rocks of the Yinmawanshan pluton, with high values of $\mathrm{K}_{\mathrm{m}}$ mainly comprised between 2000 and $5000 \mathrm{x}$ $10^{-6} \mathrm{SI}$.

Equal-area projections of $\mathrm{K}_{1}$ and $\mathrm{K}_{3}$ axes are represented in Figure 13 with location of each sampling site. Resulting magnetic planar and linear preferred orientations calculated from site-mean directions are illustrated in Figures 14a and 14b, respectively. Magnetic foliations in the pluton exhibit variable foliation attitudes with rather shallow to moderate dipping for a majority of sites (mean of $40^{\circ}$ ) and steeply to subvertical dipping for several other ones (e.g. Sites 373, 374, 379, 387 and 391; Fig. 13c). Magnetic lineations reveal a consistent E-W trend for some sites (e.g. Sites 371, 403, 409 and 411) while others better display scattered directions (e.g. Sites 373, 375, 387, 391 and 393; Fig. 13c). In map view, magnetic foliations exhibit a concentric pattern which follows the pluton boundary (Fig. 14a). AMS sites showing steeply dipping foliations correspond to the rim granitic facies or to the contact between granitic rocks and surrounding units. In turn, flat lying E-W trending magnetic lineations occur in the eastern part of the pluton while steeply plunging, scattered oriented ones are instead located in the western part, away from the Gudaoling detachment fault (Fig. 14a).

\section{Finite strain mapping}


Within the Gudaoling dome, where igneous rocks are adjacent or nearby migmatitic ones, the measured magnetic fabrics is consistent with macroscopic structural measurements (compare Figs. 2 and 14). Indeed, magnetic foliations are locally parallel to sub-parallel to the foliation measured in the field. Besides, an overall E-W to NW-SE trending magnetic lineations, displaying relatively shallow plunges, is also consistent with the stretching lineation orientations as measured in the field.

Based on both structural measurements and results from the AMS study, spatial variations of the ductile finite strain are discussed here for both massifs. First, foliation trajectory maps are drawn based on individual directional data from both structural measurements and/or AMS data (Fig. 15a). Secondly, finite strain magnitude maps are computed from a qualitative determination of the deformation observed in migmatitic and/or igneous rocks (see Charles et al., 2011a for details; Fig. 15b). The scale used to assess strain intensity is qualitative from isotropic rocks (ranked \#5) to ultramylonitic rocks (ranked \#1). Igneous rocks displaying no apparent macroscopic fabric are scored to 5 for isotropic textures and 4.5 when a preferred orientation has been identified through AMS study. For computation, kriging interpolation is used to predict strain intensity at unsampled/observed locations. It results in a continuous contours map for the entire zone extent. Table 3 and Fig. 15b present semi-variogram model and the contours map of kriging interpolation of strain intensity, respectively.

\subsection{Finite strain within the Gudaoling MCC}

In the Gudaoling MCC, the foliation trajectories display a mean $\sim \mathrm{N}$ striking for the main part of the dome (Fig. 15a). To the SW, north of Anbo city, foliation strikes N150 on average. Trajectories bend in both $\mathrm{N}$ and $\mathrm{S}$ tips of the MCC and as a whole, they draw a 
concentric pattern corresponding to a typical dome structure with foliation planes dipping west in the western flank and east in the eastern one (Fig. 15a; see details in structural analysis, above). Yet trajectories look converging along the GDF, to the east, and partly truncated by the trace of these structure at the same time. The Gudaoling MCC thus displays an asymmetrical geometry with the deepest structural levels of the dome cropping out closer to the GDF roofing the massif (Fig. 15a).

Concerning strain intensity interpolation, variogram analysis reveals an asymmetrical trend with longer correlation distances between data point oriented N155E. Such direction correlates well with the mean foliation planes striking within the dome (Fig. 15a). In the variogram, a non-null value for the nugget effect $\left(C_{0}=0.8272\right)$ intends for deviations of the strain intensity value at local scale, which can be attributed to lithological contrasts as evidenced within the Gudaoling MCC (i.e. alternating granites s.l. and migmatites for the main part). In map view, a low-strained area appears in the north-central part of the dome (Fig. 15b). It strikes north and corresponds to monzogranite accumulation in that area. The southwestern edge of the dome, with $\sim \mathrm{N} 150$ striking mean foliation plane, also displays relatively low strained rocks (Figs. 15a and 15b). As a whole, from core to the eastern rim, strain intensity progressively increases (i.e. "1" to "2") (Fig. 15b). Highly deformed rocks correspond here to the mylonites and ultramylonites of the Gudaoling detachment fault (GDF), as observed in the field.

In more details, interpolated trajectory map also underlines the occurrence of three subdomes aligned along the core of the dome (Fig. 15a). In the southernmost one, foliation planes envelope follows the cartographic trace of the large diorite band lying in the SE part of the dome (compare Figs. 2 and 15a). The core of this subdome corresponds to one of the deepest structural levels of the MCC and a particularly continuous migmatite "body" has been mapped there (Figs. 2 and 15a). Finite strain is of medium- to high-strength through this part 
of the dome core as shown on the interpolated contour map (Fig. 15b). Identification of subdomes has already been done within the Naxos MCC (Aegean area; Gautier et al., 1993; Rey et al., 2011) and the Montagne Noire gneiss dome (French Massif Central; e.g. Gèze, 1949; Van den Driessche and Brun, 1992; Matte et al., 1998; Soula et al., 2001; Charles et al., 2009; Kruckenberg et al., 2011; Rey et al., 2011). Recent thermo-mechanical modelling undertaken by Rey et al. (2011) shows that dome materials can follow a complex depthdependent strain history. Indeed, deep crustal flow and extension have not necessarily the same direction in 3-D and models highlight that steepest foliation corridors, separating subdomes, could develop during MCC exhumation (Rey et al., 2011). Besides, our AMS study reveals two sets of magnetic lineations into the Gudaoling MCC, with shallow to steep plunges: (1) one trending E-W to NW-SE, parallel to the stretching lineations and, (2) one striking $\sim \mathrm{N}-\mathrm{S}$ and approximately located within subdomes, parallel to the dome's core orientation (Fig. 15a). Variability in both trend and plunge of magnetic lineations could thus be explained by changing 3-D materials flow dynamics which principally depend, following Rey et al. (2011), on the depth of rheological transitions (i.e. solidus and brittle/ductile transitions) within given tectonic boundary conditions (e.g. geothermal gradient, mean strain rate).

\subsection{Finite strain within the Yinmawanshan pluton}

To the south of the Gudaoling MCC, the Yinmawanshan pluton is only composed of granitic rocks and strain is inferred from the AMS data. Interpolated trajectory map emphasizes a concentric attitude of magnetic foliations. In addition, trajectories show a circular shape globally parallel to the pluton borders (Fig. 15a). As shown before, magnetic foliation becomes steeper toward the borders of the pluton. On the other hand, the interpolated 
strain intensity map exhibits unstrained rocks in the main part of the pluton, from its centre and up to its western edge (Fig. 15b). There, magnetic lineations display variable trends which can correspond to magmatic flow as evidenced by the predominance of magmatic to weak solid-state microstructures in this area (Fig. 9). In contrast, the eastern border of the pluton is characterised by highest values of the interpolated strain intensity (Fig. 15b). They correspond to the mylonites of the southern extension of the Gudaoling detachment fault and characterised by intense ductile shearing. Increase of simple shear intensity appears gradual from the core of the pluton toward the NE (Fig. 15b). In this particular part of the pluton, magnetic lineations exhibit a constant E-W trend with relatively shallow plunge, parallel to the orientation of stretching lineations measured in the field (Figs. 2 and 14b). Structural study shows that mylonitic rocks of this synkinematic intrusion border exhibit a top-to-the $\mathrm{E}$ sense of shear which is compatible with the kinematics observed in the GDF, along the eastern border of the Gudaoling MCC, further north.

It is noteworthy that the Yinmawanshan pluton is surrounded by isotropic Early Cretaceous granitoids belonging to the upper unit of the Gudaoling MCC (Fig. 2), and in particular the Zhuanghe pluton which seem, to connect to the Yinmawanshan pluton itself (see Figs. 1 and 2).

\section{Age constraints on partial melting within the Gudaoling MCC}

Traditionally considered as a single complex intrusion, the emplacement of the Gudaoling MCC was dated at Early Cretaceous ages (i.e. 127-118 Ma; Guo et al., 2004; Wu et al., 2005a, b) coeval with the emplacement of the Yinmawanshan and Zhuanghe plutons, at 129-120 Ma (Guo et al., 2004; Wu et al., 2005a, b). Conversely, migmatites which have been recognised in this work have not been studied in the massif interiors and the only published 
age, up to now, has been obtained from a sample located along the dome margin which gives a Late Jurassic age (157 \pm 3 Ma; Wu et al., 2005b). Moreover, since Precambrian migmatites exist in the MCC's upper unit, a Precambrian age has thus been attributed to these rocks throughout the region, including the ones within the Gudaoling MCC (LBGMR, 1972, 1974). In this study, leucosome of migmatites has been sampled to better constrain the crustal melting timing in the Gudaoling MCC. U/Pb analyses on zircon have been used (see Appendix C for details).

Sampled migmatites are located in the centre of the MCC (sample 09-114 localised in Figures 2 and 16a; GPS: N39.995 $-\mathrm{E} 122.454^{\circ}$ ). Sample 09-114 is a leucosome of migmatites essentially composed of quartz and feldspar with a few amount of biotite (Fig. 16a). A faint foliation defined by biotite can be observed. It is precisely comprised within the core of the southernmost subdome of the MCC, in the migmatite body rimmed by the quartz diorite cartographic band (Fig. 2). This part of the dome is one of the deepest structural levels (Fig. 4b). As shown on Figure 16a, the sampled leucosome makes part of melt network cutting across a flat lying lens of amphibolite. This structure exemplifies well one of the boudins of the more competent amphibolite layers stretched within the migmatite, in an $\sim$ ESE direction. From this, one can argue for a coeval $\sim \mathrm{E}-\mathrm{W}$ oriented extensional deformation regime with partial melting.

The analysed zircons constitute a homogeneous population of grains $>100 \mu \mathrm{m}$ in length (Fig. 16b). According to the typology proposed by Pupin (1980), the rather prismatic habit of zircons is characteristic of high temperatures (between $750-900^{\circ} \mathrm{C}$ ). Eight analyses yielded consistent ages after ${ }^{207} \mathrm{~Pb} /{ }^{206} \mathrm{~Pb}$ and ${ }^{206} \mathrm{~Pb} /{ }^{238} \mathrm{U}$ ratios and common $\mathrm{Pb}$ corrections with GLITTER and method according to Andersen (2002), respectively (Table 4). These spot analyses yield a mean ${ }^{206} \mathrm{U} /{ }^{238} \mathrm{~Pb}$ age of $153.9 \pm 4.1 \mathrm{Ma}($ Fig. 16b) that are interpreted as the crystallisation age of migmatite leucosome. This age is consistent with the $\mathrm{U} / \mathrm{Pb}$ on zircon age 
calculated by Wu et al. (2005b) at $157 \pm 3$ Ma for migmatites located along the dome eastern border. As migmatites display homogeneous lithological facies throughout the dome, it results that the overall migmatites in the Gudaoling MCC (i.e. from its core to borders) and related partial melting should be attributed to Late Jurassic. A general crustal partial melting may thus have occurred during Late Jurassic (154-157 Ma) in the South Liaodong area. Again, structure of the migmatite argues for contemporaneous melting and $\sim \mathrm{E}-\mathrm{W}$ stretching (Fig. 16a).

\section{Tectonic evolution}

Combining structural analysis with AMS study, our finite strain mapping and new geochronology call for a new interpretation of the tectonic evolution of the South Liaodong peninsula.

While the Gudaoling massif was considered, as a pluton, this study shows that is in fact a metamorphic core complex. Its internal structure is characterised by a $\sim \mathrm{N}$-trending asymmetrical dome of foliation with mineral and stretching lineations consistently oriented N090-120. Lithologies in the dome include migmatites, anatectic granitoids and quartz diorites. Internal finite strain mapping highlights subdomes developed in the deepest structural levels of the lower unit and a systematic increase of ductile deformation toward the east. Indeed, the exhumation of the dome drives to the formation of a major E-dipping detachment fault (GDF). Its E-W to NW-SE extensional shearing is fully compatible with the overall NW-SE kinematics recognised throughout East Asia, during Late Mesozoic continental extension (e.g. Ren et al., 2002; Liu et al., 2005; Lin and Wang, 2006; Daoudene et al., 2009, 2011; Charles et al., 2011a). 
Based on both structural and AMS data, finite strain analysis within the Yinmawanshan pluton strongly argues for a synkinematic emplacement. As shown before, the two branches of the ductile extensional shear zone in that area correspond to the southern prolongation of the Gudaoling detachment fault (GDF). In details, the GDF rapidly dies out, to the south, when entering the Yinmawanshan pluton and the movement looks relaying along the north-eastern border of the massif. In turn, this second ductile shear zone also dies out to the south as no ductile deformation has been observed within the Zhuanghe pluton, considered as the prolongation of the Yinmawanshan to the south and east (see discussion before in Section 4.1). As the GDF progressively dies out, along-strike, within the Yinmawanshan-Zhuanghe plutons, and as the same igneous rocks can be observed on both sides of this main structure, the net movement along this normal ductile shear zone must be limited after the igneous rocks crystallised, at ca. 120-129 Ma (see Figs. 1 and 2 and references therein). Moreover, field structural analysis shows that the Yinmawanshan granite cuts across and/or comprises xenoliths of migmatites from the Gudaoling MCC to the north, migmatites from the South Liaodong MCC to the south and Neoproterozoic (Sinian) sediments to the west (Figs. 1, 2 and 7). This clearly evidences (1) that the Yinmawanshan pluton emplaced within upper crustal levels and, then, (2) that rocks of the lower unit of the Gudaoling MCC were largely exhumed at that time.

A detailed compilation of time-constraints is given in Figure 17a. Ages have been compiled from new geochronological constraints of this study and published data (Wu et al., 2005a, b; Yang et al., 2007b; Lin et al., 2008; Yang et al., 2008) and were interpreted with respects to thermochronometers defined by Dodson (1973). Tectonic history of the South Liaodong area can be drawn as follows.

E-W to ESE-WNW continental extension begins during Late Jurassic times (157-154 Ma) as shown by the coeval stretching of migmatites within the core of the Gudaoling MCC. 
These rocks were parts of the deepest structural levels exhumed within the MCC and coeval to partial melting. At that time, extension affected the entire crust, including the lower crust (Fig. 17b). As shown by modelled cooling paths (Fig. 17a), rocks of the MCC lower unit remained under high temperature conditions up to Early Cretaceous times (127-118 Ma). Anatectic granitoids intruded into the Gudaoling MCC formed a complex alternance of migmatites and granitic rocks (Fig. 17b). Structural measurements in the deformed migmatites are consistent with the AMS results in isotropic igneous rocks. In particular, both lineation types are parallel and constantly display N090-N120E striking which highlights a common deformation regime and strain directions during Late Jurassic and Early Cretaceous.

To the south of the Gudaoling MCC, the synkinematic Yinmawanshan pluton emplaced at 129-120 Ma (Guo et al., 2004) at rather high crustal levels. Emplacement ages are concordant for igneous rocks of the Gudaoling MCC (127-118 Ma) and plutons of the upper unit (e.g. Yinmawanshan 129-120 Ma, Zhuanghe 128-120 Ma). In the Yinmawanshan, deformation is restricted to its northeast border and controlled by the southern termination of the GDF. As discussed above, movement must be limited after the Yinmawanshan-Zhuanghe complex crystallised (i.e. after $\sim 120 \mathrm{Ma}$ ); this period thus marks out the final stages in the tectonic evolution of the GDF and of the Gudaoling MCC exhumation. The Early Cretaceous period also must probably correspond to the development of the Wanfu extensional basin, on top of the GDF.

Finally, Ar/Ar studies of mylonites from the ductile detachment zone, to the east, give the youngest ages at 114-113 Ma (Fig. 17a; Yang et al., 2008) which must correspond to the very last stage of ductile deformation along the GDF (Fig. 17b). Thus, exhumation of the metamorphic units of the Gudaoling MCC, from lower to upper crust, took place in between 127 and 113 Ma (Fig. 17b). The compiled cooling path displays a two stage evolution with a slow exhumation period, from 157 to $\sim 127 \mathrm{Ma}$ and a quite rapid one from $\sim 127$ to $113 \mathrm{Ma}$ 
(Fig. 17a). As shown on Figures 17a and 17c, the cooling path obtained from the Gudaoling MCC is comparable to the one from the South Liaoning MCC with (1) occurrence of Jurassic plutonism, (2) Early Cretaceous igneous rocks crystallisation and (3) exhumation phase of the South Liaodong MCC in between 125-120 Ma and $110 \mathrm{Ma}$ as marked by Ar/Ar ages obtained on synkinematic minerals (Yang et al., 2007b; Lin et al., 2008).

\section{Discussion}

9.1. Modes of crustal deformation during East Asia continental extension

The Liaodong Peninsula (NE China) displays numerous extensional structures related to the Late Mesozoic continental extension that affected East Asia (e.g. South Liaodong MCC: Liu et al., 2005; Lin and Wang, 2006; synkinematic Laohushan pluton ("LA" on Fig. 1): Lin et al., 2007; Cretaceous extensional continental basins: see Wafangdian or Laohushan, Fig. 1). The present study highlights the existence of additional first-order extensional structures through the Liaodong area: the Gudaoling MCC accompanied at the end of its evolution by the synkinematic Yinmawanshan pluton. As discussed by Charles et al. (2011a) MCCs development and synkinematic pluton emplacement do not account for the same amounts of extensional strain. Both geological features have been detailed in this study in a way to better constrain the finite strain within the South Liaodong area. Structural analysis combined with new geochronological constraints show that the development of the Gudaoling MCC followed a two folds evolution. First, an early $\sim \mathrm{E}-\mathrm{W}$ stretching occurred contemporaneously with partial melting of lower crustal levels during Late Jurassic. Overall exhumation of lower crustal units then occurred during Early Cretaceous intrusion of synkinematic granitic rocks. Exhumation is controlled by $\sim \mathrm{E}-\mathrm{W}$ extension, as classically known for the rest of East China at that time, and the development of a major east dipping 
ductile detachment shear zone (GDF). Kinematics, exhumation and anatectic granitoids were almost synchronous in both Gudaoling and South Liaodong MCCs, as shown by compiled cooling paths (compare Figs. 17a and 17b). Besides, structural map displays a southern cartographic termination of the Gudaoling MCC at the approximate latitude of Anbo city (North of the Yinmawanshan pluton; Fig. 18), with finite movements along the GDF dying out to the south. Kinematics within the Gudaoling and the Liaodong MCCs display opposite detachment verging (i.e. top-to-the-east along the GDF, and top-to-the W along the South Liaodong detachment; Liu et al., 2005; Lin and Wang, 2006). According to Tirel et al. (2008), such versatility in the dynamic of the detachments can be explained by very high temperature conditions during extension. Thus, if considering the entire south Liaodong area (see Fig. 18), the Gudaoling and South Liaodong MCCs developed and exhumed in line, during the same period (Late Jurassic to Early Cretaceous) and can be regarded as a single $\mathrm{N}$ to NNE trending $\sim 140 \mathrm{~km}$ extensional band. In a lithospheric extensional setting, MCC development results from a strong tectonic denudation of the mid to lower crust with penetrative ductile flow underneath a heterogeneously stretched upper crust. Detection of such crust-scale structures argues for quite large amount of finite strain. According to analogue and numerical modelling (e.g. Brun, 1999; Tirel et al., 2006, 2008; Rey et al., 2009a, b), the amount of extension roughly corresponds to the width of the outcropping lower unit in the MCC (see also Charles et al., 2011a). The $\sim \mathrm{N}$ striking cartographic band comprising the Gudaoling and South Liaodong MCCs thus accounts for about $30 \mathrm{~km}$ of localised $\sim \mathrm{E}-\mathrm{W}$ to NW-SE horizontal stretching of the crust (Fig. 18).

This study points out that granitic rocks intruded during the late stages of the tectonic evolution of the South Liaodong province, during Gudaoling MCC exhumation (128$118 \mathrm{Ma})$. Some of these intrusions belong to the $\sim \mathrm{N}$-striking extensional band as the anatectic granitoids, included into the MCC and intercalated with migmatites, or the synkinematic 
Yinmawanshan pluton located just between the two MCCs (Fig. 18). Combined structural and AMS analyses show anatectic granitoids recorded significant strain and similar kinematics to those of metamorphic rocks of the dome. On the one hand, strain is of lower magnitude as deformation only localised along the GDF at that time and developed during the late stages of the MCC exhumation (Fig. 17c). On the other hand, our finite strain study also highlights the occurrence of unstrained Early Cretaceous granitic intrusions in the area. Plutons stay outside of the extensional band as described above (i.e. emplaced into the upper unit of the MCC; Fig. 18). These include, in particular, the Zhuanghe pluton which forms the east-southeastern prolongation of the synkinematic Yinmawanshan intrusion but which displays only intrusive contacts with surrounding units and no internal macroscopic strain (Figs. 1 and 18).

Thus, crust of the South Liaodong area displays a strain partitioning during Late Mesozoic continental extension. Indeed, high-strain zones localise where MCC developed, (i.e. below detachments), whereas juxtaposed segments are isotropic or weakly deformed above detachments (Figs. 17c and 18). Finally, while extensional tectonics are sometimes related to the only Early Cretaceous period, this study clearly shows that $\sim \mathrm{E}-\mathrm{W}$ extension lasted from Late Jurassic (157-154 Ma) to Early Cretaceous ( 113 Ma) through South Liaodong area.

\subsection{A field illustration of MCC dynamics and development sequence}

Whatever the scale considered, deformation rate is a first-order parameter controlling rocks rheology. Recent studies, mostly based on thermo-mechanical numerical modelling, discuss the influence of strain rate on the finite structure of Metamorphic Core Complexes (Rey et al., 2009a, b). Two categories have thus been distinguished: fast and slow MCC depending on the strain rate. Fast MCCs typically develop in a few millions years (i.e. ca. 10 
My). They are characterised by localised deformation in the upper crust, isothermal decompression and melts crystallisation at low depth (Rey et al., 2009a, b). However, if the geotherm is high enough then deformation is largely distributed in the middle and lower crust. The resulting dome displays a poørly deformed metamorphic core where deformation is mainly at temperature above the solidus. Slow MCCs develop in a few tens of millions years. This MCC-type would display a metamorphic/migmatitic core with high finite strain (including solid-state deformation) and which crystallised at rather high depth in the crust (> $600 \mathrm{MPa}$; Rey et al., 2009a, b). In a compilation for the duration of MCC development, throughout different continental extensional domains in the world (Charles et al., submitted), typical durations range from less than 10-12 My long for the "fast" MCCs, such as Shuswap, Naxos and the North Menderes (Vanderhaeghe et al., 1997, 1999; Keay et al., 2001; Lorencak et al., 2001; Norlander et al., 2002; Ring et al., 2003; Isik et al., 2004; Ring and Collins, 2005; Brichau et al., 2006; Duchêne et al., 2006) to more than 60 My for the "slow" MCCs, such as South Rhodope, Ruby Mountains and the Snake Range (Miller et al., 1988; Wawrzenitz and Krohe 1998; McGrew et al., 2000; Sullivan and Snoke, 2007).

In the South Liaodong area, the tectonic evolution of the emplacement of the Gudaoling MCC clearly shows a two folds history, as recorded through the shape of the inferred cooling paths (Figs. 17a and 17b). The first stage lasted over the ca. 155 Ma to 130$120 \mathrm{Ma}$. As shown in this study, lower crustal rocks display partial melting coeval with penetrative E-W to NW-SE horizontal stretching (see migmatites in the dome core; Fig. 17c). Late Jurassic migmatites show much more solid-state deformation microstructures than the later Early Cretaceous intrusions. Besides, no trace of localised shearing has been evidenced for that period in the upper crust (Fig. 17c). Such features during the inception phases in the development of the Gudaoling MCC correspond to the crustal necking phase as proposed by Tirel et al. (2008). By contrast, the second stage of the tectonic evolution of the Gudaoling 
area is characterised by (1) a fast cooling of the MCC lower unit and (2) the intrusion of granitic magmas into the upper crust (e.g. Yinmawanshan and Zhuanghe plutons). Deformation is localised and concentrated along the Gudaoling detachment fault, to the eastern border of the MCC. Moreover, Early Cretaceous synkinematic intrusions display strong spatial strain gradients as igneous rocks display no or very limited solid-state deformations within the core of the MCC. Besides, these must have emplaced and crystallised at quite high-levels in the crust as shown in this study. The second stage of the tectonic evolution of the Gudaoling MCC is then much corresponding to the development of a fast MCC-type, according to Rey et al. (2009a, b). It can also be regarded as the late stage of dome amplification and exhumation, as defined by Tirel et al. (2008), when movement localised along the detachment fault, into upper crust, and coeval extensional basin developed on top of the system (Fig. 17c). Thus, considering the two main stages for the Gudaoling MCC (crustal necking and dome amplification-exhumation), it could correspond to a slow, then fast MCC.

The study highlights that, combining structural analysis with AMS study and U/Pb constraints, one can constrain finite strain and kinematics within and around metamorphic core complexes. While our understanding of MCCs development highly benefited from numerical and analogue modelling during last years (see Brun, 1999; Tirel et al., 2006, 2008; Rey et al., 2009a, b), this study also shows that the South Liaodong area (East China) can be regarded as a good field illustration of mechanical processes and sequence leading to MCCs dynamics and structural development.

\subsection{Role of crustal partial melting}


Former studies on metamorphic core complexes point out that, when observed, partial melting may take place during decompression and, hence, exhumation of lower crust materials in the core of MCC (e.g. Teyssier and Whitney, 2002). In contrast, this study shows that partial melting of the lower crust levels took place very early during the development of the Gudaoling MCC, at ca. 157-154 Ma, before the fast exhumation of the migmatites/anatectic granitoids in the dome (see Fig. 17c and discussion above). Thus, in this case study, partial melting of lower crust better appears as a precondition for initiation and further development of the MCC. Such feature is in total accordance with previous thermomechanical numerical models which highlight that a pre-existing soft rheological anomaly, within lower crust, highly favours the initiation of localised extension throughout the crust (Tirel et al., 2008). Igneous massifs emplacement is well documented for Late Mesozoic times across East Asia (Li, 2000; Wang et al., 1998; Wu et al., 2000, 2005a, 2005b, 2007). The South Liaodong area displays numerous granitic rocks intruded during the Gudaoling MCC exhumation (128-113 Ma; Fig. 17c) and this strong magmatic activity period coincides with the late fast development stages of the Gudaoling MCC. MCCs develop within wide rift systems (Brun, 1999). Wide rift systems are marked by extensional structures which develop over large distances throughout continental crust (i.e. several hundred of kilometres; Buck, 1991; Corti et al., 2003). In that sense, numerous tectonic indicators suggest that East Asia was a wide rift system during Late Mesozoic times (e.g. Ren et al., 2002; Zhai et al., 2007; Charles et al., submitted). In details, deformation is localised along major faults in the upper crust while the rest of the lithosphere typically displays pervasive ductile deformations over long distances. Such tectonic environment locally yields to the development of MCCs. From this, development of wide rifts may be favoured by partial melting at both local and regional scales. First, previous modelling studies strongly suggest that local "soft" anomalies in the lower crust help to the initiation of MCC development, as discussed before (Tirel et al., 
2008). Second, at regional-scale, widespread melting and/or magmatism can significantly reduce the bulk lithosphere strength, emphasizing continuous pervasive deformation of the deepest levels of the lithosphere (Van der Molen and Paterson, 1979; Reynolds and Rehrig, 1980; Coney and Harms, 1984; Lynch and Morgan, 1987; see synthesis in Handy and Brun, 2004). Then, within South Liaodong area, the continental crust mechanical behaviour in the Late Jurassic and Early Cretaceous may have been strongly controlled by melts generation at the onset and during the extension period. We interpret here the magmatic activity $s . l$ as the first-order parameter controlling the mode of extension throughout East China, both at local and regional-scale.

As far as migmatisation happened before the MCC exhumation period itself, another external cause must be advanced for driving partial melting of the lower crust rocks. Seismic tomography and magma xenoliths studies show that, in East China, the continental lithosphere was thinned over $>100 \mathrm{~km}$ between Ordovician and Cenozoic (Menzies et al., 1993; Griffin et al., 1998; Chen et al., 2008; Chen, 2010;) with a main thinning period during JurassicCretaceous (Gao et al., 2002; Fu et al., 2005; Chen, 2010). Lithospheric thickness has been estimated to $\sim 60 \mathrm{~km}$ in the study area for Jurassic-Cretaceous (Chen et al., 2008, Chen, 2010); this induces a high thermal gradient at that time. Such feature has also been shown by palaeogradients reconstructions through continental basin analyses (Fu et al., 2005). Consequently, early partial melting of the lower crust, as observed in the South Liaodong, must probably result from increasing thermal conditions in the area. Migmatites thus constituted a local soft anomaly to initiate the development of $\mathrm{MCC}$ at that location. Besides, increasing heat advection from asthenosphere allows generating lower crust ductile flow and preserving a flat-lying Moho during MCC exhumation within the crust (Block and Royden, 1990; Buck, 1991; Ranalli, 1997). 
From a dynamical point of view, deformation in wide rift systems is traditionally considered as driven by internal forces (e.g. post-orogenic collapse; Buck, 1991; Corti et al., 2003). However, recent studies also highlight the need of specific boundary conditions (e.g. slab retreat, change in subduction velocity) to promote the development of wide rift systems within the continental crust (Lister and Davis, 1989; Rosenbaum et al., 2008; Jolivet et al., 2009; Jolivet and Brun, 2010; Rey and Müller, 2010). We propose here that both thermal and kinematical boundary conditions necessary to develop the East Asia wide rift system (and MCC) are consequences from the evolution of the active margin, to the east, with slab retreat during ongoing westward subduction of the palaeo-Pacific plate.

\section{Conclusions}

1. The Gudaoling dome is an asymmetric Metamorphic Core Complex composed of migmatites and anatectic granitoids, bounded by the Gudaoling detachment fault (GDF). MCC was exhumed from Upper Jurassic (ca. 157-154 Ma) to Early Cretaceous (ca. 128-113 Ma) and associated with a strong E-W to NW-SE horizontal crustal stretching;

2. The Yinmawanshan massif is a synkinematic pluton emplaced during Early Cretaceous during last stages of the Gudaoling detachment fault into an E-W to NWSE extensional setting;

3. The Gudaoling MCC and Yinmawanshan pluton belong to a $\sim 140 \times 30 \mathrm{~km}$ extensional band, comprising also the South Liaodong MCC, and showing high stretching amounts; 
4. From the new and existing radiochronological data, the Gudaoling MCC exhibits a protracted process development with two phases (a slow upper crustal necking and then, a fast MCC amplification; Tirel et al., 2008; Rey et al., 2009a, b);

5. This integrated study (field structural work, AMS and geochronological studies) brings field evidences of the two main steps for MCC dynamics and structural development (i.e. crustal necking and dome amplification/exhumation), corroborating published thermo-mechanical numerical modelling (Tirel et al., 2008);

6. Owing to increase of thermal conditions during Jurassic-Cretaceous in the Liaodong Peninsula, partial melting involved local soft anomaly initiating the development of MCCs.

\section{Acknowledgments}

This study benefited from a grant in the frame of the French national "Failles-FluidesFlux" project supported by the INSU-CNRS. The field work was financed by the Chinese National 973 Project $n^{\circ}$ 2009CB825008. The first author also benefited a scholarship grant from the French Minister of Education and Research. Pr. F.Y. Wu (IGGCAS) is thanked for $\mathrm{U} / \mathrm{Pb}$ datation in his geochronology laboratory. Dr. F. Choulet (ISTO) is thanked for his help for $\mathrm{U} / \mathrm{Pb}$ datation measurements at Beijing. We present our special thanks to Dr. K. Chen (IGGCAS-Université d'Orléans), Mr. J. Wang (IGGCAS) and Dr. Y. Chu (IGGCAS) for their supports on the field during AMS sampling. Mrs. P. Benoist (ISTO) is also acknowledged for mineral separation. We greatly thanked Dr. C. Tirel, Pr. P. Rey and Dr. F. Storti (Editor) for their constructive remarks to improve this paper.

\section{Appendix A. Petrofabrics and microstructures criteria}


- Magmatic microstructure

Magmatic microstructure is characterized by well-developed euhedral crystals of minerals such as feldspar and micas which are not internally deformed (Figs. 8a and $8 \mathbf{b}$ ). Quartz grains present very weak undulose extinction indicating the absence of plastic deformation. Plagioclase crystals exhibit igneous zonation, and most of them have euhedral crystal habits. Biotite platelets are euhedral with a sharp extinction, neither kinked nor bent, and often isolated in a quartz-feldspar groundmass (Fig. 8a and 8b). K-feldspars do not display plastic deformation. They appear unbroken and not surrounded by recrystallized aggregates. Amphibole crystals exhibit euhedral habits with well-defined rhombic-shape basal section, and are not internally deformed. Parallel to sub-parallel alignment of elongate euhedral crystals is observed implying sufficient low viscosity for crystals to rotate without undergoing plastic deformation. All evidences described above imply that the rock did not experience significant high temperature subsolidus strain and recrystallization in that case.

\section{- Weak solid-state fabric}

Appearance of solid-state deformation in granitic rocks mainly depends on melt percentage and ability of minerals and their shapes to accommodate strain (Paterson et al., 1998). Thus, weak solid-state fabric is characterised by minerals which are more deformed than those present in the magmatically deformed rocks. Minerals exhibit high temperature plastic deformation evidences such as quartz grains partially replaced by subgrains with chessboard pattern and undulose extinction (Figs. 8c and 8d). Quartz grains joints are lobate, or even slightly serrated (Figs. 8c and 8d). The beginning of dynamic recrystallisation process is shown by occurrence of new recrystallized and small-sized quartz grains development in some places. Biotite crystals become elongated and slightly kinked with bevel 
extinction. Feldspar grains present undulose extinction and subhedral crystals habits with several myrmekites. This microstructure developed in the transitional rheological state from magmatic to solid-state flow.

- Moderate solid-state fabric

Moderate solid-state fabric is clearly shown by microstructural evidences such as mosaic of quartz small recrystallized grains (Figs. 8e and 8f). This mosaic texture of neograins with serrated boundaries is typical of dynamic recrystallization, even if aggregates and recrystallized grains do not exhibit a mylonitic fabric. K-feldspars show microcline twinning and marginal replacement by myrmekite illustrating rocks deformed in the solidstate (Eggleton and Buseck, 1980; Bell and Johnson, 1989; Simpson and Wintsch, 1989). Combined brittle-ductile deformation is evidenced by the occurrence of fractured feldspars with quartz-filled veins. Elongate biotite crystals are kinked and internally deformed.

- Intense solid-state fabric

The last recognised microstructure corresponds to mylonitic fabric developed in close vicinity to the Gudaoling detachment fault (GDF). Intense solid-state fabric is characterised by strongly recrystallized quartz grains organised in ribbons (Figs. 8g and $8 \mathbf{h}$ ). Quartz and feldspar extremely fine-grained tails occur on residual phenocryst of K-feldspar. Biotite folia anastomose around deformed porphyroclast of K-feldspar or plagioclase. Mica fish is often observed which allows determining kinematic. Solid-state flow and sense of shear are also characterised by $\sigma$ - and $\delta$-type mantled porphyroclast of K-feldspar.

\section{Appendix B. AMS sampling and laboratory measurements procedure}


AMS sampling was carried out with a portable gasoline drill and the cores were oriented with magnetic and solar compasses, when it was possible. The average difference between magnetic and solar declinations is about $-7.5^{\circ}$ and $-7.3^{\circ}$ for the Gudaoling and Yinmawanshan granitic rocks, respectively. As a result, cores have undergone a declination correction. The cores were cut into standard specimens of $22 \mathrm{~mm}$ in length and $25 \mathrm{~mm}$ in diameter for the AMS measurements.

The bulk magnetic susceptibility, AMS and thermomagnetic curves are measured thanks to an CAGICO CS3 coupled KLY-3S Kappabridge apparatus. Measurements of Isothermal Remanent Magnetization (IRM, acquired with ASC Scientific IM-10-30) were performed with an (CAGICO JR5-A spinner magnetometer. Latter measures have been obtained at the Institut des Sciences de la Terre d'Orléans (ISTO). Magnetic hysteresis curves are obtained by a magnetic inductometer at the Laboratoire Paléomagnétique de Saint-Maur (IPG-Paris). The average orientation of the three principal ellipsoidal axes of AMS $\left(K_{1}>K_{2}>K_{3}\right)$ for groups of samples are computed with ANISOFT software using Jelinek's statistics (Jelinek, 1981).

\section{Appendix C. U/Pb analyses on zircon}

The detailed procedure can be found in Xie et al. (2008). Zircon crystals were obtained from crushed rock using a combination of heavy liquid and magnetic separation techniques at

the Institut des Sciences de la Terre d'Orléans (ISTO). Individual crystals were hand-picked and mounted in the epoxy resin. Experiments were carried out at the (Q)-ICP-MS laboratory of the Institute of Geology and Geophysics, Chinese Academy of Sciences, Beijing. An Agilent 7500a quadruple (Q)-ICPMS was used for simultaneous determination of zircon $\mathrm{U} / \mathrm{Pb}$ age and trace elements with an attached GeoLas Plus $193 \mathrm{~nm}$ excimer ArF laser-ablation 
system. Extraction lines were purged for over $1 \mathrm{~h}$ prior to each analytical session to reduce $\mathrm{Pb}$ on the surface to ${ }^{204} \mathrm{~Pb}<50 \mathrm{cps}$ in the gas blank. The measurements were carried out using time resolved analysis operating in a fast, peak hopping sequence in DUAL detector mode. Rawcount rates for ${ }^{29} \mathrm{Si},{ }^{204} \mathrm{~Pb},{ }^{206} \mathrm{~Pb},{ }^{207} \mathrm{~Pb},{ }^{208} \mathrm{~Pb},{ }^{232} \mathrm{Th}$ and ${ }^{238} \mathrm{U}$ were collected for age determination. ${ }^{202} \mathrm{Hg}$ is usually $<10 \mathrm{cps}$ in the gas blank, therefore the contribution of ${ }^{204} \mathrm{Hg}$ to

${ }^{204} \mathrm{~Pb}$ is negligible and is not considered further. The integration time for four $\mathrm{Pb}$ isotopes was $\sim 60 \mathrm{~ms}$, whereas for the other isotopes (including ${ }^{29} \mathrm{Si},{ }^{232} \mathrm{Th}$ and ${ }^{238} \mathrm{U}$ ), it was $30 \mathrm{~ms}$. Data were acquired over $30 \mathrm{~s}$ with the laser off and $40 \mathrm{~s}$ with the laser on, giving ca. $340(=170$ reading/replicate $\mathrm{x} 2$ sweeps) mass scans for a penetration depth of ca. $20 \mu \mathrm{m}$. $\mathrm{U}$, Th and $\mathrm{Pb}$ concentrations were calibrated by using ${ }^{29} \mathrm{Si}$ as internal standard and NIST SRM 610 as external standard. ${ }^{207} \mathrm{~Pb} /{ }^{206} \mathrm{~Pb}$ and ${ }^{206} \mathrm{~Pb} /{ }^{238} \mathrm{U}$ ratios were calculated using GLITTER 4.0 (Jackson et al., 2004), which was then corrected using the zircon 91500 as external standard. The ${ }^{207} \mathrm{~Pb} /{ }^{235} \mathrm{U}$ ratio was calculated from the values of ${ }^{207} \mathrm{~Pb} /{ }^{206} \mathrm{~Pb}$ and ${ }^{206} \mathrm{~Pb} /{ }^{238} \mathrm{U}$. Common $\mathrm{Pb}$ was corrected according to the method proposed by Andersen (2002). The ${ }^{206} \mathrm{~Pb} /{ }^{238} \mathrm{U}$ weighted ages and concordia plot were processed using ISOPLOT 3.1 (Ludwig, 2004). Errors of individual analyses are based on counting statistics and are given at the $1 \sigma$ level.

\section{References}

Allen, M.B., McDonald, D.I., Zhao, X., Vincent, S., Brouet-Menzies, C., 1997. Early Cenozoic two-phase extension and late Cenozoic thermal subsidence and inversion of the Bohai Basin, Northern China. Marine Petrology Geology 14, 951-972.

Andersen, T., 2002. Correction of common lead in U-Pb analyses that do not report ${ }^{204} \mathrm{~Pb}$. Chemical Geology 192, 59-79. 
Archanjo, C.J., Launeau, P., Bouchez, J.L., 1995. Magnetic fabrics vs magnetite and biotite shape fabrics of the magnetite-bearing granite pluton of Garmeleiras (northeast Brazil). Physics of the Earth and Planetary Interiors 85, 63-75.

Bell, T.H., Johnson, S.E., 1989. Porphyroclast intrusion trails: the key to orogenesis. Journal of Metamorphic Geology 3, 109-118.

Berthé, D., Choukroune, P., Jegouzo, P., 1979. Orthogneiss mylonite and non coaxial deformation of granites: the example of the South Armorican Shear Zone. Journal of Structural Geology 1, 31-42.

Block, L., Royden, L.H., 1990. Core complex geometries and regional scale flow in the lower crust, Tectonics 9, 55-567.

Borradaile, G. J., Henry, B., 1997. Tectonic applications of magnetic susceptibility and its anisotropy. Earth Science Reviews 42, 49-93.

Borradaile, G.J., Gauthier, D., 2003. Emplacement of an Archean gneiss dome, northern Ontario, Canada: inflation inferred from magnetic fabrics. Tectonics 22, 1011. doi: 10.1029/2002TC001443.

Bouchez, J.L., 1997. Granite is never isotropic: an introduction to AMS studies in granitic rocks. In: Bouchez, J.L., Hutton, D.H.W., Stephens, W.E., (Eds), Granite: from segregation of melt to emplacement fabrics, Kluwer Academic Publishers, 95-112. 
Bouchez, J.L., 2000. Anisotropie de susceptibilité magnétique et fabrique des granites. Comptes Rendus de l'Académie des Sciences 330, 1-14.

Brichau, S., Ring, U., Ketcham, R.A., Carter, A., Stockli, D., Brunel, M., 2006. Constraining the long-term evolution of the slip rate for a major extensional fault system in the central Aegean, Greece, using thermochronology. Earth and Planetary Science Letters 241, 293-306.

Brun, J.P., 1999. Narrow rifts versus wide rifts: inferences for the mechanics of rifting from laboratory experiments. Philosophical Transactions of the Royal Society of London, Series A $357,695-712$.

Buck, W.R., 1991. Modes of continental lithospheric extension. Journal of Geophysical Research 96(B12), 161-178. doi:10.1029/91JB01485.

Charles, N., Faure, M., Chen, Y., 2009. The Montagne Noire migmatitic dome emplacement (French Massif Central): new insights from petrofabric and AMS studies. Journal of Structural Geology 31, 1423-1440.

Charles, N., 2010. Mechanisms for the Late Mesozoic continental extension in eastern Asia. Thèse doctorale de l'Université d'Orléans (PhD), 486 p.

Charles, N., Gumiaux, C., Augier, R., Chen, Y., Zhu, R. and Lin, W., 2011a. Metamorphic Core Complex vs. Synkinematic pluton in continental extension setting: Insights from key structures (Shandong Province, eastern China). Journal of Asian Earth Sciences 40, 261-278. 
Charles, N., Chen, Y., Augier, R., Gumiaux, C., Lin, W., Faure, M., Monié, P., Choulet, F., Wu, F.Y., Zhu, R., Wang, Q., 2011b. Palaeomagnetic constraints from granodioritic plutons (Jiaodong Peninsula): New insights on Late Mesozoic continental extension in eastern Asia. Physics of the Earth and Planetary Interiors 187, 276-291.

Charles, N., Augier, R., Gumiaux, C., Monié, P., Chen, Y., Faure, M., Zhu, R., submitted to Gondwana Research. Timing, duration and role of magmatism in wide rift systems: Insights from the Jiaodong Peninsula (China, East Asia).

Chen, L., Tao, W., Zhao, L., Zheng, T., 2008. Distinct lateral variation of lithospheric thickness in the Northeastern North China Craton. Earth and Planetary Science Letters 267, $56-68$.

Chen, L., 2010. Concordant structural variations from the surface to the base of the upper mantle in the North China Craton and its tectonic implications. Lithos, doi:10.1016/j.lithos.2009.12.007.

Coney, P.J., Harms, T.A., 1984. Cordilleran metamorphic core complexes: Cenozoic extensional relics of Mesozoic compression. Geology 12, 550-554.

Corti, G., Bonini, M., Conticelli, S., Innocenti, F., Manetti, P., Sokoutis, D., 2003. Analogue modelling of continental extension: a review focused on the relations between patterns of deformation and the presence of magma. Earth Science Reviews 63, 169-247. 
Crittenden, M.D., Coney, P.J., Davis, G.H., 1980. Tectonic significance of metamorphic core complexes of the North American Cordillera. Memories of Geological Society of America, 153.

Daoudene, Y., Gapais, D., Ledru, P., Cocherie, A., Hocquet, S. and Donskaya, T.V., 2009. The Ereendavaa Range (north-eastern Mongolia): an additional argument for Mesozoic extension throughout eastern Asia. International Journal of Earth Sciences (Geol Rundsch), doi: 10.1007/s00531-008-0412-2 (in press).

Daoudene, Y., Ruffet, G., Cocherie, A., Ledru, P., Gapais, D., 2011. Timing of exhumation of the Ereendavaa metamorphic core complex (north-eastern Mongolia) - U-Pb and ${ }^{40} \mathrm{Ar} /{ }^{39} \mathrm{Ar}$ constraints. Journal of Asian Earth Sciences (in press), doi:10.1016/j.jseaes.2011.04.009.

Darby, B.J., Davis, G.A., Zhang, X., Wu, F., Wilde, S., Yang, J., 2004. The newly discovered Waziyu metamorphic core complex, Yiwulüshan, western Liaoning province, Northwest China. Earth Science Frontiers 11, 145-155.

Davis, G.H., Coney, P.J., 1979. Geologic development of the Cordilleran metamorphic core complexes. Geology 7, 120-124.

Davis, G.A., Qian, X., Zheng, Y., Yu, H., Wang, C., Mao, T.H., Gehrels, G.E., Muhammad S., Fryxell, J.E., 1996. Mesozoic deformation and plutonism in the Yunmeng Shan: A Chinese metamorphic core complex north of Beijing, China. In: A. Yin \& T.A. Harrison, Eds., The tectonic evolution of Asia. Cambridge University Press, New York, 253-280. 
Denèle, Y., Lecomte, E., Jolivet, L., Lacombe, O., Labrousse, L., Huet, B., Le Pourhiet, L., 2011. Granite intrusion in a metamorphic core complex: The example of the Mykonos laccolith (Cyclades, Greece). Tectonophysics 501, 52-70.

Dodson, M., 1973. Closure temperature in cooling geochronological and petrological systems. Contributions to Mineralogy and Petrology 40, 259-274.

Donskaya, T.V., Windley, B.F., Mazukabzov, A.M., Kröner, A., Sklyarov, E.V., Gladkochub, D.P., Ponomarchuk, V.A., Badarch, G., Reichow, M.K., Hegner, E., 2008. Age and evolution of late Mesozoic metamorphic core complexes in southern Siberia and northern Mongolia. Journal of Geological Society of London 165, 405-421.

Duchêne, S., Aïssa, R., Vanderhaeghe, O., 2006. Pressure-Temperature-time Evolution of Metamorphic Rocks from Naxos (Cyclades, Greece): Constraints from Thermobarometry and $\mathrm{Rb} / \mathrm{Sr}$ dating. Geodinamica Acta 19, 299-319.

Dunlop, D.J., Özdemir, Ö., 1997. Rock Magnetism, Fundamentals and Frontiers. Cambridge University Press, Cambridge, 573 p.

Eggleton, R.A., Buseck, P.R., 1980. The orthoclase-microcline inversion: a high-resolution transmission electron microprobe study and strain analysis. Contributions to Mineralogy and Petrology 74, 123-133.

Fu, M., Hu, S., Wang, J., 2005. Thermal regime transition in eastern North China and its tectonic implication. Science in China Series D 48, 840-848. 
Gao, S., Rudnick, R.L., Carlson, R.W., McDonough, W.F., Liu, Y.S., 2002. Re-Os evidence for replacement of ancient mantle lithosphere beneath the North China Craton. Earth and Planetary Science Letters 198, 307-322.

Gapais, D., Barbarin, B., 1986. Quartz fabric transition in a cooling syntectonic granite (Hermitage Massif, France). Tectonophysics 125, 357-370.

Gautier, P., Ballèvre, M., Brun, J.P., Jolivet, L., 1990. Extension ductile et bassins sédimentaires mio-pliocènes dans les Cyclades (îles de Naxos et Paros). Comptes-Rendus de l'Académie des Sciences de Paris 310, 147-153.

Gautier, P., Brun, J.P., Jolivet, L., 1993. Structure and kinematics of upper Cenozoic extensional detachment on Naxos and Paros (Cyclades Islands, Greece). Tectonics 12, 11801194.

Gèze, B., 1949. Etude géologique de la Montagne Noire et des Cévennes méridionales. Mémoire de la Société Géologique de France 62, 1-215.

Graham, J. W., 1954. Magnetic susceptibility anisotropy, an unexploited petrofabric element. Geological Society of America Bulletin 65, 1257-1258.

Grégoire, V., Saint Blanquat (de), M., Nédélec, A., Bouchez, J.L., 1995. Shape anisotropy vs. magnetic interactions of magnetite grains: experiments and application to AMS in granitic rocks. Geophysical Research Letters 18, 2193-2196. 
Grégoire, V., Darrozes, J., Gaillot, P., Nédélec, A., 1998. Magnetite grain shape fabric and distribution anisotropy vs rock magnetic fabric: a three-dimensional case study. Journal of Structural Geology 20, 937-944.

Griffin, W.L., Andi, Z., O'Reilly, S.Y., Ryan, C.G., 1998. Phanerozoic evolution of the lithosphere beneath the Sino-Korean craton. In: Flower, M., Ching, S.L., Lo, C.H., Lee, T.Y. (Eds), Mantle dynamics and plate interactions in East Asia. AGU Geodynamics Series 27, 107-126.

Guo, C.L., Wu, F.Y., Yang, J.H., Lin, J.Q., Sun, D.Y., 2004. The extensional setting of the Early Cretaceous magmatism in eastern China: example from the Yinmawanshan pluton in southern Liaodong Peninsula. Acta Petrologica Sinica 20, 1193-1204 (in Chinese with English abstract).

Handy, M.R., Brun, J.P., 2004. Seismicity, structure and strength of the lithosphere. Earth and Planetary Science Letters 223, 427-441.

Hibbard, M., 1987. Deformation of incompletely crystallized magma systems: granitic gneisses and their tectonic implications. Journal of Geology 95, 543-561.

Hrouda, F., 1982. Magnetic anisotropy of rocks and its application in geology and geophysics. Geophys. Surveys 5, 37-82. 
Isik, V., Tekeli, O., Seyitoglu, G., 2004. The ${ }^{40} \mathrm{Ar} /{ }^{39} \mathrm{Ar}$ age of extensional ductile deformation and granitoid intrusion in the northern Menderes core complex: implications for the initiation of extensional tectonics in western Turkey. Journal of Asian Earth Sciences 23, 555-566.

Jackson, S.E., Pearson, N.J., Griffin, W.L., Belousova, E.A., 2004. The application of laser ablation inductively coupled plasma-mass spectrometry (LA-ICP-MS) to in situ U-Pb zircon geochronology. Chemical Geology 211, 47-69.

Jelinek, V., 1981. Characterization of the magnetic fabric of rocks. Tectonophysics 79, 63.

Jolivet, L., Famin, V., Mehl, C., Parra, T., Aubourg, C., Hébert, R., Philippot, P., 2004. Strain localization during crustal-scale boudinage to form extensional metamorphic domes in the Aegean Sea. In: Withney, D.L., Teyssier, C., Siddoway, C.S., 2004. Gneiss domes in orogeny: Boulder, Colorado. Geological Society of America, Special Paper 380, 185-210.

Jolivet, L., Faccenna, C., Piromallo, C., 2009. From mantle to crust: Stretching the Mediterranean. Earth and Planetary Science Letters 285, 198-209.

Jolivet, L., Brun, J.P., 2010. Cenozoic geodynamic evolution of the Aegean. International Journal of Earth Sciences 99, 109-138.

Joly, A., Faure, M., Martelet, G., Chen, Y., 2009. Gravity inversion, AMS and geochronological investigations of syntectonic granitic plutons in the southern part of the Variscan French Massif Central. Journal of Structural Geology 31, 421-443. 
Keay, S., Lister, G., Buick, I., 2001. The timing of partial melting, Barrovian metamorphism and granite intrusion in the Naxos metamorphic core complex, Cyclades, Aegean Sea, Greece. Tectonophysics 342, 275-312.

Kruckenberg, S.C., Vanderhaeghe, O., Ferré, E.C., Teyssier, C., Whitney, D.L., 2011. Flow of partially molten crust and the internal dynamics of a migmatite dome, Naxos, Greece. Tectonics 40, doi:10.1029/2010TC002751.

LBGMR (Liaoning Bureau of Geology and Mineral Resources), 1972. Regional Geology of Liaoning Province. Geological Publishing House, Beijing (in Chinese with English summary).

LBGMR (Liaoning Bureau of Geology and Mineral Resources), 1974. Regional Geology of Liaoning Province. Geological Publishing House, Beijing (in Chinese with English summary).

LBGMR (Liaoning Bureau of Geology and Mineral Resources), 1989. Regional Geology of Liaoning Province. Geological Publishing House, Beijing (in Chinese with English summary).

LBGMR (Liaoning Bureau of Geology and Mineral Resources), 1994. Regional Geology of Liaoning Province. Geological Publishing House, Beijing (in Chinese with English summary). 
Li, X.H., 2000. Cretaceous magmatism and lithospheric extension in southeast China. Journal of Asian Earth Science 18, 293-305.

Lin, W., Chen, Y., Faure, M., Wang, Q., 2003. Tectonic implications of new Late Cretaceous paleomagnetic constraints from Eastern Liaoning Peninsula, NE China. Journal of Geophysical Research 108, doi:10.1029/2002JB002169.

Lin, W., Wang, Q., 2006. Late Mesozoic extensional tectonics in the North China Block: a crustal response to subcontinental mantle removal? Bulletin de la Société Géologique de France 177, 287-294.

Lin, W., Faure, M., Monié, P., Wang, Q.C., 2007. Polyphase Mesozoic tectonics in the eastern part of the North China Blocks: insights from the Liaoning Peninsula massif (NE China). In: Zhai, M.-G., Windley, B.F., Kusky, T.M. \& Meng, Q.R. (eds), 2007. Mesozoic sub-continental lithospheric thinning under eastern Asia. Geological Society, London, Special Publications 280, 153-170.

Lin, W., Faure, M., Monié, P., Schärer, U., Panis, D., 2008. Mesozoic extensional tectonics in Eastern Asia : The South Liaodong Peninsula Metamorphic Core Complex (NE China). Journal of Geology 116, 134-154.

Lister, G.S., Banga, G., Feenstra, A, 1984. Metamorphic core complexes of Cordilleran type in Cyclades, Aegean Sea, Greece. Geology 12, 221-225. 
Lister, G.S., Davis, G.A., 1989. The origin of metamorphic core complexes and detachments faults formed during Tertiary continental extension in the northern Colorado River region, USA. Journal of Structural Geology 11, 65-94.

Liu, H.F., 1986. Geodynamic scenario and structural styles of Mesozoic and Cenozoic basins in China. Am. Assoc. Pet. Geol. Bulletin 70, 377-395.

Liu, D.Y., Nutman, A.P., Compston, W., Wu, J.S., Shen, Q.H., 1992. Remnants of >3800 Ma crust in the Chinese part of the Sino-Korean craton. Geology 20, 339-342.

Liu, J., Davis, G., Lin, Z., Wu, F., 2005. The Liaonan metamorphic core complex, southeastern Liaoning Province, North China: A likely contributor to Cretaceous rotation of eastern Liaoning, Korea and contiguous areas. Tectonophysics 407, 65-80.

Lorencak, M., Seward, D., Vanderhaeghe, O., Teyssier, C., Burg, J. P., 2001. Lowtemperature cooling history of the Shuswap metamorphic core complex, British Columbia: constraints from apatite and zircon fission-track ages. Canadian Journal of Earth Sciences 38, $1615-1625$.

Lu, X.P., Wu, F.Y., Lin, J.Q., Sun, D.Y., Zhang, Y.B., Guo, C.L., 2004. Geochronological successions of the Early Precambrian granitic magmatism in Southern Liaodong Peninsula and its constraints on tectonic evolution of the North China craton. Chinese Journal of Geology 39, 123-138 (in Chinese). 
Ludwig, K.R., 2004. User's manual for ISOPLOT/EX a geochronological toolkit for Microsoft Excel (version 3.1). Berkeley Geochronology Center Special Publication 4, 70.

Lynch, H.D., Morgan, P., 1987. The tensile strength of the lithosphere and the localisation of extension. In: Coward, M.P., Dewey, J.F., Hancock, P.L. (Eds), Continental extensional tectonics. Geological Society Special Publications 28, 53-65.

Matte, P., Lancelot, J., Mattauer, M., 1998. La zone axiale Hercynienne de la Montagne Noire n'est pas un "metamorphic core complex" extensif mais un anticlinal post-nappe à cœur anatectique. Geodinamica Acta 11, 13-22.

McGrew, A.J., Peters, M.T., Wright, J.E., 2000. Thermobarometric constraints on the tectonothermal evolution of the East Humboldt Range metamorphic core complex, Nevada. Geol. Soc. Am. 112, 45-60.

Meng, Q., 2003. What drove late Mesozoic extension of the northern China-Mongolia tract? Tectonophysics 369, 155-174.

Menzies, M.A., Fan, W.M., Zhang, M., 1993. Palaeozoic and Cenozoic lithoprobes and the loss of >120 km of Archean lithosphere, Sino-Korean Craton, China, in: Prichard, H.M., Alabaster, T., Harris, N.B.W., Neary, C.R. (Eds), Magmatic processes and plate tectonics, Geological Society, London, Special Publications 76, 71-81.

Miller, E. L., Gans, P. B., Wright, J. E., 1988. Metamorphic history of the east-central Basin and Range province: Tectonic setting and relationship to magmatism In: Metamorphism and 
crustal evolution of the western United States (Ernst, W. G., ed.). Englewood Cliffs, New Jersey Prentice-Hall Inc., 650-682.

Norlander, B.H., Whitney, D.L., Teyssier, C., Vanderhaeghe, O., 2002. Partial melting and decompression of the Thor-Odin dome, Shuswap metamorphic core complex, Canadian Cordillera. Lithos 61, 103-125.

Passchier, C.W., Trouw, R.A.J., 2005. Microtectonics. Springer-Verlag, Berlin, 2nd edition, $366 p$.

Paterson, S.R., Vernon, R.H., Tobisch, O.T., 1989. A view of criteria for the identification of magmatic and tectonic foliations in granitoids. Journal of Structural Geology 11, 349-363.

Paterson, S.R., Fowler, T.K., Schmidt, K.L., Yoshinobu, A.S., Yuan, E.S., Miller, R.B., 1998. Interpreting magmatic fabric patterns in plutons. Lithos $44,53-82$.

Pupin, J.P., 1980. Zircon and granite petrology. Contributions to Mineralogy and Petrology $73,207-220$.

Ranalli, G., 1997. Rheology of the lithosphere in space and time. In: Burg, J.P., Ford, M., Orogeny Through Time. Geological Society Special Publications 121, 19-37.

Ren, J., Tamaki, K., Li, S., Junxia, Z., 2002. Late Mesozoic and Cenozoic rifting and its dynamic setting in Eastern China and adjacent areas. Tectonophysics 344, 175-205. 
Rey, P.F., Teyssier, C., Whitney, D.L., 2009a. Extension rates, crustal melting, and core complex dynamics. Geology 37, 391-394.

Rey, P.F., Teyssier, C., Whitney, D.L., 2009b. The role of partial melting and extensional strain rates in the development of metamorphic core complexes. Tectonophysics 477, 135144.

Rey, P.F., Müller, R.D., 2010. Fragmentation of active continental plate margins owing to the buoyancy of the mantle wedge. Nature Geosciences 3, 257-261.

Rey, P.F., Teyssier, C., Kruckenberg, S.C., Whitney, D.L., 2011. Viscous collision in channel explains double domes in metamorphic core complexes. Geology 39, 387-390.

Reynolds, S.J., Rehrig, W.A., 1980. Mid-Tertiary plutonism and mylonitisation, South Mountains, central Arizona. In: Crittenden, M.C., Coney, J.P., Davis, G.H. (eds), Cordilleran metamorphic core complexes. Geological Society of America Memoir, Boulder, 159-175.

Ring, U., Johnson, C., Hetzel, R., Gessner, K., 2003. Tectonic denudation of a Late Cretaceous-Tertiary collisional belt: regionally symmetric cooling patterns and their relation to extensional faults in the Anatolide belt of western Turkey. Geol. Mag. 140, 421-441.

Ring, U., Collins, A.S., 2005. SHRIMP dating of the syn-tectonic Egrigöz granite: Precise timing of core-complex formation in the Anatolide belt of western Turkey. Journal of Geological Society of London 162, 289-298. 
Rochette, P., Jackson, M., Aubourg, C., 1992. Rock magnetism and the interpretation of anisotropy of magnetic susceptibility. Reviews of Geophysics 30, 209-226.

Rosenbaum, G., Weinberg, R.F., Regenauer-Lieb, K., 2008. The geodynamics of lithospheric extension. Tectonophysics 458, 1-8.

Simpson, C., Wintsch, R.P., 1989. Evidence for deformation-induced K-feldspar replacement by myrmekite. Journal of Metamorphic Geology 7, 267-275.

Sklyarov, E.V., Mazukabzov, A.M., Donskaya, T.V., Doronina, N.A., Shafeev, A.A., 1994. Metamorphic core complexes of the Zagan Range (Transbaikalia). Dokl Earth Sciences 339, 83-86.

Sokoutis, D., Brun, J.P., van den Driessche, J., Pavlides, S., 1993. A major Oligo-Miocene detachment in southern Rhodope controlling north Aegean extension. Journal of Geological Society of London 150, 243-246.

Song, B., Nutman, A.P., Liu, D.Y., Wu, J.S., 1996. 3800 to 2500 Ma crustal evolution in Anshan area of Liaoning Province, Northeast China. Precambrian Research 78, 79-94.

Soula, J.-C., Debat, P., Brusset, S., Bessière, G., Christophoul, F., Deramond, J., 2001. Thrust-related, diapiric and extensional doming in a frontal orogenic wedge: example of the Montagne Noire, southern French Hercynian belt. Journal of Structural Geology 23, $1677-$ 1699. 
Sullivan, W.A., Snoke, A.W., 2007. Comparative anatomy of core-complex development in the northeastern Great Basin, U.S.A. Rocky Mountain Geology 42, 1-29.

Talbot, J.Y., Martelet, G., Courrioux, G., Chen, Y., Faure, M., 2004. Emplacement in an extensional setting of the Mont Lozère-Borne granitic complex (SE France) inferred from comprehensive AMS, structural and gravity studies. Journal of Structural Geology 26, 11-28.

Tarling, D.H., Hrouda, F., 1993. The magnetic anisotropy of rocks. Chapman and Hall, 215 p.

Tera, F., Wasserburg, G.J., 1972. U-Th-Pb systematics in three Apollo 14 basalts and the problem of initial $\mathrm{Pb}$ in lunar rocks. Earth Planetary Sciences Letters 14, 281-304.

Teyssier, C., Whitney, D.L., 2002. Gneiss domes and orogeny. Geology 30, 1139-1142.

Teyssier, C., Ferré, E.C., Whitney, D.L., Norlander, B., Vanderhaeghe, O., Parkinson, D., 2005. Flow of partially molten crust and origin of detachments during collapse of the Cordilleran orogen. In Bruhn, D., Burlini, L., (Eds.), High-strain zones: Structure and physical properties. Geological Society of London Special Publication 245, 39-64.

Tirel, C., Brun, J.P., Sokoutis, D., 2006. Extension of thickened and hot lithospheres: Inferences from laboratory modeling. Tectonics 25, TC1005, doi:10.1029/2005TC001804.

Tirel, C., Brun, J.P., Burov, E., 2008. Dynamics and structural development of metamorphic core complexes. Journal of Geophysical Research 113, B04403, Tectonies 113. doi:10.1029/2005JB003694. 
Van der Molen, I., Paterson, M.S., 1979. Experimental deformation of partially-melted granite. Contributions to mineralogy and petrology 70, 299-318.

Van Den Driessche, J. and Brun, J.P., 1992. Tectonic evolution of the Montagne Noire (French Massif Central): a model of extensional dome. Geodinamica Acta 5, 85-99.

Vanderhaeghe, O., Teyssier, C., 1997. Formation of the Shuswap metamorphic core complex during late-orogenic collapse of the Canadian Cordillera: role of ductile thinning and partial melting of the mid- to lower crust. Geodinamica Acta 10, 41-58.

Vanderhaeghe, O., Teyssier, C., Wysoczanski, R., 1999. Structural and geochronologic constraints on the role of partial melting during the formation of the Shuswap metamorphic core complex at the latitude of the Thor-Odin dome, British Columbia. Canadian Journal of Earth Sciences 36, 917-943.

Vanderhaeghe, O., Teyssier, O., McDougall, I., Dunalp, W.J., 2003. Cooling and exhumation of the Shuswap metamorphic core complex constrained by ${ }^{40} \mathrm{Ar} /{ }^{39} \mathrm{Ar}$ thermochronology. Geological Society of America Bulletin 115, 200-216.

Vernon, R.H., 2000. Review of microstructural evidence of magmatic and solid-state flow. Electronic Geosciences 5. ISSN1436-2511.

Wang, L.G., Qiu, Y.M., McNaughton, N.J., Groves, D.I., Luo, Z.K., Huang, J.Z., Miao, L.C., Liu, Y.K., 1998. Constraints on crustal evolution and gold metallogeny in the Northwestern 
Jiaodong Peninsula, China, from SHRIMP U-Pb zircon studies of granitoids. Ore Geology Reviews 13, 275-291.

Watson, M.P., Hayward, A.B., Parkinson, D.N., Zhang, Z.M., 1987. Plate tectonic history, basin development and petroleum source rock deposition onshore China. Marine Petroleum Geology 4, 205-225.

Wawrzenitz, N., Krohe, A., 1998. Exhumation and doming of the Thasos metamorphic core complex (S Rhodope, Greece): structural and geochronological constraints. Tectonophysics $285,301-332$.

Webb, L.E., Graham, S.A., Johnson, C.L., Badarch, G., Hendrix, S., 1999. Occurrence, age, and implications of the Yagan-Onch Hayrhan metamorphic core complex, southern Mongolia. Geology 27, 143-146.

Wernicke, B., 1981. Low-angle normal faults in the Basin and Range Province: nappe tectonics in an extending orogen. Nature 291, 645-648.

Wu, F.Y., Jahn, B.M., Wilde, S., Sun, D.Y., 2000. Phanerozoic crustal growth: U-Pb and Sr$\mathrm{Nd}$ isotopic evidence from the granites in northeastern China. Tectonophysics 328, 89-113.

Wu, F.Y., Lin, J.Q., Wilde, S.A., Sun, D.Y., Yang, J.H., 2005a. Nature and significance of the Early Cretaceous giant igneous event in eastern China. Earth Planetary Science Letters 233, 103-119. 
Wu, F.Y., Yang, J.H., Wilde, S.A., Zhang, X.O., 2005b. Geochronology, petrogenesis and tectonic implications of Jurassic granites in the Liaodong Peninsula, NE China. Chemical geology 221, 127-156.

Wu, F.Y., Han, R.H., Yang, J.H., Wilde, S.A., Zhai, M.G., Park, S.C., 2007. Initial constraints on the timing of granitic magmatism in North Korea using U-Pb zircon geochronology. Chemical Geology 238, 232-248.

Xie, L.W., Zhang, Y.B., Zhang, Y.H., Sun, J.F., Wu, F.Y., 2008. In situ simultaneous determination of trace elements, $\mathrm{U}-\mathrm{Pb}$ and $\mathrm{Lu}-\mathrm{Hf}$ isotopes in zircon and baddeleyite. Chinese Science Bulletin 53, 1565-1573.

Xu, Z.Q., Li, H., Wang, Z., Li, D., 1991. Crustal contraction and extension in Southern Liaoning. Geological Review 37, 193-202 (in Chinese).

Yang, J.H., Wu, F.Y., Chung, S.L., Wilde, S.A., Chu, M.F., 2004. Multiple sources for the origin of granites: Geochemical and $\mathrm{Nd} / \mathrm{Sr}$ isotopic evidence from the Gudaoling granite and its mafic enclaves, northeast China. Geochimica et Cosmochimica Acta 68, 4469-4483.

Yang, J.H., Wu, F.Y., Wilde, S.A., Xie, L.W., Yang, Y.H., Liu, X.M., 2007a. Tracing magma mixing in granite genesis: in situ U-Pb dating and Hf-isotope analysis of zircons. Contrib. Mineral. Petrol. 153, 177-190.

Yang, J.H., Wu, F.Y., Chung, S.L., Lo, C.H., Wilde, S.A., Davis, G.A., 2007b. Rapid exhumation and cooling of the Liaonan metamorphic core complex: Inferences from 
${ }^{40} \mathrm{Ar} /{ }^{39} \mathrm{Ar}$ thermochronology and implications for Late Mesozoic extension in the eastern North China Craton. Geological Society of America Bulletin 119, 1405-1414.

Yang, J.H., Wu, F.Y., Wilde, S.A., Liu, X.M., 2007c. Petrogenesis of Late Triassic granitoids and their enclaves with implications for post-collisional lithospheric thinning of the Liaodong Peninsula, North China Craton. Chemical Geology 242, 155-175.

Yang, J.H., Wu, F.Y., Chung, S.L., Lo, C.H., 2008. The extensional geodynamic setting of Early Cretaceous granitic intrusions in the eastern North China Craton: Evidence from laser ${ }^{40} \mathrm{Ar} /{ }^{39} \mathrm{Ar}$ dating of K-bearing minerals. Acta Petrologica Sinica 24, 1175-1184.

Yin, A., Nie, S., 1996. A Phanerozoic palinspastic reconstruction of China and its neighboring regions. In: Yin, A., and Harrison, T. A. (Eds). The tectonic evolution of Asia. New York, Cambridge University Press, 442-485.

Zhai, M.G., Windley, B.F., Kusky, T.M., Meng, Q.R. (Eds), 2007. Mesozoic sub-continental lithospheric thinning under eastern Asia. Geological Society, London, Special Publications 280.

\section{Figure captions:}

Figure 1: (a) Tectonic sketch map of eastern Asia. NCB: North China Block, SCB: South China Block, TLF: Tan-Lu fault. (b) Simplified geological map of Liaodong Peninsula (Liaoning Province). YW: Yiwulüshan dome (Darby et al., 2004), SL: South Liaonan MCC (Liu et al., 2005), LA: Laohushan sheared pluton (Lin et al., 2007), GD: Gudaoling massif, 
YM: Yinmawanshan massif. ${ }^{*} \mathrm{U} / \mathrm{Pb}$ ages on zircon are issued from Darby et al. (2004), Wu et al. (2005a, b), Wu and Yang (2005), Yang et al. (2007a). **Ar/Ar ages on biotite are issued from Yin and Nie (1996), Lin et al. (2007, 2008), Yang et al. (2008).

Figure 2: Structural map of the Gudaoling and Yinmawanshan massifs. U/Pb ages on zircon are from Guo et al. (2004), Wu et al. (2005a, b). Ar/Ar ages on biotite and on hornblende come from Yin and Nie (1996) and Yang et al. (2008). GD: Gudaoling MCC; YM: Yinmawanshan pluton.

Figure 3: Outcrop pictures of the Gudaoling MCC. (a) Migmatites intercalated with amphibolites layers in the core of the dome, (b) Early Cretaceous monzogranite intruded into migmatites, (c) anatectic monzogranite in the core of the dome, (d) drag folds in migmatites on the western border of the dome, (e) mylonites characterised by a top-to-the east shearing, (f) diorite with development of shear bands indicating a top-to-the east sense of shear, $(\mathrm{g})$ landscape view of the Gudaoling detachment fault (GDF), and (h) thin-section picture of a muscovite-fish indicating a top-to-the E kinematic.

Figure 4: (a) and (b) Geological cross-sections in the Gudaoling dome. (c) Map showing positions of cross-sections.

Figure 5: (a) Tectonic breccias from the GDF at the base of the Cretaceous supradetachement basin. (b) Red sandstone strata $(\mathrm{S} 0=\mathrm{N} 35 \mathrm{E} 30 \mathrm{~W})$ in the Cretaceous Wanfu supradetachment basin associated with (c) volcanic breccia. (d) Panorama showing peaks made of E-dipping volcanic breccias. 
Figure 6: (a) Geological cross-section within the Yinmawanshan pluton (location is precised in Fig. 4). Outcrop photographies in the Yinmawanshan massif. (b) Isotropic porphyric Yinmawanshan granite, (c) intrusive relationship between Yinmawanshan granite and Archaean basement, (d) C/S mylonite indicating a top-to-N100 sense of shear, and (e) breccias including mylonitic clasts.

Figure 7: Zoom map on the western border of the Yinmawanshan pluton. Legend is the same than in Figure 2.

Figure 8: Microphotographies of microstructures present in both Gudaoling MCC and Yinmawanshan pluton. (a) and (b) magmatic microstructure with euhedral crystals without internal deformation; (c) and (d) weak solid-state fabric illustrated by quartz grains which are lobate or slightly serrated and presenting chess-board structure; (e) and (f) moderate solidstate fabric woth quartz grains which appear slightly dynamically recrystallised; (g) and (h) intense solid-state fabric shown by quartz-feldspar mylonite with strongly dynamically recrystallised quartz grains. Kfs: potassic feldspar, pl: plagioclase, qz: quartz, bi: biotite, am: amphibole. Left column and right one corresponds to microstructures recognized in the Gudaoling MCC and Yinmawanshan pluton, respectively.

Figure 9: Distribution map of the different types of microstructures in the Gudaoling MCC and Yinmawanshan pluton.

Figure 10: Histogram of bulk magnetic susceptibility $\mathrm{K}_{\mathrm{m}}$. 
Figure 11: Magnetic mineralogy investigations measurements for granitic rocks in the Gudaoling MCC and Yinmawanshan pluton. (a) to (c) Hysteresis loops. (d) to (f) Isothermic remanent magnetization. (g) to (i) Thermomagnetic measurements where black and grey curves indicates heating and cooling stages, respectively. (j) Backscattered electron images of two magnetites from granitic rocks of both massifs.

Figure 12: AMS scalar parameters for cores issued from the Gudaoling MCC and Yinmawanshan pluton. (a) $\mathrm{T}$ (shape parameter) vs. $\mathrm{P}_{\mathrm{J}}$ (corrected anisotropy degree), (b) $\mathrm{T} v s$. $\mathrm{K}_{\mathrm{m}}$ (mean bulk magnetic susceptibility in $10^{-6} \mathrm{SI}$ ) and (c) $\mathrm{P}_{\mathrm{J}} v s . \mathrm{K}_{\mathrm{m}}$. The calculations of $\mathrm{T}$ and $\mathrm{P}_{\mathrm{J}}$ can be found in Jelinek (1981).

Figure 13: (a) Map of localisation of AMS sampling sites for Gudaoling MCC and Yinmawanshan pluton. Equal-area projection of AMS results of each site for (b) Gudaoling MCC and (c) Yinmawanshan pluton. Squares and circles stand for $\mathrm{K}_{1}$ (magnetic lineation) and $\mathrm{K}_{3}$ (pole of magnetic foliation), respectively. Small grey dots and larger black ones represent individual specimen and site-mean direction, respectively. Confidence ellipses at 95\% level are drawn around site-mean direction.

Figure 14: Magnetic fabric maps of the Gudaoling MCC and Yinmawanshan pluton. (a) and (b) present magnetic foliation and lineation maps, respectively. Equal-area projections (lower hemisphere) show the density contours of individual AMS axes for Gudaoling MCC (GD) and Yinmawanshan pluton (YMW). Isocontour range for Gudaoling massif is $2 \%$ and $1 \%$ for Yinmawanshan massif ones. Legend is the same than in Figure 2. 
Figure 15: (a) Foliation trajectories map for Gudaoling MCC and Yinmawanshan pluton. (b) Field strain intensity measurements on the Gudaoling and Yinmawanshan massifs. Locations of the measurements are displayed with individual values $(\mathrm{n}=258)$ by which the contours map is built up with kriging interpolation. GDF = Gudaoling detachment fault.

Figure 16: (a) Outcrop of dated migmatite located within the dome centre with its interpretation drawing; (b) Tera and Wasserburg (1972) Concordia diagram for 09-114 sample. Examples of CL images of zircon are shown with location of analytical points. The diameter of ablation pit is ca. $30 \mu \mathrm{m}$. Data-point error ellipses are plotted as $2 \sigma$.

Figure 17: (a) and (c) Reconstructed cooling histories of both South Liaodong and Gudaoling MCCs, combining Ar/Ar on synkinematic minerals and $\mathrm{U} / \mathrm{Pb}$ on zircon datations. am: amphibole, bi: biotite, kf: potassic feldspar. (b) Serie of sections showing the evolution of a MCC at the crustal-scale whith both main phases of crustal necking and dome amplification and exhumation (modified from Tirel et al., 2008), associated with corresponding field photographies.

Figure 18: (a) Tectonic map showing the South Liaodong MCC (Liu et al., 2005; Lin and Wang, 2006; Lin et al., 2008); the Gudaoling MCC and the Yinmawanshan synkinematic pluton (this study). (b) and (c) present cross-sections within Gudaoling and South Liaonan MCCs, respectively.

\section{Tables:}


Table 1: The results of AMS measurements for the Gudaoling massif. n: number of specimens. Dec, Inc, $\alpha_{95 \min }, \alpha_{95 \max }$ are declination, inclination, Jelinek's statistic confidence at 95\% level (Jelinek, 1981) in degrees, respectively. $\mathrm{P}_{\mathrm{J}}$ : Corrected anisotropy degree, T: Anisotropy shape parameter (Jelinek, 1981), and $\mathrm{K}_{\mathrm{m}}$ : Mean bulk magnetic susceptibility.

Table 2: The results of AMS measurements for the Yinmawanshan pluton. n: number of specimens. Dec, Inc, $\alpha_{95 \min }, \alpha_{95 \max }$ are declination, inclination, Jelinek's statistic confidence at 95\% level (Jelinek, 1981) in degrees, respectively. $\mathrm{P}_{\mathrm{J}}$ : Corrected anisotropy degree, $\mathrm{T}$ : Anisotropy shape parameter (Jelinek, 1981), and $\mathrm{K}_{\mathrm{m}}$ : Mean bulk magnetic susceptibility.

Table 3: Semi-variogram models used for the ordinary kriging interpolation of the strain field intensity measured within the Gudaoling dome and the Yinmawanshan pluton.

Table 4: Details of $\mathrm{U} / \mathrm{Pb}$ analyses on zircons of the migmatites within the Gudaoling dome after reduction and common $\mathrm{Pb}$ corrections. Uncertainties are at $1 \sigma$, including the error related to calibration. 


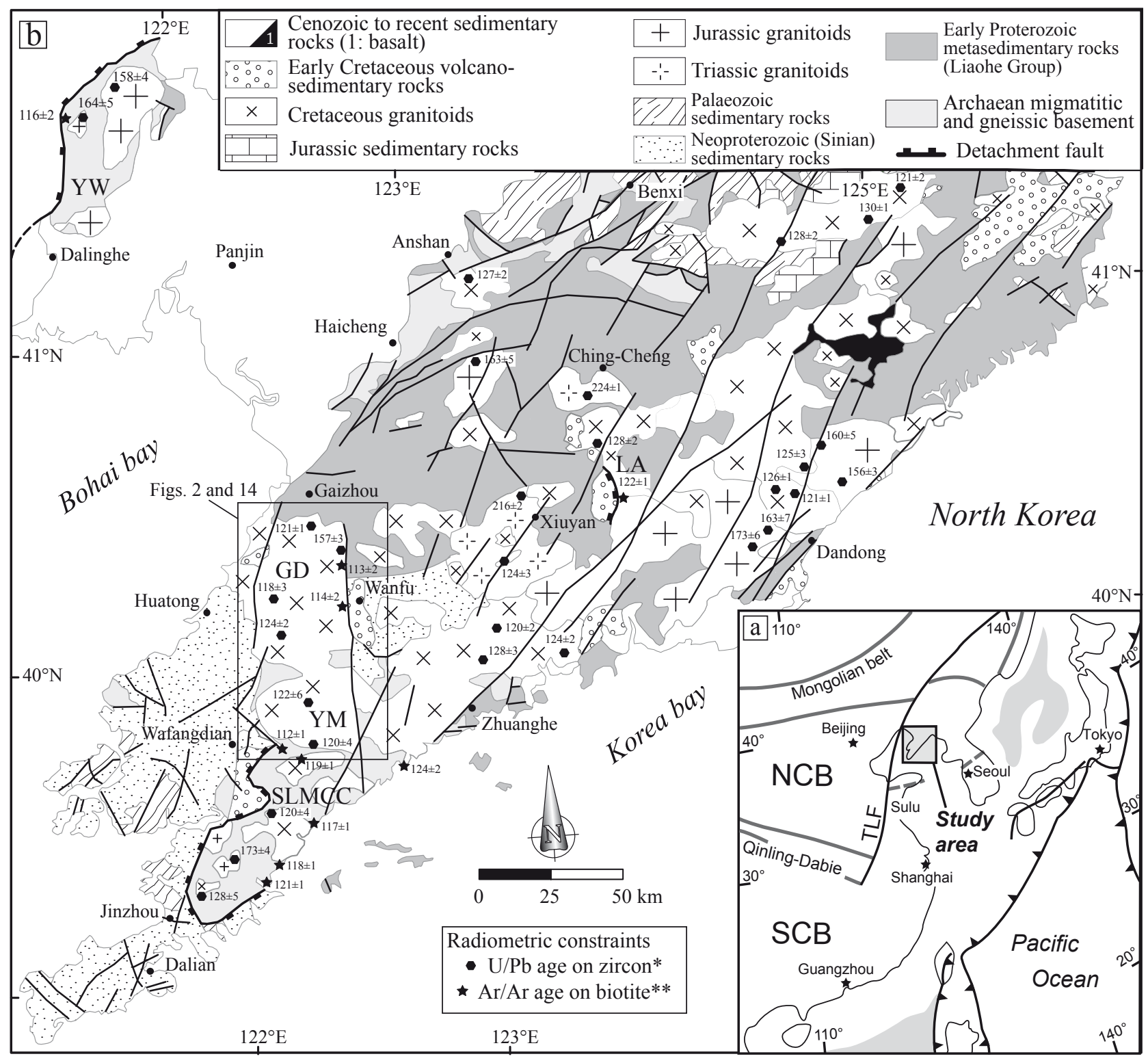

Figure 1 


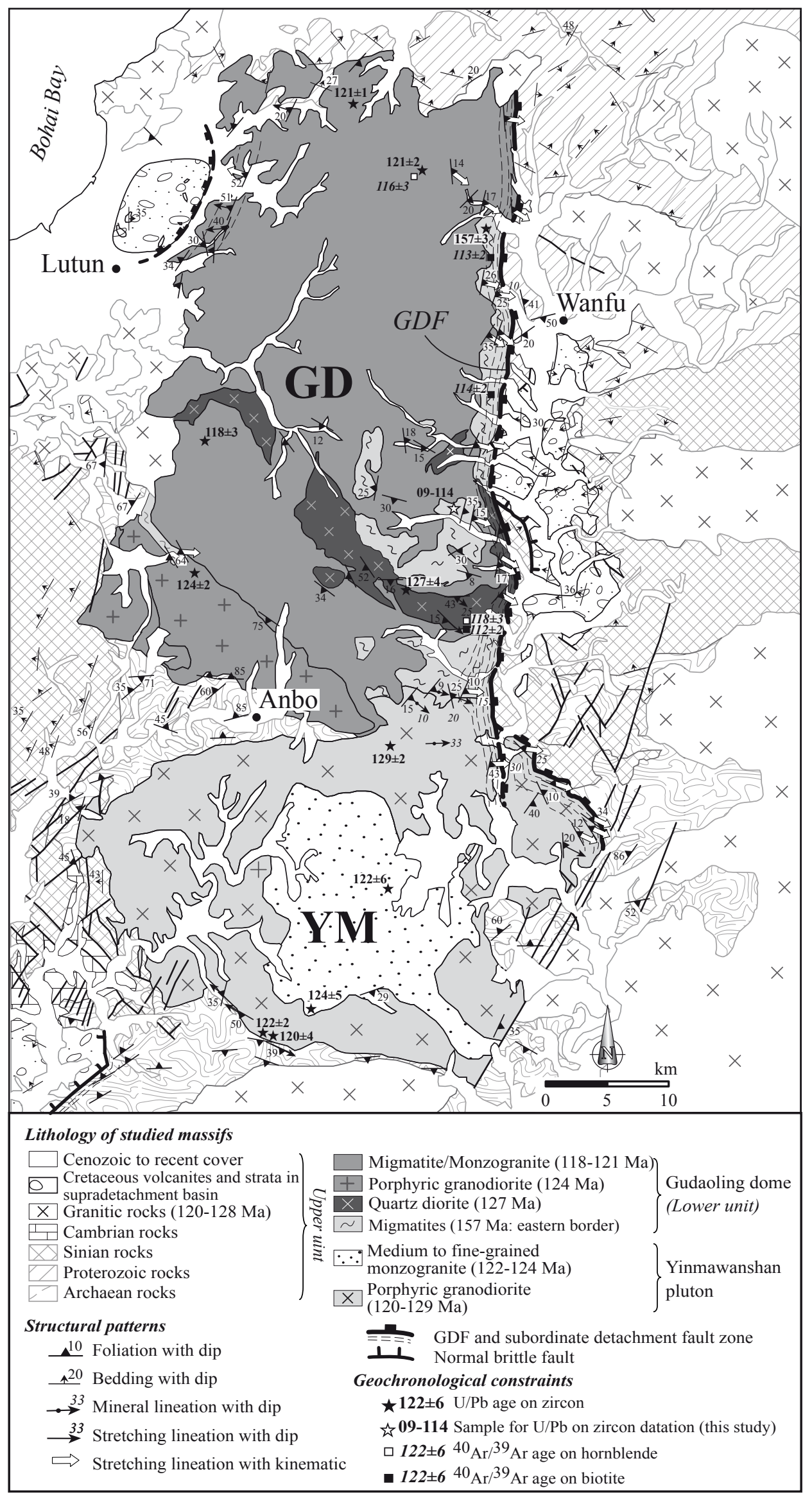

Figure 2 

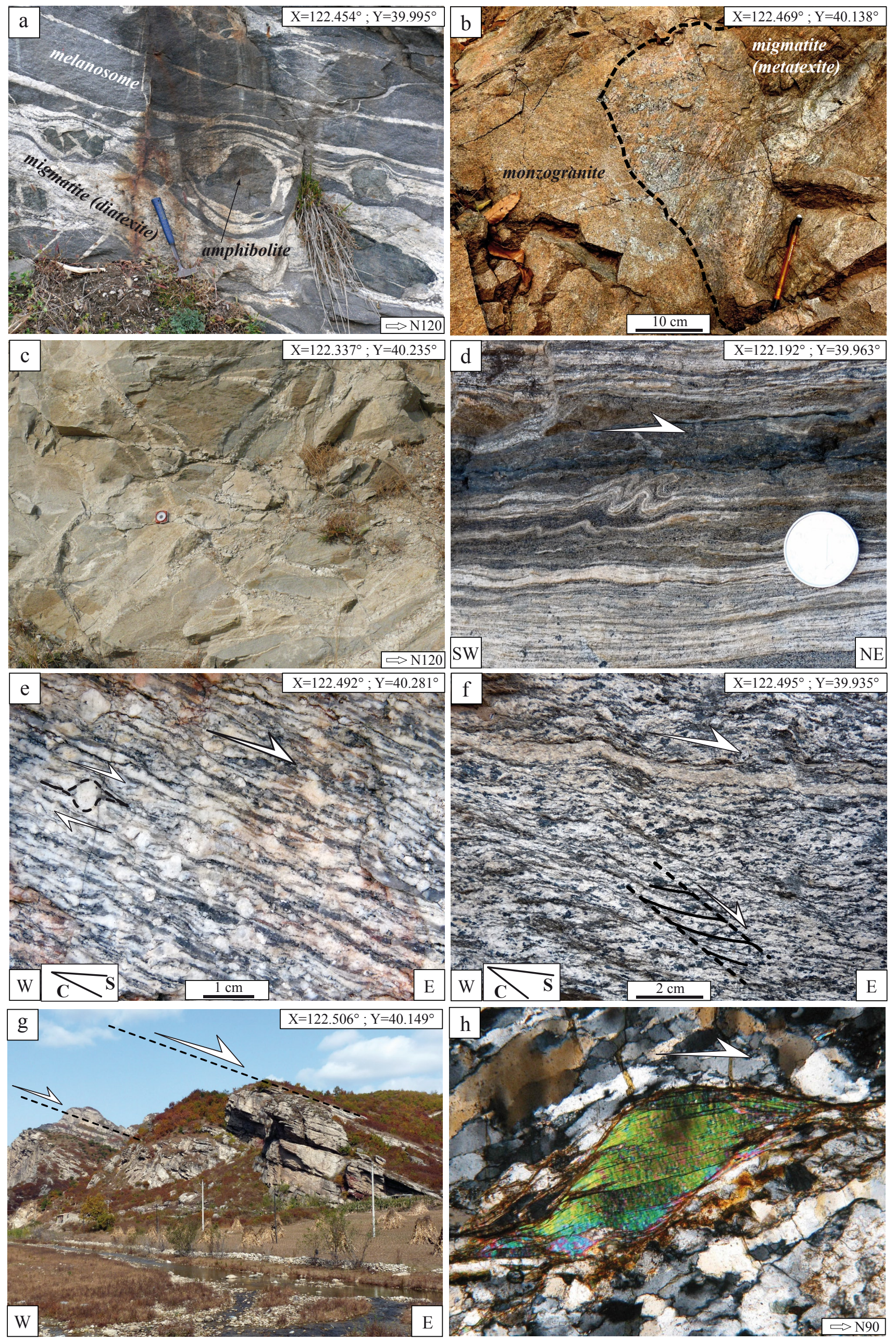

Figure 3 


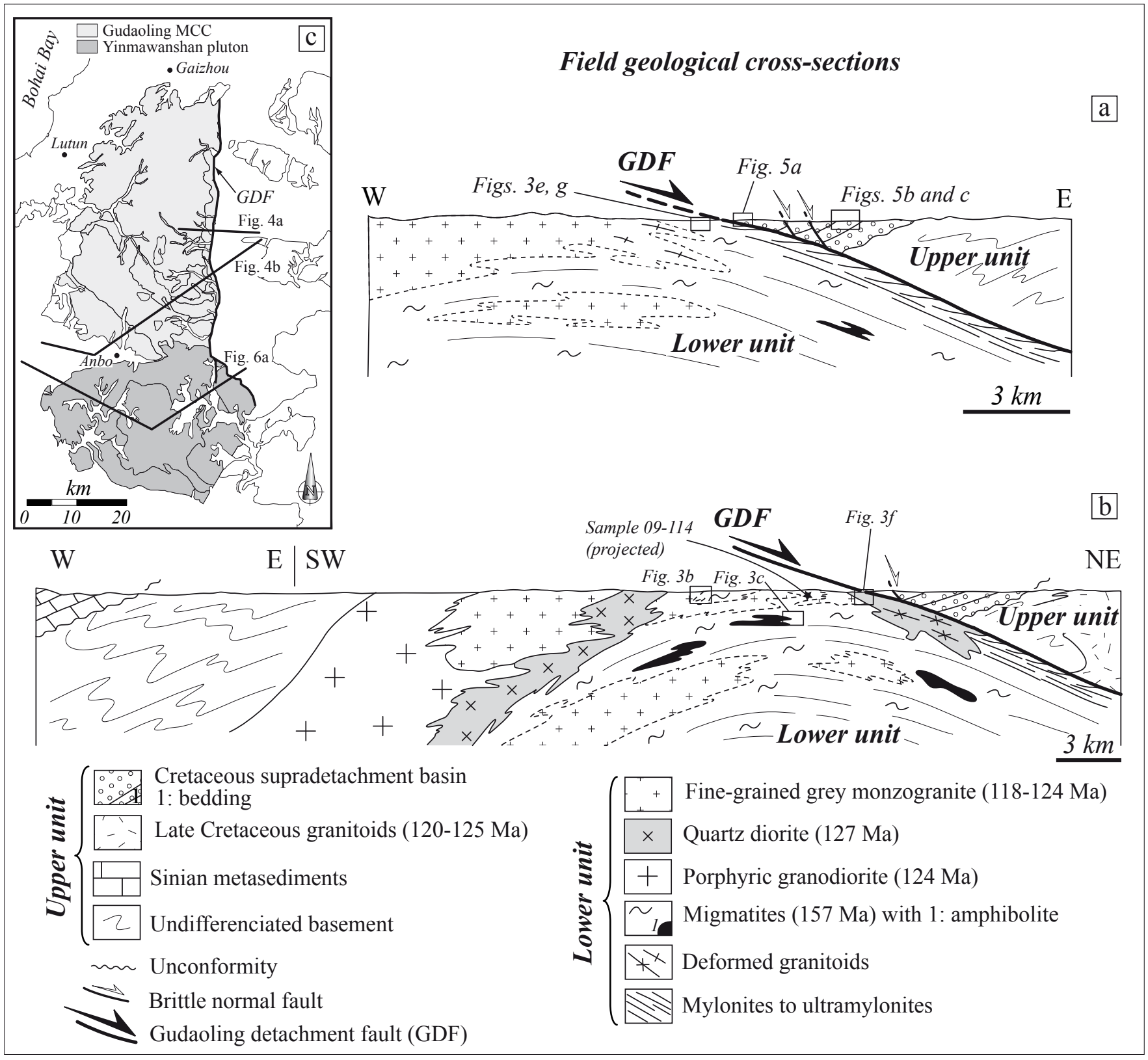

Figure 4 

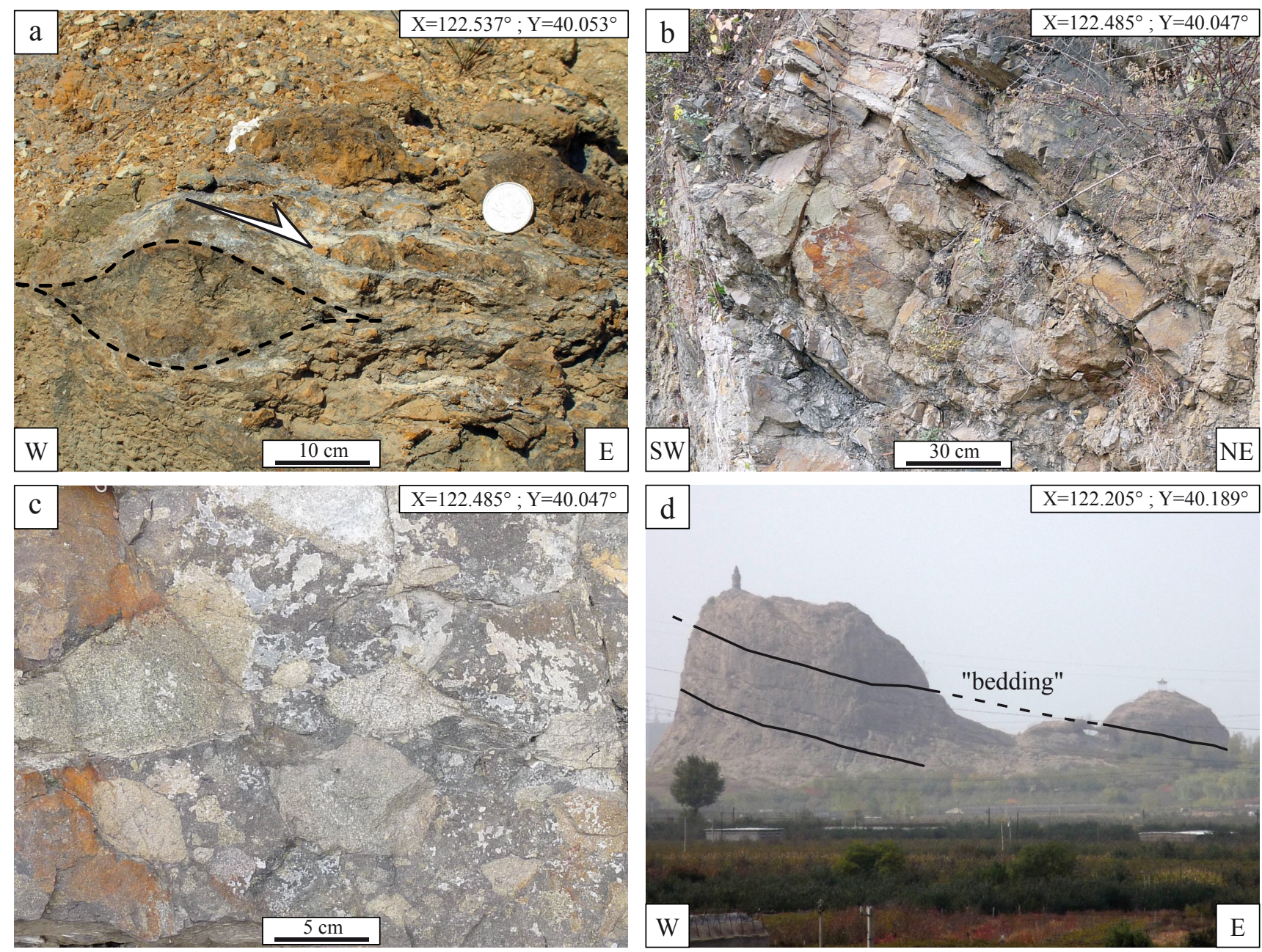

Figure 5 

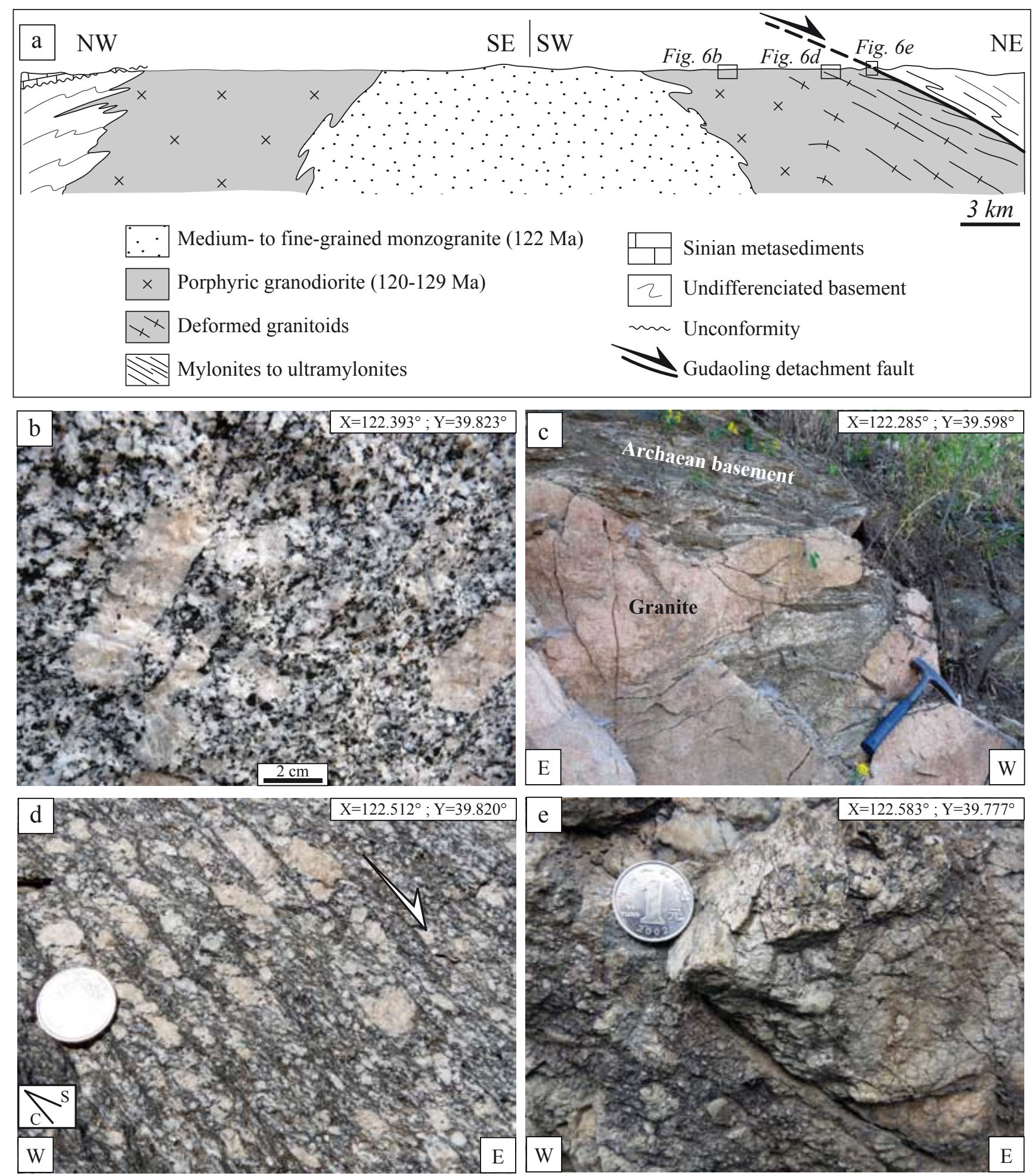

Figure 6 


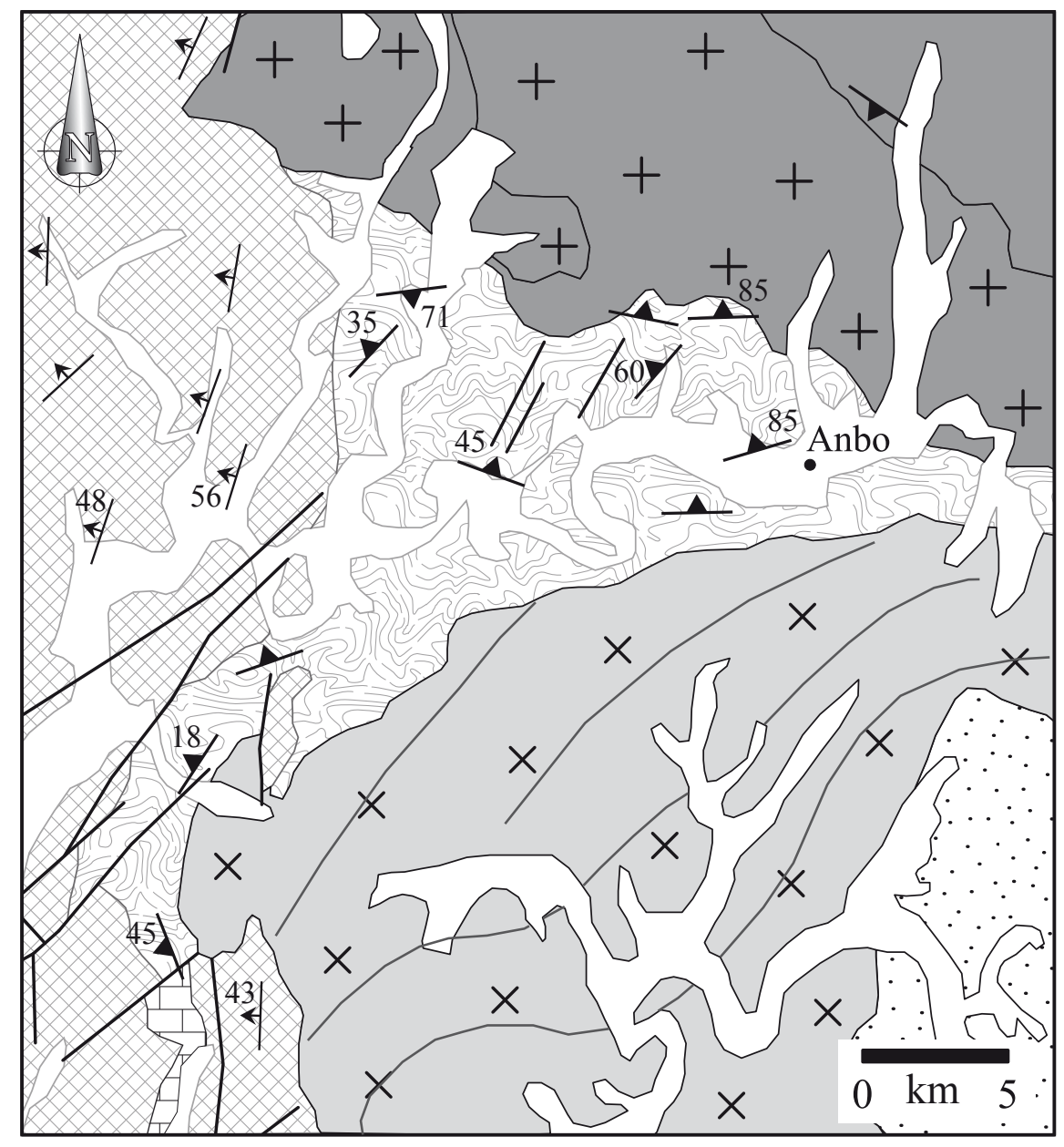

Figure 7 

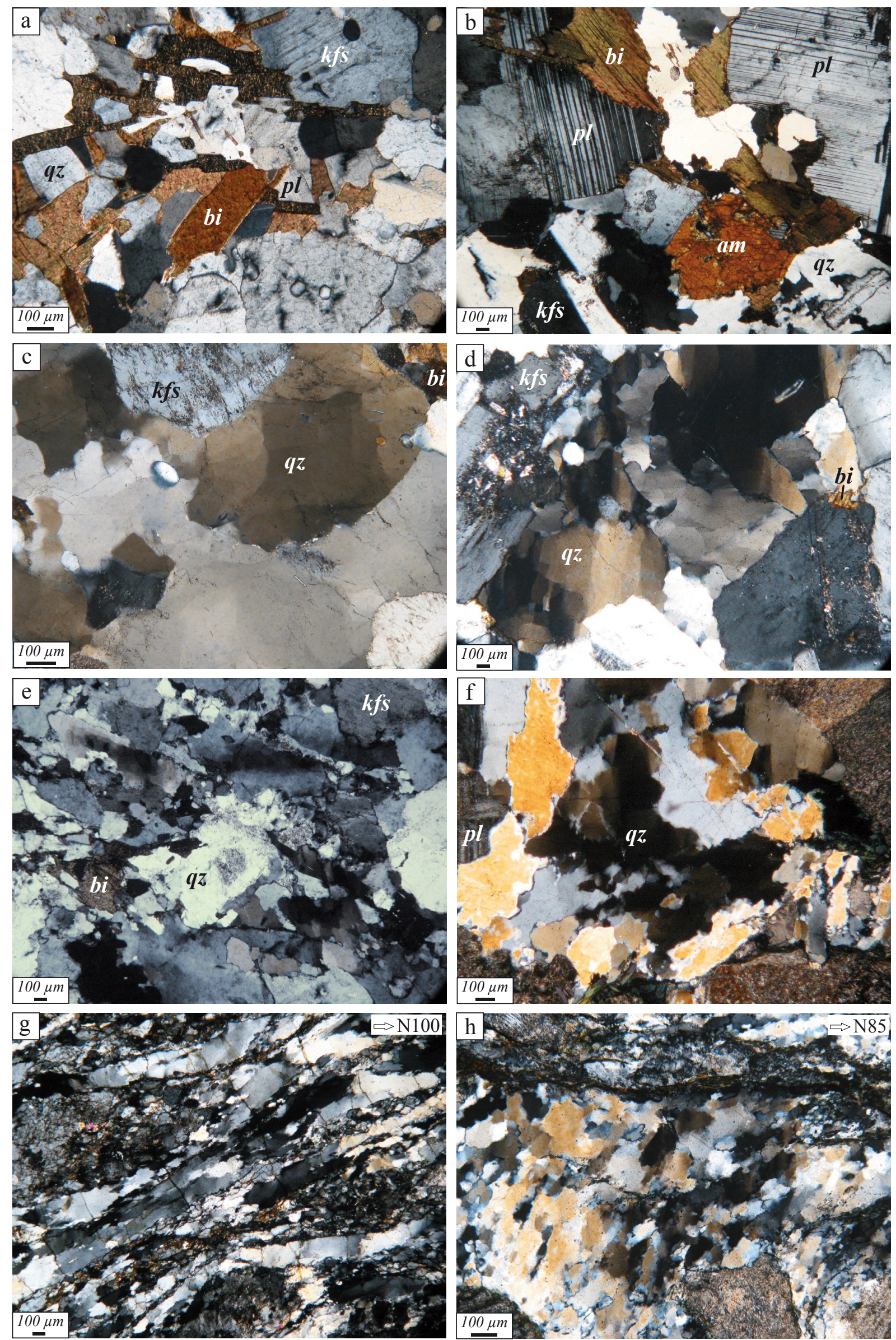

Figure 8 


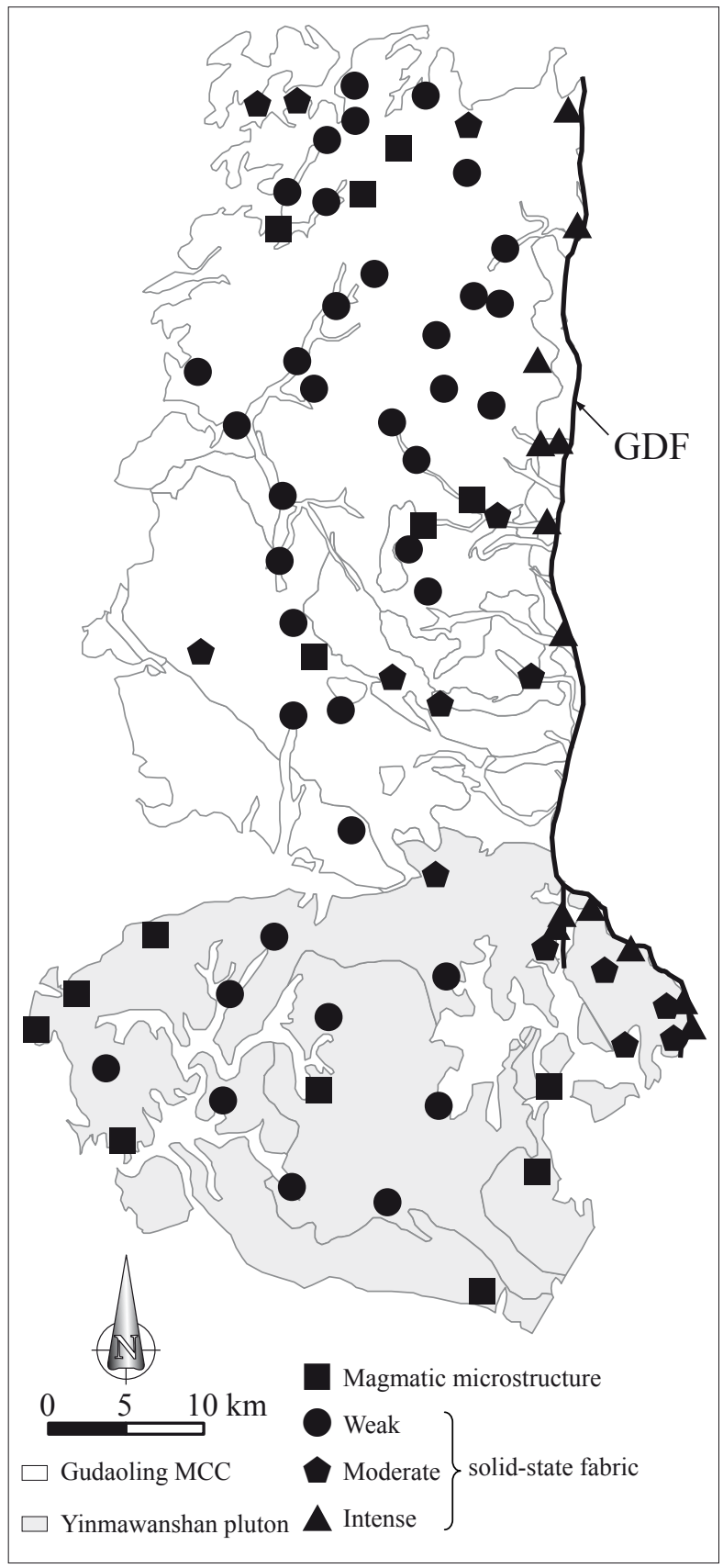

Figure 9 


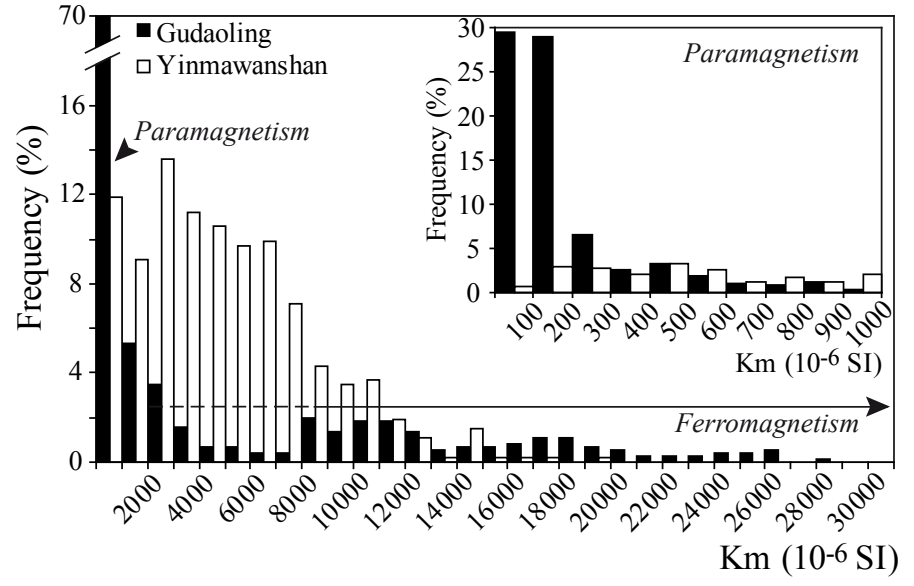

Figure 10 


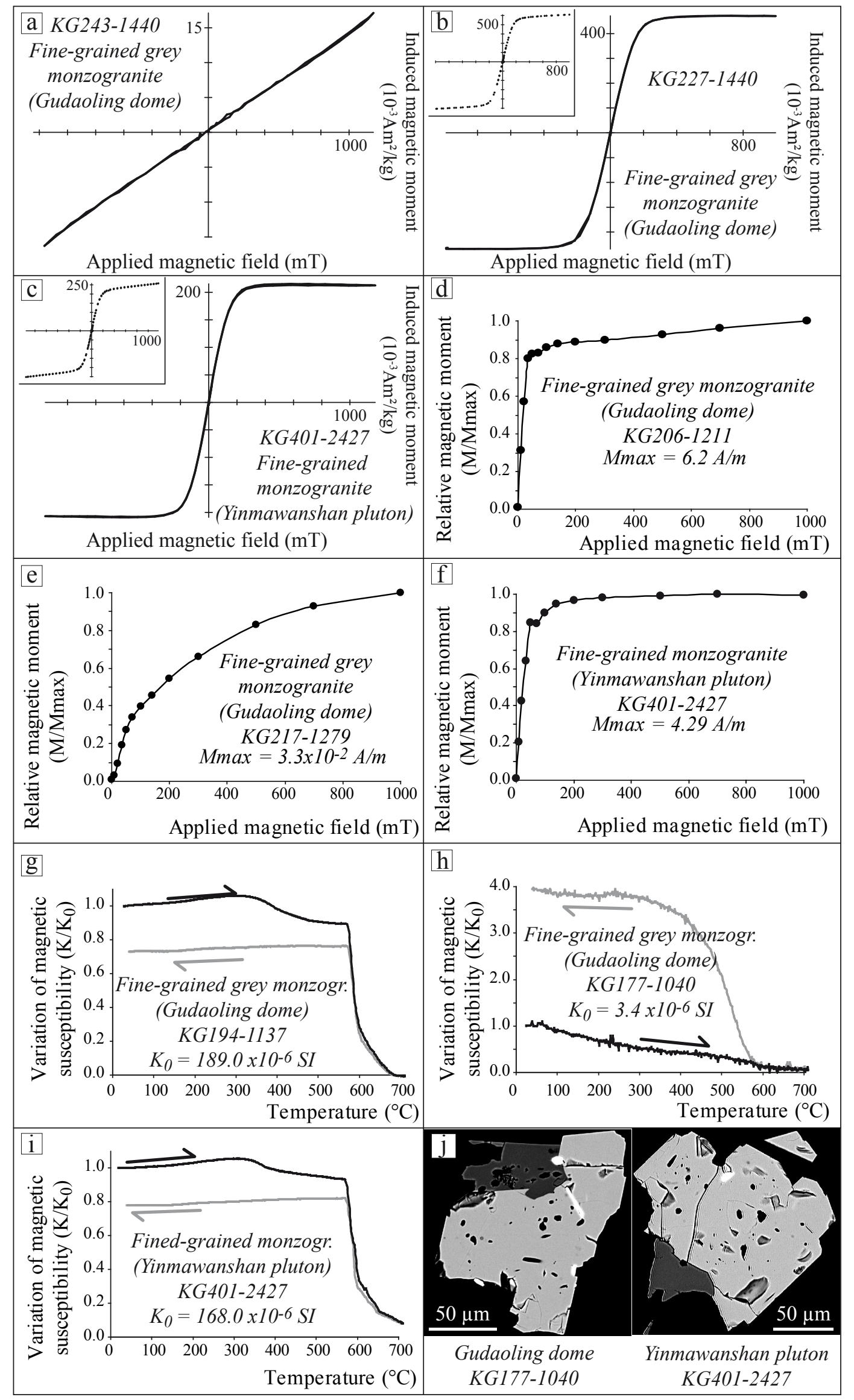

Figure 11 

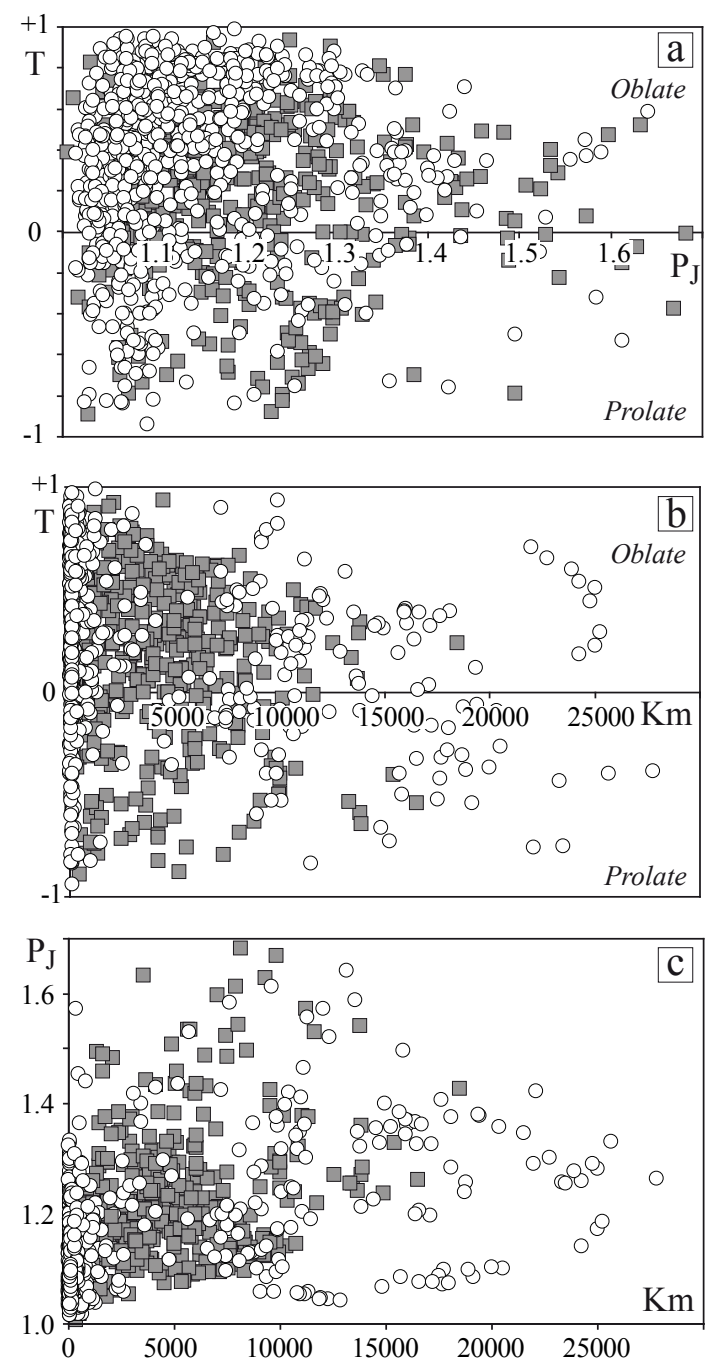

口 Yinmawanshan pluton granitic rocks $(\mathrm{n}=403)$

- Gudaoling dome granitic rocks $(\mathrm{n}=708)$

\section{Figure 12}




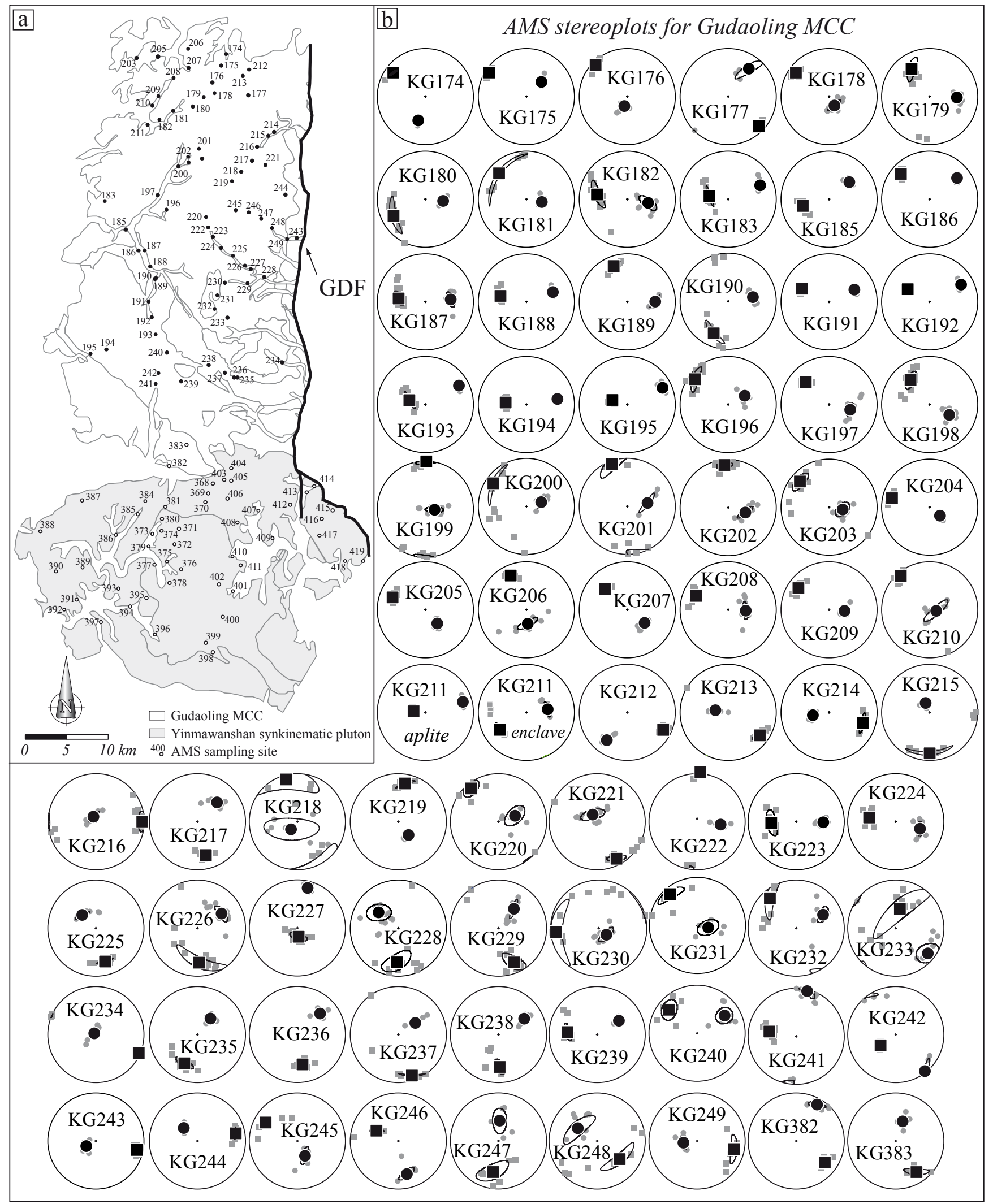

Figure 13 


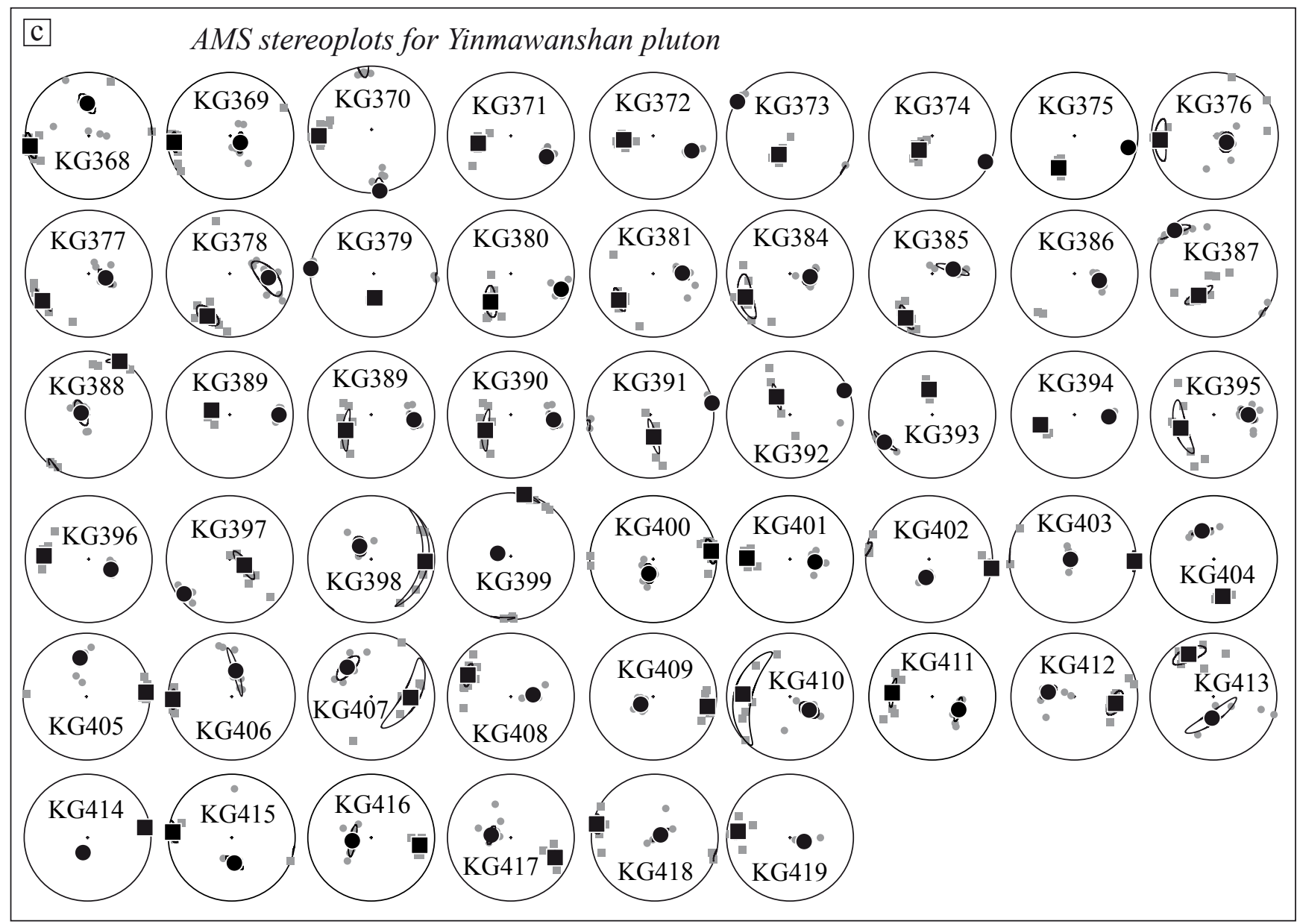

Figure 13 (continued) 


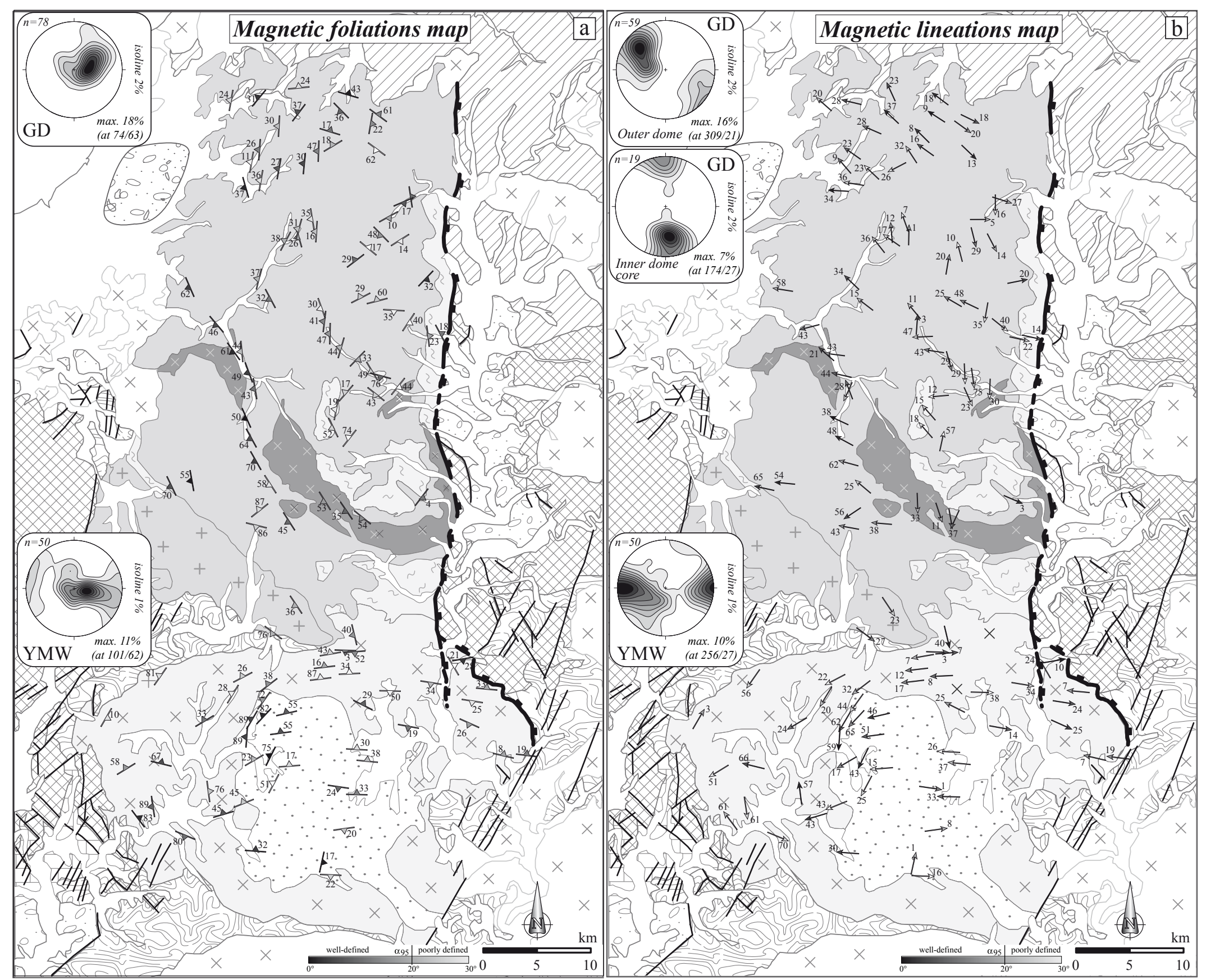

Figure 14 

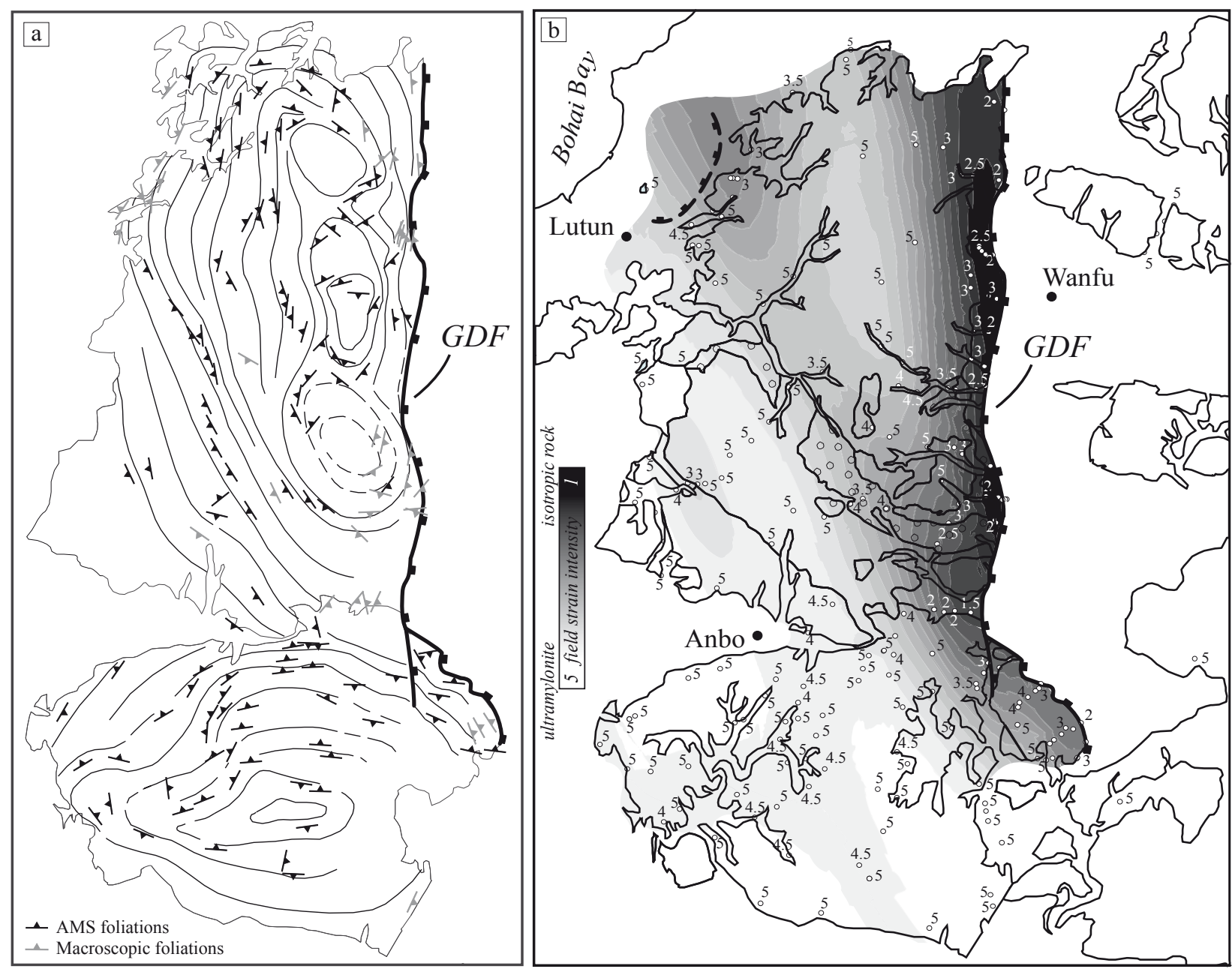

Figure 15 

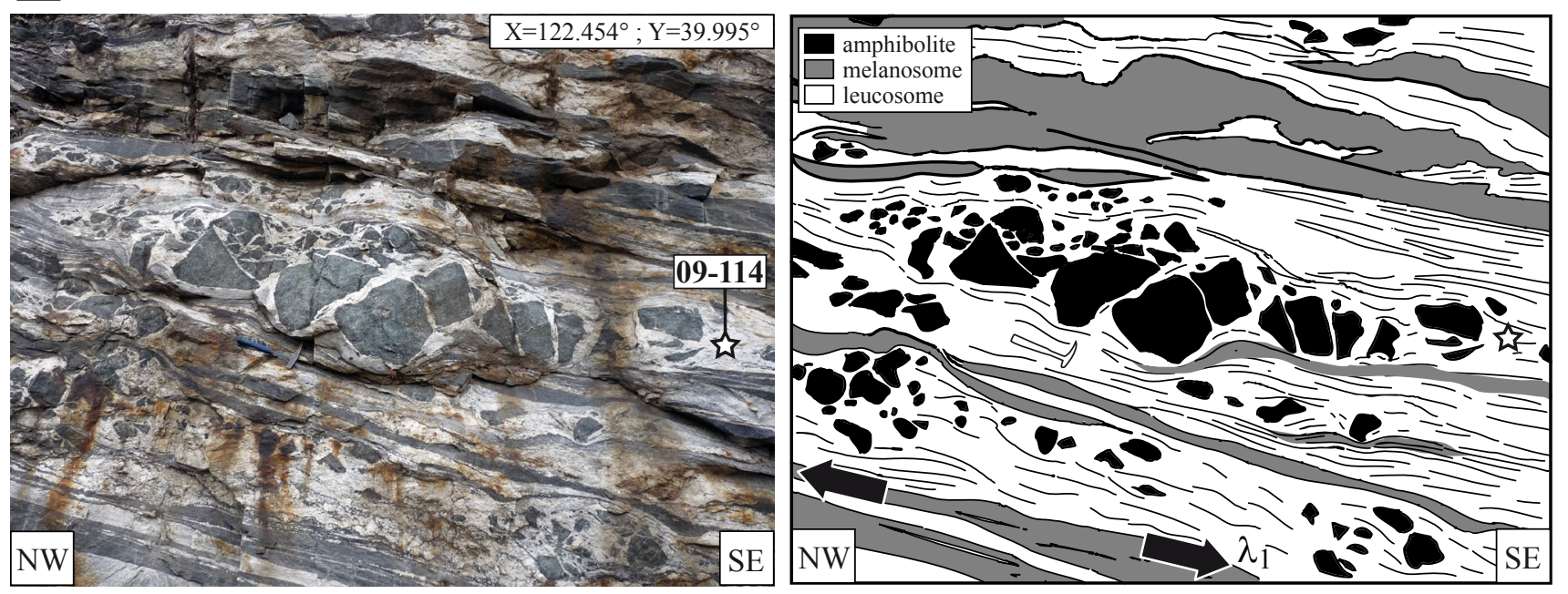

b

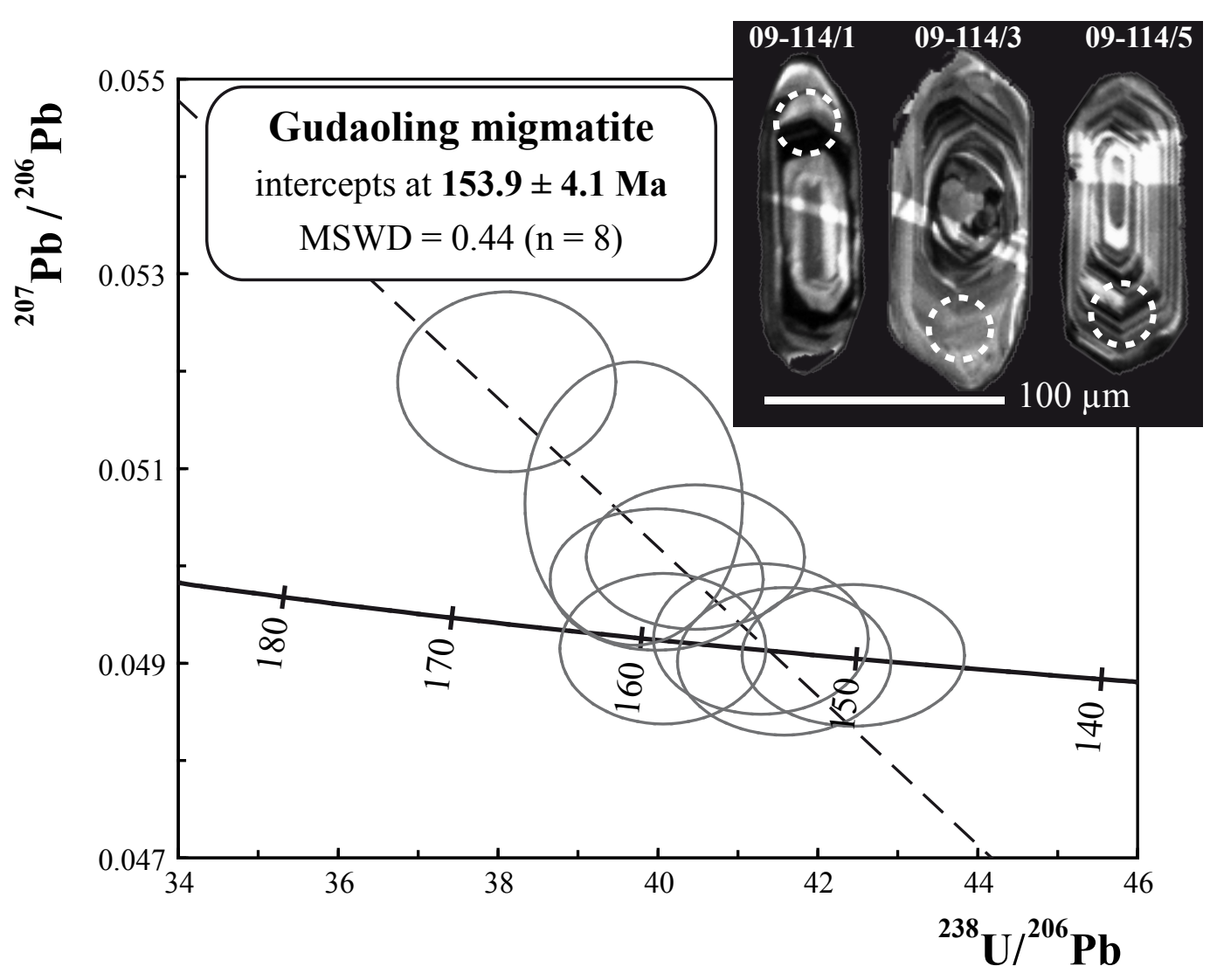

Figure 16 


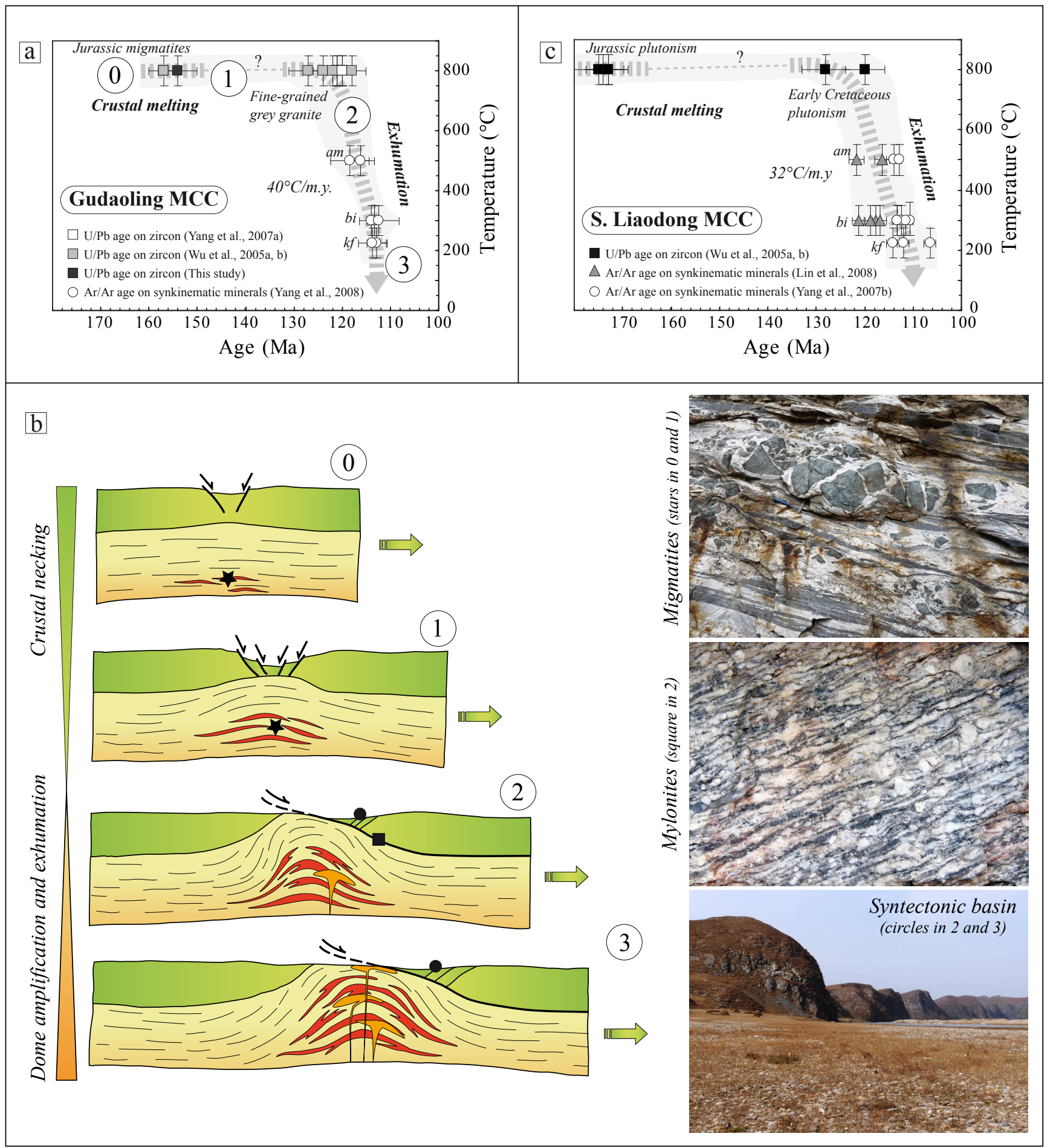

Figure 17 

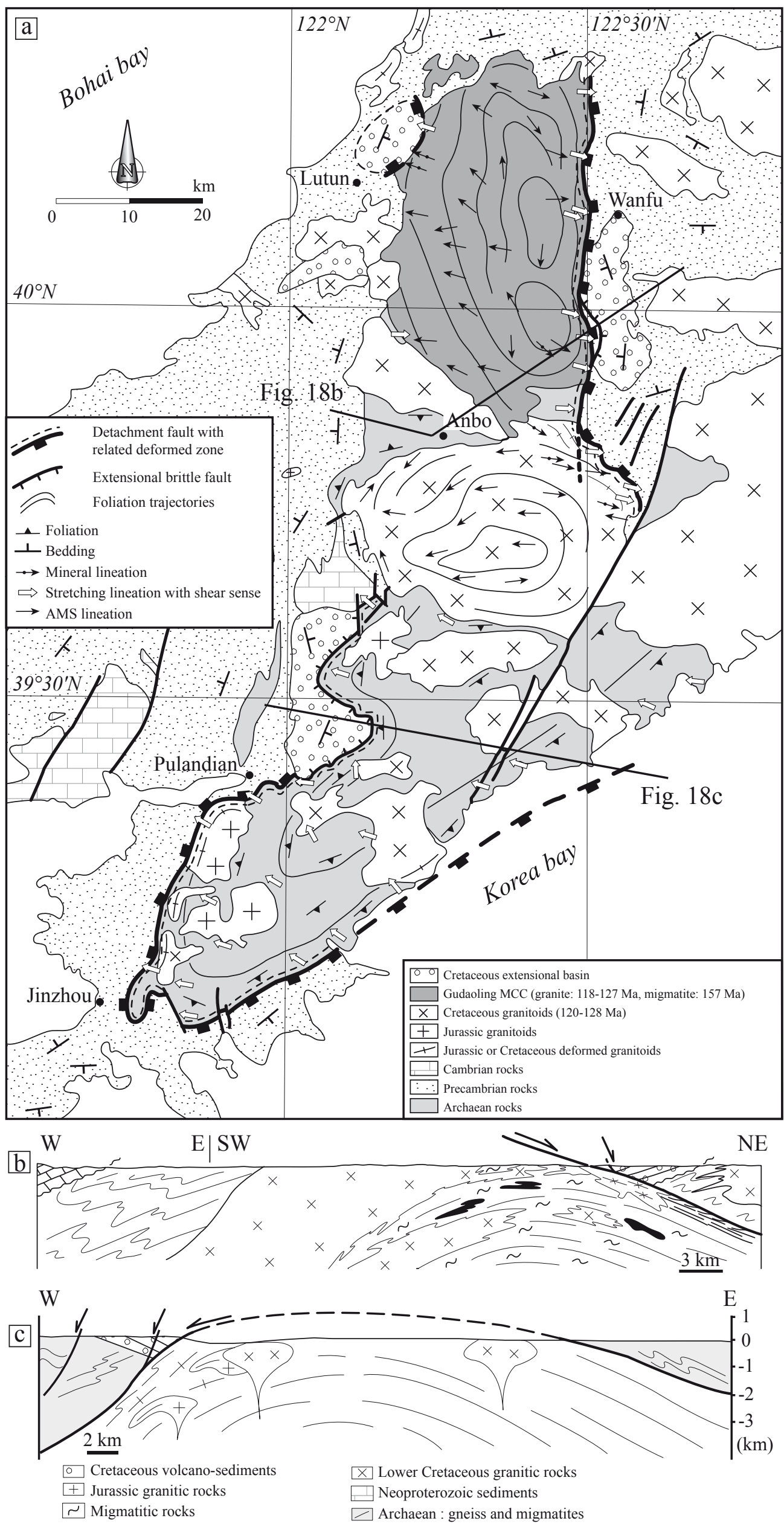

Figure 18 


\begin{tabular}{|c|c|c|c|c|c|c|c|c|c|c|c|c|c|c|}
\hline \multirow[t]{2}{*}{ Site } & \multicolumn{2}{|c|}{ Coordinates } & \multirow[t]{2}{*}{$\mathbf{n}$} & \multirow{2}{*}{$\begin{array}{c}\mathrm{Km} \\
\left(10^{-6} \mathrm{SI}\right) \\
\end{array}$} & \multirow[t]{2}{*}{$\mathbf{P}_{\mathbf{J}}$} & \multirow[t]{2}{*}{$\mathbf{T}$} & \multicolumn{4}{|c|}{$\mathbf{K}_{1}$} & \multicolumn{4}{|c|}{$\mathbf{K}_{\mathbf{3}}$} \\
\hline & $\begin{array}{c}\text { Latitude } \\
\left({ }^{\circ} \mathbf{N}\right)\end{array}$ & $\begin{array}{c}\text { Longitude } \\
\left({ }^{\circ} \mathbf{E}\right)\end{array}$ & & & & & $\mathbf{D}\left({ }^{\circ}\right)$ & $\mathbf{I}\left({ }^{\circ}\right)$ & $\alpha_{95 \max }$ & $\alpha_{95 \min }$ & $\mathbf{D}\left({ }^{\circ}\right)$ & $\mathbf{I}\left({ }^{\circ}\right)$ & $\alpha_{95 \max }$ & $\alpha_{95 \min }$ \\
\hline KG174 & 122.383 & 40.291 & 8 & 7020 & 1.193 & -0.057 & 306.8 & 17.9 & 6.9 & 1.7 & 196.6 & 47.1 & 4.1 & 1.5 \\
\hline KG175 & 122.376 & 40.278 & 8 & 7920 & 1.125 & -0.113 & 303.0 & 9.1 & 4.8 & 1.7 & 45.7 & 54.0 & 7.4 & 2.3 \\
\hline KG176 & 122.363 & 40.260 & 7 & 118 & 1.089 & 0.307 & 314.7 & 7.9 & 7.8 & 1.4 & 197.2 & 73.2 & 6.9 & 3.8 \\
\hline KG177 & 122.415 & 40.246 & 7 & 108 & 1.095 & -0.615 & 133.8 & 13.1 & 6.2 & 1.4 & 36.5 & 28.5 & 30.5 & 5.9 \\
\hline KG178 & 122.367 & 40.248 & 11 & 641 & 1.058 & -0.143 & 305.5 & 16.2 & 6.2 & 4.2 & 149.1 & 72.4 & 13.4 & 4.3 \\
\hline KG179 & 122.352 & 40.244 & 12 & 231 & 1.078 & 0.531 & 326.8 & 31.8 & 21.5 & 6.3 & 91.9 & 42.9 & 8.4 & 4.1 \\
\hline KG180 & 122.336 & 40.233 & 11 & 128 & 1.113 & 0.803 & 242.5 & 26.2 & 28.9 & 5.6 & 95.5 & 59.6 & 6.1 & 2.1 \\
\hline KG181 & 122.309 & 40.229 & 7 & 1320 & 1.078 & 0.412 & 313.4 & 22.8 & 49.4 & 3.6 & 100.2 & 63.3 & 5.7 & 3.8 \\
\hline KG182 & 122.289 & 40.218 & 9 & 166 & 1.046 & 0.160 & 278.8 & 36.3 & 24.6 & 6.1 & 99.9 & 53.7 & 18.5 & 7.4 \\
\hline KG183 & 122.212 & 40.129 & 12 & 131 & 1.093 & 0.693 & 278.8 & 57.6 & 18.5 & 2.5 & 66.6 & 28.2 & 5.5 & 2.5 \\
\hline KG185 & 122.242 & 40.098 & 12 & 168 & 1.068 & 0.576 & 255.6 & 42.9 & 8.3 & 4.3 & 49.8 & 44.1 & 5.6 & 2.7 \\
\hline KG186 & 122.260 & 40.076 & 7 & 465 & 1.083 & 0.465 & 311.4 & 21.4 & 8.3 & 1.1 & 54.1 & 29.3 & 6.4 & 0.8 \\
\hline KG187 & 122.270 & 40.076 & 12 & 132 & 1.114 & 0.507 & 277.2 & 43.3 & 13.5 & 4.9 & 84.6 & 46.0 & 12.8 & 6.2 \\
\hline KG188 & 122.277 & 40.058 & 11 & 150 & 1.119 & 0.760 & 282.9 & 43.9 & 8.8 & 2.9 & 69.8 & 41.0 & 5.2 & 2.7 \\
\hline KG189 & 122.286 & 40.046 & 6 & 86.3 & 1.153 & 0.568 & 339.2 & 21.4 & 11.7 & 1.3 & 89.4 & 41.4 & 13.2 & 1.5 \\
\hline KG190 & 122.284 & 40.045 & 11 & 219 & 1.091 & 0.816 & 204.3 & 27.7 & 23.6 & 4.5 & 80.5 & 46.7 & 8.3 & 2.5 \\
\hline KG191 & 122.275 & 40.020 & 11 & 16100 & 1.367 & 0.354 & 294.9 & 37.6 & 4.6 & 1.7 & 65.9 & 40.4 & 3.1 & 1.1 \\
\hline KG192 & 122.281 & 40.003 & 7 & 9670 & 1.470 & 0.475 & 298.3 & 47.7 & 4.7 & 2.9 & 61.2 & 26.3 & 5.8 & 2.8 \\
\hline KG193 & 122.286 & 39.984 & 11 & 8120 & 1.184 & 0.622 & 285.2 & 61.8 & 17.0 & 3.0 & 60.5 & 20.9 & 4.7 & 3.4 \\
\hline KG194 & 122.216 & 39.967 & 10 & 10600 & 1.368 & 0.250 & 275.5 & 54.3 & 5.3 & 1.5 & 79.9 & 34.7 & 3.8 & 1.4 \\
\hline KG195 & 122.194 & 39.963 & 9 & 17500 & 1.352 & 0.034 & 282.4 & 65.3 & 4.8 & 4.2 & 64.6 & 19.9 & 5.8 & 2.9 \\
\hline KG196 & 122.300 & 40.120 & 10 & 120 & 1.065 & 0.602 & 307.5 & 14.5 & 19.5 & 6.6 & 62.0 & 58.0 & 7.3 & 4.5 \\
\hline KG197 & 122.287 & 40.136 & 8 & 139 & 1.075 & -0.420 & 313.6 & 33.5 & 7.7 & 2.2 & 103.7 & 52.7 & 10.8 & 6.7 \\
\hline KG198 & 122.316 & 40.168 & 11 & 76.7 & 1.060 & 0.672 & 322.0 & 35.6 & 16.1 & 6.4 & 117.9 & 51.9 & 8.8 & 7.7 \\
\hline KG199 & 122.350 & 40.176 & 12 & 105 & 1.030 & 0.247 & 1.1 & 0.7 & 13.2 & 5.5 & 93.6 & 74.4 & 15.1 & 5.5 \\
\hline KG200 & 122.331 & 40.172 & 11 & 92.6 & 1.126 & 0.701 & 305.0 & 17.3 & 32.3 & 3.9 & 74.1 & 63.7 & 11.0 & 4.0 \\
\hline KG201 & 122.345 & 40.187 & 8 & 87.6 & 1.078 & 0.689 & 340.1 & 7.3 & 25.9 & 10.0 & 80.6 & 54.9 & 20.7 & 3.7 \\
\hline KG202 & 122.330 & 40.178 & 11 & 102 & 1.070 & 0.199 & 355.0 & 11.9 & 10.5 & 7.5 & 105.8 & 59.5 & 16.0 & 4.2 \\
\hline KG203 & 122.255 & 40.286 & 11 & 29.8 & 1.062 & 0.112 & 311.4 & 20.3 & 15.7 & 8.9 & 99.8 & 66.5 & 14.5 & 9.2 \\
\hline KG204 & 122.286 & 40.288 & 10 & 149 & 1.242 & 0.773 & 283.3 & 20.6 & 6.7 & 3.3 & 129.6 & 67.2 & 4.8 & 2.6 \\
\hline KG205 & 122.286 & 40.287 & 12 & 70.9 & 1.275 & 0.738 & 290.8 & 27.9 & 5.8 & 3.9 & 140.4 & 58.7 & 6.9 & 2.6 \\
\hline KG206 & 122.329 & 40.296 & 12 & 17800 & 1.085 & -0.390 & 335.4 & 22.7 & 7.7 & 2.3 & 174.4 & 66.2 & 18.9 & 5.4 \\
\hline KG207 & 122.330 & 40.276 & 13 & 192 & 1.142 & 0.564 & 313.3 & 37.1 & 5.2 & 2.4 & 127.0 & 52.7 & 6.6 & 2.2 \\
\hline KG208 & 122.308 & 40.264 & 9 & 117 & 1.155 & -0.204 & 293.5 & 28.4 & 8.2 & 6.4 & 92.9 & 60.0 & 14.6 & 4.6 \\
\hline KG209 & 122.287 & 40.244 & 8 & 58.2 & 1.057 & 0.131 & 305.2 & 23.0 & 8.7 & 4.1 & 94.1 & 63.6 & 7.2 & 4.9 \\
\hline KG210 & 122.278 & 40.234 & 8 & 236 & 1.045 & 0.022 & 319.4 & 8.6 & 10.4 & 3.8 & 99.4 & 78.8 & 26.7 & 6.8 \\
\hline KG211A & 122.272 & 40.213 & 7 & 39.6 & 1.192 & 0.827 & 273.4 & 68.8 & 5.3 & 1.4 & 74.3 & 20.1 & 5.2 & 1.7 \\
\hline $\mathrm{KG} 211 \mathrm{E}$ & 122.272 & 40.213 & 7 & 139 & 1.107 & 0.291 & 236.7 & 34.3 & 12.6 & 2.6 & 81.7 & 53.1 & 12.7 & 3.6 \\
\hline KG212 & 122.416 & 40.274 & 7 & 116 & 1.186 & 0.379 & 116.0 & 18.1 & 7.2 & 4.4 & 216.4 & 29.0 & 9.0 & 3.5 \\
\hline KG213 & 122.407 & 40.267 & 9 & 113 & 1.136 & 0.384 & 125.9 & 19.9 & 12.1 & 5.8 & 279.7 & 68.0 & 10.8 & 2.4 \\
\hline KG214 & 122.452 & 40.206 & 7 & 109 & 1.127 & 0.773 & 107.5 & 26.8 & 15.0 & 4.0 & 261.7 & 60.7 & 6.4 & 3.6 \\
\hline KG215 & 122.444 & 40.202 & 10 & 90.9 & 1.212 & 0.810 & 180.0 & 16.0 & 33.6 & 3.7 & 336.8 & 72.7 & 5.8 & 3.3 \\
\hline KG216 & 122.428 & 40.189 & 10 & 93 & 1.124 & 0.773 & 89.8 & 4.7 & 12.8 & 8.8 & 331.1 & 80.4 & 12.1 & 3.0 \\
\hline KG217 & 122.420 & 40.175 & 12 & 78.5 & 1.045 & -0.088 & 165.8 & 29.1 & 9.5 & 4.1 & 45.5 & 42.3 & 9.8 & 3.7 \\
\hline KG218 & 122.406 & 40.162 & 7 & 29.8 & 1.063 & 0.016 & 345.4 & 10.0 & 49.4 & 19.9 & 219.6 & 73.2 & 48.2 & 18.5 \\
\hline KG219 & 122.393 & 40.152 & 6 & 40 & 1.080 & 0.577 & 9.6 & 20.4 & 16.4 & 2.0 & 142.6 & 61.4 & 7.1 & 3.4 \\
\hline KG220 & 122.356 & 40.113 & 7 & 86.5 & 1.037 & 0.041 & 320.4 & 11.1 & 14.4 & 11.4 & 70.2 & 60.0 & 21.8 & 11.8 \\
\hline KG221 & 122.440 & 40.170 & 13 & 115 & 1.094 & 0.431 & 152.4 & 14.1 & 14.6 & 4.9 & 327.6 & 75.8 & 21.0 & 8.4 \\
\hline KG222 & 122.359 & 40.101 & 8 & 69.6 & 1.123 & 0.246 & 4.1 & 2.5 & 7.8 & 2.1 & 96.9 & 49.3 & 9.9 & 2.3 \\
\hline KG223 & 122.366 & 40.091 & 8 & 276 & 1.054 & 0.318 & 267.4 & 46.9 & 21.4 & 8.7 & 91.2 & 43.1 & 10.2 & 3.9 \\
\hline KG224 & 122.378 & 40.079 & 11 & 116 & 1.080 & 0.050 & 279.0 & 43.3 & 10.1 & 4.7 & 106.2 & 46.5 & 11.3 & 6.7 \\
\hline KG225 & 122.395 & 40.070 & 7 & 1240 & 1.158 & -0.027 & 164.6 & 28.8 & 12.9 & 2.2 & 314.1 & 57.5 & 12.9 & 3.2 \\
\hline
\end{tabular}




\begin{tabular}{|c|c|c|c|c|c|c|c|c|c|c|c|c|c|c|}
\hline KG226 & 122.411 & 40.060 & 13 & 757 & 1.106 & 0.463 & 177.5 & 28.9 & 44.4 & 9.4 & 58.9 & 41.0 & 14.6 & 6.6 \\
\hline $\mathrm{KG} 227$ & 122.420 & 40.056 & 10 & 11200 & 1.052 & 0.388 & 171.8 & 75.0 & 15.6 & 5.8 & 15.1 & 13.8 & 6.2 & 3.6 \\
\hline KG228 & 122.439 & 40.048 & 12 & 855 & 1.109 & 0.373 & 182.1 & 29.6 & 27.4 & 13.3 & 308.6 & 46.4 & 21.6 & 13.9 \\
\hline KG229 & 122.416 & 40.041 & 10 & 3190 & 1.326 & 0.412 & 155.9 & 22.9 & 24.9 & 8.9 & 38.5 & 47.4 & 18.5 & 3.4 \\
\hline KG230 & 122.383 & 40.041 & 10 & 1020 & 1.120 & 0.502 & 264.8 & 12.0 & 47.9 & 12.8 & 130.8 & 72.9 & 16.3 & 6.0 \\
\hline KG231 & 122.373 & 40.027 & 5 & 59 & 1.046 & 0.210 & 318.9 & 14.8 & 21.0 & 8.7 & 100.8 & 71.4 & 19.3 & 11.9 \\
\hline KG232 & 122.370 & 40.013 & 6 & 168 & 1.212 & 0.139 & 318.6 & 18.4 & 35.6 & 7.4 & 63.4 & 37.6 & 15.3 & 7.4 \\
\hline KG233 & 122.387 & 40.003 & 9 & 64.4 & 1.034 & 0.117 & 12.1 & 56.6 & 66.3 & 14.8 & 128.3 & 16.2 & 20.8 & 14.9 \\
\hline KG234 & 122.465 & 39.955 & 8 & 9210 & 1.150 & -0.299 & 113.3 & 3.4 & 4.9 & 3.9 & 307.4 & 86.5 & 6.9 & 4.8 \\
\hline KG235 & 122.402 & 39.938 & 11 & 435 & 1.103 & 0.685 & 204.5 & 34.6 & 15.3 & 6.7 & 39.1 & 54.6 & 7.0 & 5.6 \\
\hline KG236 & 122.397 & 39.938 & 8 & 255 & 1.196 & 0.433 & 170.2 & 36.9 & 8.7 & 4.7 & 47.3 & 35.9 & 7.7 & 5.7 \\
\hline KG237 & 122.385 & 39.943 & 9 & 1030 & 1.163 & 0.677 & 161.7 & 11.1 & 19.6 & 1.7 & 55.6 & 54.7 & 7.8 & 1.8 \\
\hline KG238 & 122.361 & 39.951 & 7 & 390 & 1.100 & 0.843 & 178.0 & 33.0 & 15.5 & 6.3 & 58.3 & 37.3 & 11.3 & 3.1 \\
\hline KG239 & 122.322 & 39.934 & 9 & 24100 & 1.245 & 0.461 & 274.8 & 38.1 & 13.9 & 4.9 & 57.4 & 45.4 & 6.3 & 3.5 \\
\hline $\mathrm{KG} 240$ & 122.302 & 39.965 & 8 & 9710 & 1.466 & -0.052 & 310.1 & 25.0 & 17.3 & 13.4 & 57.3 & 32.5 & 17.1 & 11.7 \\
\hline KG241 & 122.287 & 39.931 & 12 & 19500 & 1.244 & -0.232 & 280.2 & 42.8 & 11.2 & 4.7 & 13.6 & 3.7 & 15.4 & 6.6 \\
\hline $\mathrm{KG} 242$ & 122.290 & 39.942 & 7 & 8520 & 1.249 & -0.214 & 236.2 & 56.4 & 6.5 & 3.2 & 141.5 & 3.1 & 20.1 & 3.9 \\
\hline KG243 & 122.485 & 40.091 & 8 & 60.9 & 1.201 & 0.711 & 102.4 & 14.3 & 6.4 & 3.9 & 242.2 & 71.6 & 7.7 & 4.0 \\
\hline KG244 & 122.469 & 40.138 & 6 & 136 & 1.232 & 0.802 & 78.7 & 19.9 & 9.1 & 0.5 & 313.6 & 57.8 & 7.2 & 0.6 \\
\hline KG245 & 122.398 & 40.121 & 7 & 255 & 1.078 & 0.240 & 300.2 & 24.6 & 9.7 & 5.9 & 152.7 & 61.5 & 15.6 & 5.1 \\
\hline KG246 & 122.416 & 40.118 & 6 & 108 & 1.065 & 0.150 & 295.3 & 48.4 & 12.9 & 2.1 & 165.5 & 29.6 & 14.8 & 5.9 \\
\hline KG247 & 122.435 & 40.111 & 6 & 104 & 1.092 & 0.348 & 190.0 & 34.6 & 29.6 & 12.7 & 3.3 & 55.2 & 22.7 & 11.4 \\
\hline KG248 & 122.450 & 40.101 & 8 & 139 & 1.401 & 0.555 & 128.8 & 39.8 & 33.6 & 8.3 & 303.5 & 50.1 & 33.3 & 11.5 \\
\hline KG249 & 122.471 & 40.090 & 9 & 481 & 1.219 & 0.674 & 102.4 & 22.1 & 21.2 & 6.5 & 263.0 & 66.7 & 11.0 & 4.2 \\
\hline KG382 & 122.306 & 39.841 & 8 & 275 & 1.081 & 0.085 & 126.8 & 26.7 & 9.0 & 5.0 & 29.8 & 13.7 & 13.0 & 5.2 \\
\hline KG383 & 122.331 & 39.864 & 7 & 778 & 1.206 & 0.564 & 146.3 & 23.4 & 21.4 & 5.1 & 19.2 & 54.4 & 10.3 & 7.7 \\
\hline
\end{tabular}

Table 1 


\begin{tabular}{|c|c|c|c|c|c|c|c|c|c|c|c|c|c|c|}
\hline \multirow[t]{2}{*}{ Site } & \multicolumn{2}{|c|}{ Coordinates } & \multirow[t]{2}{*}{$\mathbf{n}$} & \multirow{2}{*}{$\frac{\mathbf{K m}}{\left(10^{-6} \mathrm{SI}\right)}$} & \multirow[t]{2}{*}{$\mathbf{P}_{\mathbf{j}}$} & \multirow[t]{2}{*}{$\mathbf{T}$} & \multicolumn{4}{|c|}{$\mathbf{K}_{1}$} & \multicolumn{4}{|c|}{$\mathbf{K}_{3}$} \\
\hline & $\begin{array}{l}\text { Latitude } \\
\left({ }^{\circ} \mathbf{N}\right)\end{array}$ & $\begin{array}{c}\text { Longitude } \\
\left({ }^{\circ} \mathbf{E}\right)\end{array}$ & & & & & $\mathbf{D}\left({ }^{\circ}\right)$ & $\mathbf{I}\left({ }^{\circ}\right)$ & $\boldsymbol{\alpha}_{95 \max }$ & $\alpha_{95 \min }$ & $\mathbf{D}\left(^{\circ}\right)$ & $\mathbf{I}\left({ }^{\circ}\right)$ & $\alpha_{95 \max }$ & $\alpha_{95 \min }$ \\
\hline KG368 & 122.368 & 39.823 & 9 & 4310 & 1.099 & 0.291 & 260.1 & 6.6 & 13.0 & 6.1 & 357.4 & 47.5 & 15.3 & 6.4 \\
\hline KG369 & 122.362 & 39.812 & 11 & 4840 & 1.094 & 0.030 & 263.4 & 12.0 & 10.0 & 4.5 & 123.7 & 74.4 & 13.2 & 4.3 \\
\hline KG370 & 122.358 & 39.802 & 12 & 8360 & 1.141 & 0.082 & 263.2 & 17.4 & 10.8 & 5.1 & 172.4 & 2.8 & 21.2 & 4.8 \\
\hline KG371 & 122.321 & 39.773 & 8 & 7120 & 1.266 & 0.249 & 257.2 & 46.1 & 6.5 & 4.1 & 120.3 & 35.1 & 6.1 & 3.8 \\
\hline KG372 & 122.315 & 39.756 & 9 & 5070 & 1.313 & 0.440 & 262.3 & 51.3 & 7.2 & 5.3 & 111.1 & 35.1 & 7.0 & 2.3 \\
\hline KG373 & 122.284 & 39.767 & 7 & 8920 & 1.451 & 0.226 & 210.6 & 61.9 & 10.8 & 2.9 & 303.0 & 1.3 & 5.5 & 2.4 \\
\hline KG374 & 122.296 & 39.770 & 9 & 4800 & 1.232 & 0.569 & 223.0 & 64.9 & 13.1 & 3.8 & 116.4 & 7.6 & 4.2 & 1.5 \\
\hline KG375 & 122.304 & 39.737 & 9 & 8910 & 1.132 & 0.263 & 206.3 & 43.0 & 8.7 & 1.1 & 102.0 & 14.8 & 2.4 & 1.1 \\
\hline KG376 & 122.324 & 39.729 & 9 & 2930 & 1.243 & 0.355 & 265.7 & 14.5 & 21.8 & 9.3 & 118.9 & 72.8 & 12.8 & 9.1 \\
\hline KG377 & 122.286 & 39.733 & 8 & 424 & 1.073 & 0.315 & 239.6 & 16.6 & 13.7 & 2.2 & 103.8 & 67.4 & 13.4 & 4.9 \\
\hline KG378 & 122.308 & 39.714 & 9 & 2460 & 1.181 & 0.095 & 208.0 & 25.3 & 15.0 & 10.0 & 95.9 & 38.6 & 28.2 & 10.8 \\
\hline KG379 & 122.278 & 39.753 & 8 & 4060 & 1.223 & 0.283 & 184.0 & 58.7 & 3.2 & 2.4 & 274.7 & 0.4 & 5.3 & 2.4 \\
\hline KG380 & 122.296 & 39.783 & 7 & 932 & 1.244 & 0.451 & 215.7 & 44.4 & 20.9 & 7.0 & 107.2 & 18.0 & 8.1 & 7.9 \\
\hline KG381 & 122.301 & 39.796 & 9 & 4310 & 1.174 & 0.091 & 232.5 & 32.2 & 14.3 & 5.0 & 88.8 & 52.0 & 11.5 & 3.4 \\
\hline KG384 & 122.273 & 39.802 & 7 & 3440 & 1.182 & 0.574 & 242.4 & 21.6 & 25.4 & 10.4 & 98.6 & 63.8 & 11.3 & 8.5 \\
\hline KG385 & 122.263 & 39.789 & 7 & 3810 & 1.214 & -0.328 & 211.1 & 19.8 & 16.3 & 4.8 & 77.7 & 62.4 & 22.2 & 4.1 \\
\hline KG386 & 122.232 & 39.766 & 9 & 3710 & 1.206 & 0.198 & 239.1 & 24.4 & 11.9 & 1.8 & 105.4 & 56.7 & 9.3 & 2.5 \\
\hline KG387 & 122.184 & 39.803 & 11 & 2400 & 1.160 & 0.451 & 215.0 & 55.6 & 21.4 & 4.7 & 317.8 & 8.6 & 17.8 & 5.2 \\
\hline KG388 & 122.125 & 39.768 & 8 & 1740 & 1.062 & 0.186 & 30.2 & 3.0 & 15.2 & 3.4 & 282.8 & 80.1 & 17.1 & 6.6 \\
\hline KG389 & 122.185 & 39.730 & 8 & 3410 & 1.132 & 0.201 & 283.7 & 65.9 & 7.8 & 3.6 & 90.3 & 23.5 & 6.6 & 1.9 \\
\hline KG390 & 122.148 & 39.725 & 7 & 267 & 1.095 & 0.595 & 238.5 & 50.9 & 26.5 & 4.3 & 96.8 & 32.5 & 10.7 & 5.0 \\
\hline KG391 & 122.177 & 39.694 & 6 & 3180 & 1.199 & 0.751 & 171.6 & 61.0 & 23.8 & 3.6 & 79.4 & 1.2 & 7.1 & 3.7 \\
\hline KG392 & 122.160 & 39.684 & 5 & 716 & 1.068 & 0.419 & 323.1 & 61.1 & 17.3 & 2.9 & 66.0 & 7.1 & 3.3 & 2.8 \\
\hline KG393 & 122.236 & 39.707 & 5 & 1010 & 1.084 & -0.163 & 352.6 & 57.1 & 7.4 & 1.1 & 240.1 & 13.9 & 16.2 & 3.3 \\
\hline KG394 & 122.253 & 39.688 & 8 & 5280 & 1.491 & 0.308 & 253.5 & 43.3 & 8.1 & 1.9 & 93.5 & 44.9 & 6.1 & 3.5 \\
\hline KG395 & 122.276 & 39.697 & 9 & 6610 & 1.200 & 0.131 & 248.0 & 43.0 & 33.3 & 8.5 & 90.3 & 44.8 & 12.6 & 7.1 \\
\hline KG396 & 122.288 & 39.657 & 10 & 3270 & 1.312 & 0.672 & 274.2 & 30.0 & 8.8 & 2.3 & 114.8 & 58.3 & 5.5 & 2.1 \\
\hline KG397 & 122.212 & 39.670 & 7 & 158 & 1.054 & 0.137 & 112.5 & 69.8 & 22.1 & 5.4 & 282.8 & 10.5 & 7.7 & 4.0 \\
\hline KG398 & 122.370 & 39.638 & 5 & 2100 & 1.215 & 0.715 & 92.4 & 16.0 & 57.8 & 5.2 & 318.1 & 67.7 & 12.7 & 8.4 \\
\hline KG399 & 122.360 & 39.649 & 10 & 6440 & 1.200 & 0.580 & 12.3 & 0.6 & 16.4 & 2.3 & 280.3 & 72.8 & 3.1 & 2.0 \\
\hline KG400 & 122.384 & 39.677 & 9 & 4790 & 1.111 & 0.099 & 82.1 & 8.4 & 12.4 & 6.5 & 196.9 & 70.5 & 12.6 & 6.5 \\
\hline KG401 & 122.398 & 39.705 & 9 & 3970 & 1.145 & 0.283 & 271.4 & 32.5 & 9.0 & 4.7 & 96.3 & 57.4 & 9.1 & 4.4 \\
\hline KG402 & 122.378 & 39.712 & 7 & 5740 & 1.090 & 0.185 & 98.3 & 0.5 & 10.4 & 4.6 & 189.5 & 66.1 & 8.4 & 3.2 \\
\hline KG403 & 122.384 & 39.826 & 9 & 11500 & 1.278 & -0.450 & 91.9 & 2.8 & 9.6 & 3.8 & 264.1 & 87.1 & 11.0 & 3.4 \\
\hline KG404 & 122.394 & 39.839 & 9 & 1430 & 1.225 & 0.489 & 166.6 & 39.6 & 6.3 & 2.2 & 337.3 & 50.0 & 13.1 & 2.1 \\
\hline KG405 & 122.394 & 39.825 & 8 & 9520 & 1.397 & -0.298 & 85.8 & 6.5 & 6.6 & 5.5 & 350.6 & 38.1 & 10.0 & 4.5 \\
\hline KG406 & 122.389 & 39.806 & 7 & 4120 & 1.248 & -0.703 & 267.3 & 7.6 & 9.6 & 4.0 & 8.7 & 56.0 & 33.6 & 3.4 \\
\hline KG407 & 122.433 & 39.793 & 6 & 541 & 1.064 & 0.404 & 91.4 & 37.9 & 50.6 & 11.0 & 320.7 & 40.0 & 17.9 & 8.7 \\
\hline KG408 & 122.403 & 39.780 & 11 & 6160 & 1.246 & 0.345 & 296.7 & 25.1 & 12.9 & 5.1 & 85.2 & 61.2 & 7.0 & 3.1 \\
\hline KG409 & 122.453 & 39.763 & 9 & 9420 & 1.219 & 0.361 & 100.3 & 14.2 & 8.9 & 4.4 & 238.3 & 71.2 & 7.2 & 4.7 \\
\hline KG410 & 122.397 & 39.743 & 6 & 1610 & 1.124 & 0.174 & 273.1 & 26.4 & 57.6 & 13.3 & 124.9 & 59.7 & 14.1 & 8.8 \\
\hline KG411 & 122.408 & 39.733 & 9 & 5180 & 1.151 & 0.292 & 275.5 & 36.6 & 16.6 & 3.3 & 116.2 & 51.6 & 15.0 & 3.6 \\
\hline KG412 & 122.478 & 39.800 & 9 & 4180 & 1.270 & -0.037 & 99.2 & 34.4 & 15.8 & 8.1 & 279.9 & 55.6 & 11.9 & 6.4 \\
\hline KG413 & 122.501 & 39.813 & 6 & 1100 & 1.266 & -0.402 & 329.8 & 23.6 & 19.5 & 9.9 & 183.6 & 62.3 & 39.9 & 6.8 \\
\hline KG414 & 122.512 & 39.820 & 7 & 7580 & 1.518 & -0.117 & 80.1 & 9.3 & 4.0 & 2.2 & 195.6 & 69.2 & 4.0 & 2.4 \\
\hline KG415 & 122.538 & 39.794 & 5 & 2230 & 1.436 & 0.198 & 275.4 & 7.2 & 12.2 & 5.2 & 174.2 & 56.9 & 13.2 & 4.6 \\
\hline KG416 & 122.522 & 39.785 & 9 & 4480 & 1.292 & -0.108 & 98.9 & 23.6 & 7.4 & 4.4 & 260.6 & 65.3 & 20.3 & 4.2 \\
\hline KG417 & 122.519 & 39.766 & 7 & 3980 & 1.221 & -0.303 & 114.2 & 24.5 & 7.8 & 2.9 & 277.4 & 64.5 & 11.9 & 4.1 \\
\hline KG418 & 122.556 & 39.738 & 8 & 1370 & 1.200 & -0.001 & 283.2 & 6.6 & 10.8 & 6.5 & 65.0 & 81.7 & 12.7 & 3.4 \\
\hline KG419 & 122.581 & 39.739 & 7 & 187 & 1.066 & 0.293 & 276.9 & 18.6 & 10.2 & 6.8 & 105.5 & 71.2 & 8.8 & 4.1 \\
\hline
\end{tabular}

Table 2 


\begin{tabular}{lcccccc}
\cline { 2 - 6 } & $\mathbf{C}_{\mathbf{1}}$ & $\mathbf{C}_{\mathbf{0}}$ & $\mathbf{a M}$ & $\mathbf{a m}$ & $\mathbf{d i r}$ & $\mathbf{m o d}$ \\
\hline $\begin{array}{l}\text { Gudaoling dome and Yinmawanshan pluton } \\
\text { Semi-variogram model }\end{array}$ & 1.2359 & 0.8272 & 95.7573 & 31.5501 & 334 & $\mathrm{~S}$ \\
\hline
\end{tabular}

$C_{1}:$ sill; $C_{0}$ : nugget effect; mod: adjusted model; aM: major amplitude (in kilometre); am: minor amplitude (in kilometre); dir: major amplitude direction (in degree); $S$ : spherical model

Table 3 


\begin{tabular}{|c|c|c|c|c|c|c|c|c|c|}
\hline Spot Analysis & $\begin{array}{l}\text { Isotopic } \\
\text { ratios }\end{array}$ & & & & & & & & $\begin{array}{c}\begin{array}{c}\text { Isotopic } \\
\text { ages }\end{array} \\
\end{array}$ \\
\hline & ${ }^{238} \mathrm{U} /{ }^{206} \mathrm{~Pb}$ & $1 \sigma$ & ${ }^{207} \mathrm{~Pb} /{ }^{206} \mathrm{~Pb}$ & $1 \sigma$ & ${ }^{207} \mathrm{~Pb} /{ }^{235} \mathrm{U}$ & $1 \sigma$ & ${ }^{206} \mathrm{~Pb} /{ }^{238} \mathrm{U}$ & $1 \sigma$ & ${ }^{206} \mathrm{~Pb} /{ }^{238} \mathrm{U}$ \\
\hline $09-114 / 2$ & 39.9840 & 0.8793 & 0.0499 & 0.0005 & 0.1720 & 0.0034 & 0.0250 & 0.0006 & $159 \pm 3$ \\
\hline $09-114 / 3$ & 40.4694 & 0.9008 & 0.0501 & 0.0005 & 0.1707 & 0.0035 & 0.0247 & 0.0006 & $157 \pm 3$ \\
\hline $09-114 / 4$ & 38.1098 & 0.9005 & 0.0519 & 0.0006 & 0.1878 & 0.0050 & 0.0262 & 0.0006 & $167 \pm 4$ \\
\hline $09-114 / 7$ & 42.4448 & 0.9188 & 0.0491 & 0.0005 & 0.1595 & 0.0027 & 0.0236 & 0.0005 & $150 \pm 3$ \\
\hline $09-114 / 8$ & 39.6983 & 0.8983 & 0.0506 & 0.0010 & 0.1759 & 0.0059 & 0.0252 & 0.0006 & $160 \pm 4$ \\
\hline $09-114 / 11$ & 41.5800 & 0.8817 & 0.0490 & 0.0005 & 0.1626 & 0.0024 & 0.0241 & 0.0005 & $153 \pm 3$ \\
\hline $09-114 / 16$ & 41.2882 & 0.8865 & 0.0493 & 0.0005 & 0.1644 & 0.0025 & 0.0242 & 0.0005 & $154 \pm 3$ \\
\hline $09-114 / 17$ & 40.0641 & 0.8507 & 0.0492 & 0.0005 & 0.1691 & 0.0024 & 0.0250 & 0.0005 & $159 \pm 3$ \\
\hline
\end{tabular}

Table 4 